Maurer School of Law: Indiana University

Digital Repository @ Maurer Law

1991

\title{
The Perils of Unreasonable Risk: Information, Regulatory Policy, and Toxic Substances Control
}

John S. Applegate

Indiana University Maurer School of Law, jsapple@indiana.edu

Follow this and additional works at: https://www.repository.law.indiana.edu/facpub

Part of the Environmental Law Commons, and the Environmental Policy Commons

\section{Recommended Citation}

Applegate, John S., "The Perils of Unreasonable Risk: Information, Regulatory Policy, and Toxic Substances Control" (1991). Articles by Maurer Faculty. 719.

https://www.repository.law.indiana.edu/facpub/719

This Article is brought to you for free and open access by the Faculty Scholarship at Digital Repository @ Maurer Law. It has been accepted for inclusion in Articles by Maurer Faculty by an authorized administrator of Digital Repository @ Maurer Law. For more information, please contactrvaughan@indiana.edu. 


\title{
THE PERILS OF UNREASONABLE RISK: INFORMATION, REGULATORY POLICY, AND TOXIC SUBSTANCES CONTROL
}

\author{
John S. Applegate*
}

\section{INTRODUCTION}

The availability of relevant information is essential to all economic activity. Without knowing price, cost, quality, availability, and the like, economic actors cannot make the rational decisions upon which market efficiency depends. Indeed, perfect information is a basic assumption of most microeconomic models. Yet information is not costless, and its acquisition is usually regarded as one of the principal transaction costs in a market economy. Lack of information is a market imperfection that distorts otherwise efficient outcomes.

Much government regulation attempts to correct this imperfection by gathering and disseminating information that otherwise would not be available to market actors at all or at a reasonable price. ${ }^{1}$ For regulation whose principal purpose is direct control of certain activities, on the other hand, information is a transaction cost of the regulatory scheme itself. Regulation of toxic substances-the subject of this Article-does not involve the gathering or dissemination of health or cost information for the purpose of perfecting a market in pollution. ${ }^{2}$ Rather, it seeks to achieve a healthful environment at an affordable cost through direct controls on the use and disposal of chemical substances. Information remains the sine qua non of the rational development of specific regulatory commands regarding hazardous chemicals. Thus, a regulatory agency like the United States Environmental Protection Agency (EPA) must gather, develop, and analyze relevant information about the activities that it wishes to regulate, and about available control techniques, before it can address the ultimate task of implementing the statutory trade-off between safety and cost.

* Associate Professor of Law, University of Cincinnati. B.A., 1978, Haverford College; J.D., 1981, Harvard University.

I wish to thank Joseph Tomain and William Lovett for helpful comments on earlier versions of this Article. Lisa Stamm, Elizabeth Mason, and Joy Rostoker provided valuable research assistance. I also thank the University of Cincinnati College of Law Center for the Study of Dispute Resolution for financial assistance under a grant from the Ohio Hazardous Substance Research, Education and Management Institute. This Article is dedicated to the memory of my father-in-law, George M. Grossman.

I. The disclosure requirements in connection with the sale of securities exemplify market-perfecting regulation. See I5 U.S.C. $\$ 77 j$ (I988).

2. This is due in part to the impossibility of such an endeavor. Critical failures in the market for toxic substances, including lack of information, preclude even a minimally functional market. See P. Asch, Consumer Safety Regulation: Putting a Price on Life and Limb 43-59 (1988); see also infra text accompanying notes 186-207 (discussing rationales for right-to-know laws). 
Information acquisition is a particularly difficult problem for the regulation of toxic-usually meaning carcinogenic-substances. ${ }^{3}$ To paraphrase Casablanca, the information needs of toxic substances regulation are like other regulatory information needs, only more so. Science does not know all of tbe health effects of these chemicals because the effects can occur at low doses and appear after long periods of time. In addition, science does not fully understand the mechanism of carcinogenicity. Consequently, data acquisition and analysis comprise the lion's share of the regulatory effort. Legal consideration of toxic substances regulation, however, has concentrated primarily on the best ways to regulate when uncertainty predominates ${ }^{4}$ and on the best institutional arrangements for making risk decisions. ${ }^{5}$ Only recently have legal commentators begun to consider in detail ways in which regulatory structures might narrow the data gap for toxic substances. ${ }^{6}$ It is

3. This Article uses the terms "toxic substances" and "toxic chemicals" interchangeably to refer to chemical substances, typically manufactured, that have long-term deleterious effects on human health. Carcinogenicity (the induction of cancer) is most commonly used to measure toxicity because it is a sensitive indicator of toxicity at low levels of exposure and also because cancer is a major source of anxiety for the American public. See generally Merrill, Regulation of Toxic Chemicals (Book Review), 58 Tex. L. Rev. 463, 463-68 (1980) (reviewing M. Shapo, A Nation of Guinea Pigs (1979)) (observing increasing public concern with, and governmental reaction to, environmentally induced cancer).

4. See, e.g., Gaines, Science, Politics, and the Management of Toxic Risks Through Law, 30 Jurimetrics J. 271 (1990); Huber, The Old-New Division in Risk Regulation, 69 Va. L. Rev. 1025 (1983). Professor Latin has explored many aspects of uncertainty in a series of important articles. See Latin, The Feasibility of Occupational Health Standards: An Essay on Legal Decisionmaking Under Uncertainty, 78 Nw. U.L. Rev. 583 (1983) [hereinafter Latin, Feasibility]; Latin, Good Science, Bad Regulation, and Toxic Risk Assessment, 5 Yale J. on Reg. 89 (1988) [hereinafter Latin, Good Science]; Latin, Ideal Versus Real Regulatory Efficiency: Implementation of Uniform Standards and "Fine-Tuning" Regulatory Reforms, 37 Stan. L. Rev. 1267 (1985) [hereinafter Latin, Regulatory Efficiency]; Latin, The "Siguificance" of Toxic Health Risks: An Essay on Legal Decisionmaking Under Uncertainty, 10 Ecology L.Q. 339 (1982) [hereinafter Latin, Toxic Health Risks].

5. See, e.g., Elliott, Goal Analysis Versus Institutional Analysis of Toxic Compensation Systems, 73 Geo. L.J. 1357 (1985) [hereinafter Elliott, Goal Analysis]; Elliott, Why Courts?: Comment on Robinson, 14 J. Legal Stud. 799 (1985); Latin, Environmental Deregulation and Consumer Decisionmaking Under Uncertainty, 6 Harv. Envtl. L. Rev. 187 (1982) [hereinafter Latin, Consumer Decisionmaking]; Schroeder \& Shapiro, Responses to Occupational Disease: The Role of Markets, Regulation, and Information, 72 Geo. L.J. 1231 (1984); see also Gillette \& Krier, Risk, Courts, and Agencies, $138 \mathrm{U}$. Pa. L. Rev. 1027, 1032-36 (1990) (distinguishing between attitudes toward risk and institutional issues); Huber, Safety and the Second Best: The Hazards of Public Risk Management in the Courts, 85 Colum. L. Rev. 277, 280-305 (1985) (reviewing the two sets of attitudes).

6. See Lyndon, Information Economics and Chemical Toxicity: Desiguing Laws to Produce and Use Data, 87 Mich. L. Rev. 1795 (1989) [hereinafter Lyndon, Information Economics]; Lyndon, Risk Assessment, Risk Communication and Legitimacy: An Introduction to the Symposium, 14 Colum. J. Envtl. L. 289, 289 n.l (1989) [hereinafter Lyndon, Risk Assessment]. The government has also been concerned about this problem. See, e.g., National Academy of Sciences, Decision Making for Regulating 
the latter area with which this Article is concerned.

Part I of the Article briefly describes the sources of the toxic substances data gap and its effect on regulatory policy. Part II is a detailed analysis of the information demands of the regulatory structures for toxic substances control. Current regulatory policy has adopted a standard of unreasonable risk and an analytical methodology known as quantitative risk assessment, both of which require enormous amounts of information and stretch the gap between available and needed data. Moreover, other parts of the regulatory process impose substantial information demands in addition to those imposed by the unreasonable risk standard. It is therefore important to examine and improve datagathering mechanisms.

Part III turns to the statutory techniques available to EPA for generating information. It evaluates these techniques under a number of criteria and finds them useful, but of limited use in developing new data. Part IV considers the provisions of the Federal Insecticide, Fungicide, and Rodenticide Act (FIFRA) ${ }^{7}$ and the Toxic Substances Control Act (TSCA) ${ }^{8}$ that authorize EPA to require the chemical and pesticide industries to undertake toxicological and other testing of their products. The FIFRA and TSCA requirements to test have most of the advantages and few of the limitations of the other statutory datagenerating techniques. FIFRA, however, is limited to pesticides. TSCA has been largely ignored by legal commentators, probably because its major contribution to toxics regulation is not control techniques but the establishment of regulatory mechanisms to fill the data gap. ${ }^{9}$ This Article suggests that TSCA test rules have the potential to be extraordinarily useful in an overall information development policy for toxic substances. It concludes with several suggestions for improvements in the TSCA test rule standard and procedure, which would give test rules the coverage and flexibility needed to meet that potential.

Chemicals in the Environment (1975) [hereinafter Decision Making]; National Academy of Sciences, Principles for Evaluating Chemicals in the Environment (1975) [hereinafter Principles for Evaluating Chemicals in the Environment]; National Academy of Sciences, Toxicity Testing: Strategies to Determine Needs and Priorities (1984) [hereinafter Toxicity Testing].

7. 7 U.S.C. $\$ \$ 136-136 y$ (1988).

8. 15 U.S.C. $\S \S 2601-2629$ (1988).

9. Professor Weinstein's study of decision making focuses on TSCA because TSCA serves the information function of regulation. See Weinstein, Decision Making for Toxic Substances Control: Cost-Effective Information Development for the Control of Environmental Carcinogens, 27 Pub. Pol'y 333, 334-35 (1979). Among legal commentators, David Hayes has been something of a voice crying in the wilderness that TSCA's information acquisition provisions should be the keystone of toxic substances regulation. See Hayes, The Potential for New Life in an "Old" Statute: The Toxic Substances Control Act in Its 13th Year, 13 Chem. Reg. Rep. (BNA) 57, 58-59 (Apr. 21, 1989) [hereinafter Hayes, New Life]; Hayes, TSCA: The Sleeping Giant is Stirring, Nat. Resources \& Env't, Winter 1990, at 3 [hereinafter Hayes, Sleeping Giant]. 


\section{Toxic Substances and Uncertainty in the Regulatory Process}

Several characteristics shared by all toxic substances render extremely difficult the detection of toxic effects (primarily cancer), the assessment of their severity, and the understanding of how and to whom the effects occur. ${ }^{10}$ Exposure to these chemicals tends to be chronic, at low doses, and consequently to occur without the individual's awareness of exposure. There is typically a long latency period between exposure and the appearance of health effects. The effects are rare and may be characterized as "nonsignature" diseases."1 In other words, not everyone exposed to a toxic chemical will become sick, and those who do may not be aware that the illness results from the exposure. In addition, it may be impossible to reconstruct which chemical (if any) caused the illness or when the exposure occurred.

These characteristics are the result of the unique and still largely mysterious disease mechanism of cancer. It is not well understood why a particular cell becomes cancerous or how exposure to a chemical substance might be involved. The lack of understanding at the molecular level makes it difficult to establish a completely safe threshold level of exposure to a carcinogen, that is, a nonzero level of exposure that can confidently be predicted to produce no adverse health effects. One plausible theory of carcinogenesis, for example, is that cancer can be initiated by one "hit" by a single molecule of a chemical on a single cell. ${ }^{12}$ If cancer can be caused at the molecular level in this way, there is no basis for believing that the cancer initiation mechanism deactivates below some particular number of molecules to which the cell is

10. The following discussion of the nature and characteristics of toxic substances is taken from the extensive literature on the subject. See Brennan, Causal Chains and Statistical Links: The Role of Scientific Uncertainty in Hazardous-Substance Litigation, 73 Cornell L. Rev. 469, 501-09 (1988); Doniger, Federal Regulation of Vinyl Chloride: A Short Course in the Law and Policy of Toxic Substances Control, 7 Ecology L.Q, 500, 514-20 (1978); Interagency Regulatory Liaison Group (1RLG), Scientific Bases for Identification of Potential Carcinogens and Estimation of Risk; Request for Comments on Report, 44 Fed. Reg. 39,858, 39,860-61 (1979) [hereinafter Scientific Bases]; Leape, Quantitative Risk Assessment in Regulation of Environmental Carcinogens, 4 Harv. Envtl. L. Rev. 86, 90-97 (1980); Page, A Generic View of Toxic Chemicals and Similar Risks, 7 Ecology L.Q. 207, 208-16 (1978).

The traditional assumption was that toxics were a subset of pollutants and chemicals generally. See R. Melnick, Regulation and the Courts: The Case of the Clean Air Act 243-49 (1983). However, new capacity to detect ever smaller concentrations of chemicals, see Merrill, FDA's Implementation of the Delaney Clause: Repudiation of Congressional Choice or Reasoned Adaptation to Scientific Progress?, 5 Yale J. on Reg. 1, 13-15 (1988), and more sophisticated test methods suggest that all or most pollutants have no threshold, see $R$. Melnick, supra, at 356.

11. Nonsignature diseases are those "that can be caused by exposure to a variety of substances." Abraham \& Merrill, Scientific Uncertainty in the Courts, Issues Sci. \& Tech., Winter 1986, at 93, 104.

12. See Anderson, Scientific Developments in Risk Assessment: Legal Implications, 14 Colum. J. Envtl. L. 411, 417-18 (1989) (noting also that one-hit hypothesis is not the only plausible theory). 
exposed, even though the statistical likelihood of cancer's initiation is reduced. In addition to the theoretical difficulty of determining "safe" levels of exposure, long latency and rarity of effect mean that experimental findings of no observed effect are unreliable. ${ }^{13}$ Instead, the best that can be done to determine the effects of toxic substances is to estimate risk, defined conventionally as the gravity of the expected loss discounted by its probability. ${ }^{14}$ As a result, a fundamental characteristic of what might be called the statistical concept of toxicity is that toxic potency is not measured in the layperson's terms of the seriousness of the effects (the gravity of cancer is given) or of the speed with which disease or death occurs. Rather, scientists and regulators measure toxicity in terms of the number of excess cancer cases that are likely to be induced by exposure to the substance.

The prediction of excess deaths for regulatory purposes is, as we shall see, an extremely information-intensive undertaking for which sufficient data is rarely available. ${ }^{15}$ The result is pervasive uncertainty in the regulatory process. ${ }^{16}$ The regulatory effect of uncertainty is, as in market transactions, inefficiency. The agency simply does not know where to allocate resources or how much to allocate. Lacking necessary information, the regulator cannot be certain what the problems are, which problems are most pressing, what regulatory goals to set, how best to achieve them, or even when they have been achieved.

An information-starved regulatory regime is inefficient whether it errs on the side of overregulation by placing the burden of proof on industry, or on the side of underregulation by placing the burden of proof on the agency. The dangers of inefficiency are most often raised in relation to the former. Overregulation, it is argued, depresses industrial output below efficient levels by artificially raising the cost of the overregulated goods or services. When industry cannot prove the safety of a product, the product is subjected to regulatory burdens that may be unwarranted by its actual characteristics. The costs of achieving a cleaner environment, in this view, may outweigh the social benefits of requiring proof of product safety. ${ }^{17}$

The legal effects of uncertainty are at least as troubling when the agency has the burden of proof. If it is the agency's obligation to justify

13. This phenomenon is known as the false negative. See Page, supra note 10 , at 231-37; cf. Reserve Mining Co. v. EPA, 514 F.2d 492, 515 (8th Cir. 1975) (en banc) (unanimous decision) (finding that absence of observed effect of asbestos in drinking water did not eliminate basis for concern about possible effect), modified sub nom. Reserve Mining Co. v. Lord, 529 F.2d 181 (8th Cir. 1976).

14. See Gillette \& Krier, supra note 5 , at $1028 \mathrm{n} .1$ (distinguishing different meanings of "risk"); Stenzel, A Proposal for a National Risk Assessment Clearinghouse, 14 Colum. J. Envtl. L. 549, 549 n.1 (1989) (same).

15. See infra notes $124-152$ and accompanying text.

16. See sources cited supra note 4 .

17. See Luken \& Clark, How Efficient Are EPA's Regulations?, 20 Envtl. L. Rep. (Envtl. L. lnst.) 10,419, 10,419-20 (1990). 
its actions, uncertainty undermines the factual support it needs to withstand challenges from affected industries. Subjecting agency action to an intensive standard of judicial review, for example, increases the likelihood that a court will find the agency's justification wanting. Similarly, demands for particular types of supporting evidence, or for a high degree of scientific acceptance of the agency's conclusions, can place nearly impossible burdens on an agency operating under conditions of uncertainty. ${ }^{18}$ The result is that agencies undertake less regulation, not because they have made a judgment that regulatory action is unnecessary, but because they cannot afford the high costs of developing a record that will be fairly certain to withstand judicial review. ${ }^{19}$

To avoid these difficulties, agencies must develop a certain expertise in the characteristics and effects of toxic substances. However, at some point the time and expense of gathering additional information outweighs its utility. This Article does not attempt to locate that point. ${ }^{20}$ Instead, it proceeds on the basis that not all uncertainty is "intractable"21 and that most uncertainty results from the difficulty of learning about toxic substances with limited resources. Therefore, even if additional information will never eliminate uncertainty, it can usefully reduce uncertainty and improve agency decision making.

18. See Latin, Toxic Health Risks, supra note 4, at 357-58.

19. See infra notes 109,377 and accompanying text.

20. Not surprisingly, opinion varies greatly over when that point is reached. A recent exchange on this topic may be found in Latin, Regulatory Efficiency, supra note 4, at 1304 (contending that overemphasis on precision in regulation results in inadequate, albeit second-best, regulatory response), and Ackerman \& Stewart, Reforming Environmental Law, 37 Stan. L. Rev. 1333, 1355-57 (1985) (agreeing that perfect precision is impossible but arguing that acquiring more information allows decision makers to make guesses "as openly and intelligently as possible"). Professor McGarity has provided a useful set of factors for deciding when to stop seeking additional information. McGarity, Substantive and Procedural Discretion in Administrative Resolution of Science Policy Questions: Regulating Carcinogens in EPA and OSHA, 67 Geo. L.J. 729, 737-38 (1979); see also Schwartz, Products Liability, Corporate Structure, and Bankruptcy: Toxic Substances and the Remote Risk Relationship, $14 \mathrm{~J}$. Legal Stud. 689, 695-703 (1985) (developing model for determining how much additional research is economically justified). This Article operates within the area, however defined, where additional research would prove worthwhile.

A number of commentators have also distinguished between scientific information that is ultimately discoverable, information that is not, and information that is simply too expensive to be worthwhile. See Gelpe \& Tarlock, The Uses of Scientific Information in Environmental Decisionmaking, 48 S. Cal. L. Rev. 371, 392-96 (1974) (distinguishing "categories and subcategories of ecological information" by availability, definiteness, and practical and theoretical obtainability); Latin, Toxic Health Risks, supra note 4, at 356-58 (distinguishing knowledge uncertainty and information uncertainty); McGarity, supra, at 732-47 (distinguishing trans-scientific issues, insufficient data, varying interpretations, and disagreement over inferences).

21. Lyndon, Information Economics, supra note 6, at 1797. 


\section{The lnformation Needs of Toxics Regulation}

In general, the information needs of an agency like EPA can be assigned to four regnlatory functions: identifying and defining the hazards thought to require a regulatory response; setting regulatory priorities among identified hazards; deciding upon appropriate responses, i.e., what we normally call "regulation"; and enforcement of the chosen responses. ${ }^{22}$ The choice and implementation of the standard used to decide upon the regulatory response to an identified toxic hazard has the largest single impact on regulatory needs for information. Hence it will be treated at greatest length. Choosing the appropriate regulatory response requires EPA to consider health effects, technology, and cost. It is easy to fignre out that drinking a glass of gasoline is toxicologically unwise, but it is extremely difficult to determine how many (if any) parts per million of gasoline may be safely inhaled while filling up at the pump. The agency must also ask which regulatory responses are likely to be effective, what degree of improvement each is likely to accomplish, which technologies are available, and what the improvement will cost. ${ }^{23}$ The statutes that regulate toxic substances have established a standard-unreasonable risk-and EPA has adopted a methodology-quantitative risk assessment-for implementation of that standard, both of which are highly information-intensive.

\section{A. The Unreasonable Risk Standard}

EPA is empowered to regulate the "life cycle" of toxic chemicals through four major statutes: FIFRA, ${ }^{24}$ TSCA,${ }^{25}$ the Resource Conser-

22. The following discussion concerns primarily the development and application of relatively broad regulatory rules. Agencies often engage in licensing of individual products. Licensing involves similar informational requirements, but the agency does not initiate action and must review all products or activities presented to it. If the agency is to avoid completely ad hoc licensing decisions, however, it must apply standard approaches, which would be developed more or less as described here. See generally S. Breyer, Regulation and Its Reform 96-1 I9, I31-55 (1982) (describing standard setting and individualized screening processes).

23. For the purposes of setting priorities and determining regulatory responses, this Article treats as axiomatic that the regulatory system should be cost-effective. As a general proposition, an agency should try to achieve the maximum risk reduction possible with the finite resources available to it. See Principles for Evaluating Chemicals in the Environment, supra note 6, at I9-20; Weinstein, supra note 9, at 337-39; see also Shapiro \& McGarity, Reorienting OSHA: Regulatory Alteruatives and Legislative Reform, 6 Yale J. on Reg. 1, 3 (1989) (attributing OSHA's inaction in part to failure to establish regulatory priorities). However, this use of risk-cost-benefit balancing as a tool of decision making need not be pressed into service as the regulatory goal as well. See Sagoff, Where Ickes Went Right, or Reason and Rationality in Environmental Law, 14 Ecology L.Q. 265, 297, 302, 317 (1987). That is, the axiom of cost-effectiveness applies to the agency's allocation of limited funds in pursuit of its pre-existing environmental goals, but it does not necessarily apply to defining the goals themselves.

24. 7 U.S.C. $\S \S 136-136 y$ (1988).

25. 15 U.S.C. $\S \S 2601-2629$ (1988). 
vation and Recovery Act (RCRA), ${ }^{26}$ and the Comprehensive Environmental Response, Compensation, and Liability Act (CERCLA or Superfund). ${ }^{27}$ In each of these statutes, Congress has established regulatory standards only in the most general terms, leaving it to EPA to quantify them in rules of general applicability or through licensing proceedings. Although the statutes are phrased in different ways and use different regulatory structures, all adopt a standard that can generically be called unreasonable risk. "Unreasonable" describes an undefined, nonzero level of risk determined on an ad hoc basis by balancing both health considerations and nonhealth concerns such as technology, feasibility, and cost. ${ }^{28}$

1. The Statutes. - Under FIFRA, all pesticides must be registered with EPA, which must approve the pesticides for their intended uses based on EPA's evaluation of the risks they pose to human health and the environment. ${ }^{29}$ The registrant has the initial and continuing burden of proving that the pesticide meets the registration requirements. ${ }^{30}$ If at some later time it appears that the registration can no longer be

26. 42 U.S.C. $\S \S 6901-6987$ (1988).

27. Id. $\S \S 9601-9675$.

This Article will consider only incidentally the Clean Air Act, 42 U.S.C. $\S \S 7401-7642$ (1988), and the Clean Water Act, 33 U.S.C. $\S \S 1251-1387$ (1988), because toxics are a relatively small part of their mandates and because both use regulatory standards that are different in several respects from those of the toxics statutes. See Natural Resources Defense Council, Inc. v. EPA (the Vinyl Chloride case), 824 F.2d 1146, $1163-65$ (D.C. Cir. 1987) (en banc) (interpreting Clean Air Act, 42 U.S.C. § 7412(b)(1)(B) (1982)); Hercules, Inc. v. EPA, 598 F.2d 91, 110-14 (D.C. Cir. 1978) (interpreting Clean Water Act, 33 U.S.C. § 1317(a) (1976)). This Article also excludes from direct consideration the toxics provisions of the Federal Food, Drug, and Cosmetic Act, 21 U.S.C. \& 348(c)(3)(A) (1988) (the Delaney Clause), the Occupational Safety and Health Act, 29 U.S.C. $\S 655(b)(5)$ (1988), and the Consumer Product Safety Act, 15 U.S.C. § 2056(a) (1988), for similar reasons.

28. Other regulatory standards are, of course, entirely possible and are used. For toxic substances, a frequently cited alternative is technology-based control. See Gaines, supra note 4, at 299-303. A technology-based system would set levels based not on health effects, but on the control capacity of current or expected technology. Alternatively, the agency could simply mandate use of a particular technology or process. Technology-based systems are often advocated as less information intensive. See McGarity, Media-Quality, Technology, and Cost-Benefit Balancing Strategies for Health and Environmental Regulation, Law \& Contemp. Probs., Summer 1983, at 159, 206-08. But see Gaines, supra note 4, at 300-03 (expressing doubts about advantages of technologybased system). EPA is currently experimenting with technology-based standards for land disposal of hazardous waste. See EPA, Hazardous Waste Management System: Land Disposal Restrictions, 55 Fed. Reg. 6640 (1990); Hazardous Waste Treatment Council v. EPA, 886 F.2d 355, 361 (D.C. Cir. 1989) (approving plan in principle), cert. denied, $111 \mathrm{~S}$. Ct. 139 (1990). In addition, Congress adopted a partially technologybased system for air toxics in the Clean Air Act Amendments of 1990, Pub. L. No. 101549, § 301, 104 Stat. 2399, 2531 (1990) (to be codified at 42 U.S.C § 7412(d)).

29. 7 U.S.C. § $136 \mathrm{a}(\mathrm{a})$, (c)(5) (1988).

30. See Environmental Defense Fund, Inc. v. EPA, 465 F.2d 528, 532 (D.C. Cir. 1972). However, when EPA decides to disapprove a pesticide, it has the burden of initial production and of supporting its ultimate decision by substantial evidence. See 
supported, EPA may cancel it. ${ }^{31}$ The lodestar of approval and cancellation decisions is whether the pesticide will have "unreasonable adverse effects on the environment," 32 a standard that is defined as an "unreasonable risk ... taking into account the economic, social, and environmental costs and benefits of [the pesticide's] use."33 Congress wanted EPA to achieve the "wise control [of pesticides] based on a careful balancing of benefit versus risk." 34

TSCA was designed to provide comprehensive regulation of chemicals that previously had been controlled piecemeal under the pollution laws. ${ }^{35}$ It also contains a wide variety of information-gathering provisions to enable EPA to assemble the data necessary to identify the need for regulatory action in the first place, and to help EPA choose among its many regnlatory options. ${ }^{36} \mathrm{EPA}$ must undertake regulatory action if it finds that use of a chemical "presents or will present an unreasonable risk of injury to [human] health or the environment."37 Congress deliberately chose not to define "unreasonable risk," but the legislative history makes it clear that it depends on a case-by-case consideration of the severity and likelihood of harm as against the benefits of the chemical, but does not include de minimis risks. ${ }^{38}$

RCRA requires EPA to identify and list "hazardous waste," which is broadly defined as waste that may cause serious illness or "pose a substantial present or potential hazard to human health or the environment."39 Listing is a prerequisite for substantive regulation of waste generation, transportation, storage, and disposal under the standard "as may be necessary to protect human health and the environment."40 The listing decision may be based either on the potency of the chemical (toxicity) and on the degree to which humans are exposed to it, or on the basis of potency alone in appropriate cases. ${ }^{41}$ There is language in

National Coalition Against the Misuse of Pesticides v. EPA, 867 F.2d 636, 642 (D.C. Cir. 1989).

31. 7 U.S.C. $\$ 136$ d(b) (1988); see also Environmental Defense Fund, Inc. v. EPA, 465 F.2d at 532. EPA may suspend registration under an accelerated schedule if it finds that the pesticide presents an imminent hazard. 7 U.S.C. $\$ 136 \mathrm{~d}(\mathrm{c})$; see also $465 \mathrm{~F} .2 \mathrm{~d}$ at 533 (holding that notice of intent to cancel creates presumption that suspension is necessary as well).

32. 7 U.S.C. $\S 136 \mathrm{a}(\mathrm{c})(5)(\mathrm{C}),(\mathrm{D})$ (1988) (registration); id. § 136d(b) (cancellation).

33. Id. § 136(bb).

34. S. Rep. No. 838, 92 d Cong., $2 d$ Sess. 4 (1972).

35. See H.R. Rep. No. 1341, 94th Cong., 2d Sess. 6-7 (1976).

36. See infra text accompanying notes 291-293.

37. 15 U.S.C. § 2605(a) (1988).

38. H.R. Rep. No. 1341, supra note 35, at 13-14. EPA is to look broadly for risks and benefits. H.R. Conf. Rep. No. 1679, 94th Cong., 2d Sess. 60-61, reprinted in 1976 U.S. Code Cong. \& Admin. News 4539, 4545-46.

39. 42 U.S.C. $\S 6903(5)$ (1988).

40. Id. $\S 6922(a)$; see id. $\S \S 6922-6925$ (standard setting for generation and storage and permit issuing for storage and disposal).

41. Id. § 6921(b)(1); 40 C.F.R. § 261.11(a) (1990). 
the legislative history of the 1984 RCRA amendments to indicate that cost is not an appropriate consideration in developing standards for storing and disposing of wastes; ${ }^{42}$ however, the original definition of "hazardous waste," unchanged in 1984, was described as intended "reasonably [to] protect" health, ${ }^{43}$ and the 1984 amendments clearly contemplate a nonzero level of post-regulation risk. ${ }^{44}$

Like RCRA, CERCLA is comprehensive with respect to the substances to which it applies. The basic CERCLA process, as amended by the Superfund Amendments and Reauthorization Act of 1986 (SARA), ${ }^{45}$ is straightforward: hazardous chemicals are identified by statute or EPA action; ${ }^{46}$ cleanup sites are identified and targeted for cleanup through the National Priority List (NPL);47 a "remedial investigation or feasibility study" (RI/FS) is undertaken to assess the nature and extent of the problem;48 cleanup measures ("response authorities") are chosen and implemented in accordance with the National Contingency Plan (NCP);49 and response costs are funded if necessary by the Superfund itself and then recovered from the "responsible parties" identified by the statute.50 The list of chemicals targeted by CERCLA is drawn initially from other statutes, ${ }^{51}$ but EPA may add chemicals "which, when released into the environment may present

42. See H.R. Rep. No. 198, 98th Cong., 2d Sess., pt. 1, at 63, reprinted in 1984 U.S. Code Cong. \& Admin. News 5576, 5622; H.R. Conf. Rep. No. 1133, 98th Cong., 2d Sess. 81, reprinted in 1984 U.S. Code Cong. \& Admin. News 5649, 5651-52.

43. H.R. Rep. No. 1491, 94th Cong., 2d Sess., pt. 1, at 28, 57, reprinted in 1976 U.S. Code Cong. \& Admin. News 6238, 6266, 6295 (emphasis added). The use of "reasonably" is particularly interesting because RCRA was passed in the same year as TSCA, and TSCA used "unreasonable risk" to indicate cost-risk-benefit balancing. See supra note 38 .

The Supreme Court subsequently interpreted language like this to mean not risk free. Industrial Union Dep't, AFL-ClO v. American Petroleum Inst. (the Benzene case), 448 U.S. 607,642 (I980) (plurality).

44. RCRA requires pretreatment of certain hazardous wastes "so that short-term and long-term threats to human health and the environment are minimized." 42 U.S.C. $\S 6924(\mathrm{~m})$ (1988). The D.C. Circuit has interpreted this provision to permit standards that do not completely eliminate health risks and that are based on the best available technology. See Hazardous Waste Treatment Council v. EPA, 886 F.2d 355, 361 (D.C. Cir. 1989), cert. denied, 111 S. Ct. 139 (1990). EPA's proposed corrective action regulations, promulgated under 42 U.S.C. $\$ 6924(u)$, interpret "necessary to protect human health," id. $\$ 6925(\mathrm{c})(3)$, to permit a residual risk ranging from 1 in 10,000 to 1 in $1,000,000$. See EPA, Corrective Action for Solid Waste Management Units (SWMUs) at Hazardous Waste Management Facilities, 55 Fed. Reg. 30,798, 30,804, 30,878 (1990) (to be codified at 40 C.F.R. $\$ 264.525$ (d)(1)(ii)(A)) (proposed July 27, 1990).

45. Pub. L. No. 99-499, 100 Stat. 1613 (1986).

46. 42 U.S.C. $\S \S 9601(14), 9602$ (1988).

47. Id. $\$ 9605(a)(8)$.

48. Id. § 9604(a).

49. Id. (response authorities); id. § 9605(a) (NCP).

50. Id. $\S 9607$ (liability of responsible parties); id. $\$ \S 9611-9612$ (use of the Superfund).

51. Id. § 960I(14); see also id. \$9601(33) (defining “pollutant or contaminant"). 
substantial danger to the public health or welfare or the environment."52 EPA also may establish and revise quantities of each chemical that must be reported if released into the environment. ${ }^{53}$ ln cleaning up an NPL site, CERCLA requires the agency to "select a remedial action that is protective of human health and the environment, that is cost effective, and that utilizes permanent solutions . . . to the maximum extent practicable."54 EPA must achieve a degree of cleanup that "assures protection of human health and the environment." 55 This is not, however, intended to mean elimination of risk, ${ }^{56}$ and EPA has interpreted SARA to permit choosing from a range of degrees of risk depending on the circumstances. ${ }^{57}$

2. Characteristics of the Unreasonable Risk Standard. - The unreasonable risk standards established by these statutes share four characteristics, each of which has great significance for regulatory information demands: regulation of risk instead of actual harm, a regulatory goal of less than complete safety, facilitation of cost-risk-benefit balancing, and implementation through case-by-case determinations.

The first feature-regulation of risk instead of harm-contrasts with, and is a reaction to, the traditional tort law rule that damages can

52. Id. § 9602(a).

53. Id. $\S \S 9602(a), 9603(a)$ (CERCLA release notification). Similar listing provisions may be found in the Emergency Planning and Community Right-to-Know Act (EPCRA) provision for release notification. Id. § 11,023(d) (revision based on toxicity and exposure or in some cases on toxicity alone).

54. Id. $\$ 9621(\mathrm{~b})(1)$.

55. Id. $\S 9621$ (d)(1). See generally Brown, EPA's Resolution of the Conflict Between Cleanup Costs and the Law in Setting Cleanup Standards Under Superfund, 15 Colum. J. Envtl. L. 241, 248-78 (1990) (providing detailed description of "how clean is clean" controversy under CERCLA).

56. See H.R. Conf. Rep. No. 962, 99th Cong., 2d Sess. 246, reprinted in 1986 U.S. Code Cong. \& Admin. News 3276, 3339.

57. EPA, National Oil and Hazardous Substances Pollution Contingency Plan, 55 Fed. Reg. 8666, 8716-17 (1990) (to be codified at 40 C.F.R. $\$ 300.430$ (e)(2)) [hereinafter National Contingency Plan]. The theme of nonzero risk appears repeatedly in the NCP. It rejects the adoption of maximum contaminant level goals (MCLG) from the Safe Drinking Water Act (SDWA), 42 U.S.C. $\$ 300 \mathrm{~g}-\mathrm{I}(\mathrm{b})(4)$ (1988), when the MCLG is zero (e.g., for carcinogens). National Contingency Plan, supra, at 8752 (to be codified at 40 C.F.R. $\S 300.430(\mathrm{e})(2)(\mathrm{i})(\mathrm{C}))$. The NCP also weighs the relevant factors as follows: "threshold criteria" are protection of health (not absolute) and compliance with other relevant statutory requirements (which themselves include cost-benefit balancing); "balancing criteria" include toxicity, effectiveness and feasibility, and cost; and "modifying criteria" are state and community acceptance. Id. at 8850 (to be codified at 40 C.F.R. $\S 300.430(f)$ ). Cost, too, can be considered in screening potential remedies, id. at 8849 (to be codified at 40 C.F.R. $\$ 300.430$ (e)(7)(iii) ("grossly excessive"), or where cost is the major difference between two otherwise similar options, id. at 87I4-I5. Indeed, close examination of the NCP in operation reveals that "EPA takes cost into consideration at virtually every stage of the remedy selection process," Brown, supra note 55, at 276-78, resulting in "remedies that only partially mitigate" the site's hazards, Brown, What Is Wrong with the 1990 National Contingency Plan?, 20 Envtl. L. Rep. (Envtl. L. Inst.) $10,371,10,373-76(1990)$. 
be recovered only for actual harm or for the definite likelihood of future harm to the individual plaintiff. ${ }^{58}$ Toxic effects are extremely difficult to prove under the preponderance of the evidence standard of civil litigation because of the great uncertainty caused by the passage of time (latency), the relative unlikelihood of causation (rarity of effect), and the possibility of other causes (nonsignature diseases) present in most toxic substances cases. ${ }^{59}$ As a result, tort law fails to internalize these costs and serves as a poor deterrent to toxic risk creation.

An important impetus for governmental regulation was the desire to overcome this obstacle to successful recovery for toxic injury. Reserve Mining Co. v. EPA ${ }^{60}$ was an early demonstration of the powerful effect of replacing the actual harm standard with a risk-regulating standard. Under the rubric of the Clean Water Act, ${ }^{61}$ the court enjoined asbestos discharges even though they created at most a cause for concern about health effects on city residents. ${ }^{62}$ The toxics statutes likewise sought to

58. See W. Keeton, D. Dobbs, R. Keeton \& D. Owen, Prosser \& Keeton on the Law of Torts $\S 30$, at 165-66 (5th ed. 1984) [hereinafter Prosser \& Keeton].

59. Cases denying recovery for future toxic harm include Sterling v. Velsicol Chem. Corp., 855 F.2d 1188, 1205 (6th Cir. 1988) (denying compensation for unquantified risk for susceptibility to cancer estimated at 25-30\%); Ayers v. Township of Jackson, 106 N.J. 557, 597-99, 525 A.2d 287, 308 (1987). The plaintiffs who have recovered in cases involving future harm have done so for the well-defined and predictable effects of asbestos, where the court was faced with preclusion of a later suit for future injuries under procedural rules. See, e.g., Jackson v. Johns-Manville Sales Corp., 781 F.2d 394, 411-12 (5th Cir.), cert. denied, 478 U.S. 1022 (1986); Gideon v. Johns-Manville Sales Corp., 761 F.2d 1129, 1137 (5th Cir. 1985). Plaintiffs also have been able to recover on several theories of present harm based on risk of future illness, such as indirect risk costs (removal of asbestos, medical monitoring), "cancerphobia," and emotional distress. See generally Pierce, Recovery for Increased Risk of Developing a Future lnjury from Exposure to a Toxic Substance, 19 Envtl. L. Rep. (Envtl. L. Inst.) 10,256, 10,261-63 (1989) (discussing elements of actions for future toxic harm).

The courts by and large have not adopted the suggestions of academic commentators that they accept probabilistic causation and apportioned damages, see, e.g., Delgado, Beyond Sindell: Relation of Cause-in-Fact Rules for Indeterminate Plaintiffs, 70 Calif. L. Rev. 881, 899-902 (1982) (urging proportionate recovery); Robinson, Multiple Causation in Tort Law: Reflections on the DES Cases, 68 Va. L. Rev. 713, 758-67 (1982) (urging probabilistic proof and recovery), or a significantly lowered standard of proof, see, e.g., Black \& Lilienfeld, Epidemiologic Proof in Toxic Tort Litigation, 52 Fordham L. Rev. 732, 735-36 (1984) (urging greater acceptance of epidemiologic proof); Farber, Toxic Causation, 71 Minn. L. Rev. 1219, 1221 (1987) (urging "most likely victim" standard).

60. 514 F.2d 492 (8th Cir. 1975) (en banc) (unanimous opinion), modified sub nom. Reserve Mining Co. v. Lord, 529 F.2d 181 (8th Cir. 1976).

61. 33 U.S.C. §§ 1251-1387 (1988).

62. 514 F.2d at 520. The court took account of the uncertainty in the evidence of harm by allowing Reserve Mining a "reasonable time" to eliminate the effluent. Id. at 538.

In an equally important case, Ethyl Corp. v. EPA, 541 F.2d 1 (D.C. Cir.) (en banc), cert. denied, 426 U.S. 941 (1976), the D.C. Circuit ruled that the phrase "endanger the public health or welfare" in the vehicle emission provisions of the Clean Air Act, 42 U.S.C. $\S 7545$ (c)(1)(A) (1988), means "presents a significant risk of harm," which is 
avoid requiring proof of actual harm, ${ }^{63}$ and regulation of risk provided a convenient solution. For example, FlFRA permits EPA to prohibit conduct without a showing of "actual adverse consequences," 64 and CERCLA applies to threatened as well as actual releases. ${ }^{65}$ Risk is an expression of uncertainty; it is easier to prove than actual harm. Regulation based on risk permits regulatory action based on ex ante collective danger rather than ex post individual injury, and also operates preventively to avert injury to the public as a whole.

The power to regulate on the basis of mere risk, however, is extremely open-ended.66 $\ln$ theory it would permit agency action even when "the burdens of regulation yield a gain of trivial or no value." 67 As a result, the courts have repeatedly rejected regulation of de minimis toxic risks. ${ }^{68}$ Congressional adoption of the unreasonable risk

"something less than actual harm." 541 F.2d at 12-13 \& n.17 (upholding EPA's regulations reducing lead in gasoline); see also id. at 16 ("Here [\$7502 of the Clean Air Act] allows for a somewhat attenuated chain of causation.").

63. See S. Rep. No. 284, 98th Cong., 2d Sess. 59 (1984) (explaining “endangerment" in 1984 RCRA amendments); H.R. Rep. No. 1341, supra note 35, at 32 (discussing TSCA); S. Rep. No. 848, 96th Cong., 2d Sess. 40, 43 (1980) (criticizing courts for rejecting statistical evidence of causation). (1988).

64. Ciba-Geigy Corp. v. EPA, 874 F.2d 277, 280 (5th Cir. 1989); 7 U.S.C. § 136(bb)

65. 42 U.S.C. § 9604(a)(1) (1988). "Threatened" has been read expansively. See, e.g., New York v. Shore Realty Corp., 759 F.2d 1032, 1045 (2d Cir. 1985); see also H.R. Rep. No. 1016, 96th Cong., 2d Sess., pt. 1, at 28, reprinted in 1980 U.S. Code Cong. \& Admin. News 6119, 6131 (defining "hazardous substance" in CERCLA to permit regulation before it actually causes death or injury). Similarly, in enacting the Clean Air Act, Congress did not want the public to experience mass lead poisoning before acting to prevent it. Ethyl Corp., 541 F.2d at 13-18 (citing Reserve Mining Co. v. EPA, 514 F.2d 492, 520 (8th Cir. 1975) (en banc) (unanimous decision), modified sub nom. Reserve Mining Co. v. Lord, 529 F.2d 181 (8th Cir. 1976)); accord Lead lndus. Ass'n, Inc. v. EPA, 647 F.2d 1130, 1152 (D.C. Cir.), cert. denied, 449 U.S. 1042 (1980).

66. The Benzene plurality cast the problem in constitutional terms, expressing concern that this open-endedness would amount to an unconstitutional delegation of legislative power to an agency. See Industrial Union Dep't, AFL-CIO v. American Petroleum Inst. (the Benzene case), 448 U.S. 607, 646 (1980) (plurality) (interpreting the Occupational Health and Safety Act); see also id. at 675 (Rehnquist, J., concurring) (finding unconstitutional delegation).

67. Alabama Power Co. v. Costle, 636 F.2d 323, 360-61 (D.C. Cir. 1979) (interpreting Clean Air Act).

68. See Natural Resources Defense Council, Inc. v. EPA (the Vinyl Chloride case), 824 F.2d 1146, 1153 n.1, 1154 (D.C. Cir. 1987) (en banc) (noting that complete banning of vinyl chloride emissions would wipe out some industries, that virtually all other hazardous air pollutants are also nonthreshold, and that Congress showed no intent to impose such a result); accord Benzene, 448 U.S. at 614-15, 639-43; Alabama Power, 636 F.2d at $360-61$.

This approach avoids the problems that FDA has encountered in implementing the so-called Delaney Clause, 21 U.S.C. $\S 348$ (c)(3)(A) (1988), which forbids the addition to food of any carcinogen regardless of potency. As Professor Merrill explains, because science can detect substances in food in increasingly small quantities, and at the same time toxicology can demonstrate carcinogenesis at some level in more and more chemicals, FDA would be forced to ban many useful and basically innocuous compounds. 
standard made the judicial inference explicit: "safe" need not mean completely safe. This is the second characteristic of the unreasonable risk standard. In nonenvironmental contexts, unreasonable risk has uniformly been taken to permit the continued existence of a greaterthan-zero risk. ${ }^{69}$ In the toxics statutes, nonabsolute safety is a consistent theme. ${ }^{70}$ For example, in TSCA, Congress specifically disavowed the objective of a "risk-free society," if only because it would be impossibly expensive to eliminate completely all toxic chemicals. ${ }^{71}$

Third, while actual harm creates a relatively well defined regulatory goal, risk does not. Likewise, the unreasonable level of risk floats somewhere between harm that is not certain and risk that is not de minimis. Acceptance of nonabsolute or relative safety therefore begs the question, how safe? This is where cost enters the risk formula. The unreasonable risk standard expressly incorporates cost-risk-benefit balancing to answer the question raised by relative safety. ${ }^{72}$ EPA may not

Merrill, supra note 10 , at 9-41. Merrill details the contortions that FDA has gone through to implement the Delaney Clause without causing severe economic dislocation and concludes that the policy cannot be rationalized until it takes into account the degree of risk in some nonabsolute way. Id. at 9-41, 74-75; see also Merrill, supra note 3, at 473-78. Recently, FDA sought to adopt the de minimis risk standard that the courts had approved in non-Delaney contexts. See FDA, Listing of D \& C Orange No. 17 for Use in Externally Applied Drugs and Cosmetics, 51 Fed. Reg. 28,331 (1986) (to be codified at 21 C.F.R. pts. 74, 81, 82); FDA, Listing of D \& C Red No. 19 for Use in Externally Applied Drugs and Cosmetics, 51 Fed. Reg. 28,346 (1986) (to be codified at 21 C.F.R. pts. 74, 81, 82). But the D.C. Circuit rebuffed this attempt to soften the Delaney Clause, finding that Congress in fact had intended it to be "extraordinarily rigid." Public Citizen v. Young, 831 F.2d 1108, 1111-22 (D.C. Cir. 1987), cert. denied, 485 U.S. 1006 (1988).

69. See, e.g., Center for Auto Safety v. Peck, 751 F.2d 1336, 1345 (D.C. Cir. 1985) (National Traffic and Motor Vehicle Safety Act, 15 U.S.C. \$§ 1409-1410 (1988), "does not require NHTSA to establish safety standards with an eye toward any conceivable safety hazard, no matter how insignificant"); Aqua Slide 'N' Dive Corp. v. Consumer Prod. Safety Comm'n, 569 F.2d 831, 840 (5th Cir. 1978) (interpreting "unreasonable risk" to include risks where standard set by Commission "actually promised to reduce the risk without unduly hampering the availability of slides or decreasing their utility"); D.D. Bean \& Sons Co. v. Consumer Prod. Safety Comm'n, 574 F.2d 643, 651 (1st Cir. 1978) (interpreting "unreasonable risk" under Consumer Product Safety Act to mean "a real, and not a speculative, risk"); cf. G. Calabresi, The Costs of Accidents 17-18 (1970) (asserting that absolute safety is a myth of tort analysis); Restatement (Second) of Torts $\$ 402 \mathrm{~A}$ comment i (1965) (recognizing that many products "cannot possibly be made entirely safe for all consumption").

70. See S. Rep. No. 848, supra note 63, at 33 (under CERCLA, "some risks cannot be eliminated"); Committee on Agriculture and Forestry, 92d Cong., 2d Sess., Supplemental Report to Accompany H.R. 10,729, at 8 (Comm. Print 1972), reprinted in 1972 U.S. Code Cong. \& Admin. News 4023, 4030 (recommending that term "unreasonable risk" be used in FIFRA to clarify that complete safety is not required).

71. H.R. Rep. No. 1341, supra note 35, at 13-15; see also Environmental Defense Fund, Inc. v. EPA, 636 F.2d 1267, 1278 n.30 (D.C. Cir. 1980) (rejecting "attempts to equate risk of exposure .... and unreasonable risk").

72. See H.R. Rep. No. 1341, supra note 35, at 14, 35 (describing unreasonable risk in TSCA); S. Rep. No. 698, 94th Cong., 2d Sess. 12, reprinted in 1976 U.S. Code Cong. 
take action without considering the degree of risk involved, the costs associated with regulation, and the benefits that may be achieved by the proposed regulation. ${ }^{73}$

The difficulty of determining an appropriate nonabsolute level of safety in the absence of cost considerations is illustrated by the analysis adopted in Industrial Union Department, AFL-CIO v. American Petroleum Institute (the Benzene case) ${ }^{74}$ and Natural Resources Defense Council, Inc. $v$. $E P A$ (the Vinyl Chloride case)..$^{75}$ These cases require the agency initially to determine the acceptable level of risk solely on the basis of health concerns, before considering nonhealth factors such as cost or technology. ${ }^{76}$ The first step is an extraordinarily artificial process. The choice in the abstract between acceptable risks of one in ten thousand or one in one million cannot help but be highly arbitrary. ${ }^{77}$ Indeed, it is diffcult to imagine how one would go about rationally making such a choice without relying on nonhealth factors like cost and technology. For instance, the courts gave no coherent reason why, based on health

\& Admin. News 4491, 4502 (same); S. Rep. No. 970, 92d Cong., 2d Sess. 10-11, reprinted in 1972 U.S. Code Cong. \& Admin. News 4092, 4095 (describing unreasonable risk in FIFRA).

Unreasonable risk has been understood to mean cost-risk-benefit balancing in other contexts as well. See, e.g., Aqua Slide 'N' Dive Corp., 569 F.2d at 842 (holding that "unreasonable risk" in Consumer Product Safety Act requires agency to consider relationship between safety benefit and cost); see also P. Asch, supra note 2, at 141-42 (describing economists' view that unreasonable risk is risk that is "worth correcting"); Ehrenreich, Pluralist Myths and Powerless Men: The Ideology of Reasonableness in Sexual Harassment Law, 99 Yale L.J. 1177, 1183 (1990) ("reasonableness becomes a vehicle for importing a cost/benefit analysis into [negligence] law").

73. This need not imply any particular formula for weighing each factor. Professor Rodgers has identified four models of cost-benefit balancing: cost-oblivious, which ignores cost altogether; cost-effective, which considers cost in the choice of remedies but not in the choice of whether to regulate; cost-sensitive, which makes cost generally (but vaguely) relevant; and cost-justified, which requires that the benefits of all regulatory actions outweigh their costs. See Rodgers, Benefits, Costs, and Risks: Oversight of Health and Environmental Decisionmaking, 4 Harv. Envtl. L. Rev. 191, 201-14 (1980).

74. 448 U.S. 607 (1980) (plurality).

75. 824 F.2d 1146 (D.C. Cir. 1987) (en banc).

76. Benzene, 448 U.S. at 642-46, 652-58; Vinyl Chloride, 824 F.2d at 1165-66. See also EPA, National Emission Standards for Hazardous Air Pollutants; Benzene Emissions from Maleic Anhydride Plants, Etholbenzene/Styrene Plants, Benzene Storage Vessels, Benzene Equipment Leaks, and Coke By-Product Recovery Plants, 54 Fed. Reg. $38,044,38,044-45$ (1989) (to be codified at 40 C.F.R. pt. 61) [hereinafter Benzene NESHAP] (adopting I in 10,000 standard for initial determination of unacceptable risk, and 1 in $1,000,000$ for margin of safety taking cost and feasibility into account).

77. In the Benzene NESHAP, for example, EPA provided no real explanation for its choice, even though it discussed the issue at great length. Instead, it expressed a clear preference for a flexible level. Benzene NESHAP, supra note 76, at 38,058; see also Note, "Acceptable" Risk for Hazardous Air Pollutants, 13 Harv. Envtl. L. Rev. 535, 552-57 (1989) (discussing methods for determining acceptable risk). NRDC's reasons for preferring the 1 in 1,000,000 standard were based on general arguments about individuals' rights to clean air. Id. at 543. But cf. Schroeder, Rights Against Risks, 86 Colum. L. Rev. 495, 510-11 (1986) (criticizing rights as a basis for risk decisions). 
concerns only, we should accept any nonzero risk from toxic substances. ${ }^{78}$ They failed to articulate any such reasons because there are none: we accept risk precisely on account of nonhealth factors. We accept some risk because zero risk is inconvenient, infeasible, or unaffordable. Not surprisingly, EPA found little to like in the Vinyl Chloride analysis. In its response to the court, EPA made very little effort to hide its irritation. It noted the "uniqueness" (among EPA statutes) of the two-step analysis and expressed a clear preference for the "integrated approaches" under the unreasonable risk standards of FIFRA, TSCA, RCRA, and CERCLA. ${ }^{79}$

Finally, because the unreasonable risk standard is based on the balancing of several disparate factors, it entails ad hoc, case-by-case decision making. Congress seems to approve of the case-by-case approach, ${ }^{80}$ EPA certainly prefers it, ${ }^{81}$ and the Benzene Court's rejection of OSHA's Generic Cancer Policy provides ample warning of similar judicial preferences. ${ }^{82}$ Industry also prefers the case-by-case approach,

78. Both Benzene, 448 U.S. at 642, and Vinyl Chloride, 824 F.2d at 1165, make much of the existence of risk in ordinary daily activities like driving, but the existence of these risks hardly explains why we should accept any additional (albeit lesser) ones. If anything, this argument cuts the other way.

79. Benzene NESHAP, supra note 76, at 38,049. The two-step approach taken by Congress in the Safe Drinking Water Act (SDWA), 42 U.S.C. $\S \S 300 \mathrm{f}-300 \mathrm{j}-26$ (1988), cited by EPA, Benzene-NESHAP, supra note 76, at 38,049, provides an illuminating contrast. That statute requires the establishment of purely health-based maximum contaminant level goals (MCGLs). See 42 U.S.C. $\$ 300 \mathrm{~g}-1$ (b)(1). However, EPA actually enforces only the maximum contaminant levels (MCLs) which are set "as close to the maximum contaminant goal as is feasible" (including cost and technology considerations). $1 \mathrm{~d}$. $\$ 300 \mathrm{~g}-1(\mathrm{~b})(4)$-(5). Under this structure, EPA is free to place tbe MCGL for carcinogens at zero on the ground that there is no threshold level of safety based on health concerns alone. The nonzero enforcement level (the MCL) is set by reference to cost and technology. See EPA, National Primary and Secondary Drinking Water Regulations; Synthetic Organic Chemicals and Inorganic Chemicals, 55 Fed. Reg. 30,370, 30,373-75 (I990) (to be codified at 40 C.F.R. pts. 14I-143) (proposed July 25, 1990); see also National Contingency Plan, supra note 57, at 8751-52 (explaining SDWA process).

80. See H.R. Rep. No. I34I, supra note 35, at 13-I4 (TSCA); H.R. Conf. Rep. No. I679, supra note 38, at 60-61, reprinted in I976 U.S. Code Cong. \& Admin. News at 4544-46 (TSCA); see also Ausimont U.S.A. Inc. v. EPA, 838 F.2d 93, 98 (3d Cir. 1988) (interpreting TSCA).

81. See, e.g., Benzene NESHAP, supra note 76, at 38,045, 38,049; EPA, Reportable Quantity Adjustments, 52 Fed. Reg. 8I40, 8144 (1987) (to be codified at 40 C.F.R. pts. 117,302 ) (proposed Mar. 16, 1987) (establishing proposed methodology for ranking carcinogens under CERCLA); EPA, Cbloromethane and Chlorinated Benzenes Proposed Test Rule; Amendment to Proposed Health Effects Standards, 45 Fed. Reg. 48,524, 48,528-29 (1980) (to be codified at 40 C.F.R. pt. 773) (proposed July 18, 1990) [hereinafter Chloromethane Test Rule] (setting out interpretation of "may present an unreasonable risk" standard that EPA continues to follow).

82. Industrial Union Dep't, AFL-CIO v: American Petroleum Inst. (the Benzene case), 448 U.S. 607, 662 (1980) (plurality); see infra notes 115-117 and accompanying text. The Court believed that OSHA improperly shifted the burden of proof from the agency to industry. 448 U.S. at 659 . Courts are, of course, generally comfortable with 
presumably because it permits greater consideration of cost and technology and allows for higher levels of acceptable risk. ${ }^{83}$

There can be no question that the case-by-case approach gives the agency more flexibility and permits it to consider a wider range of relevant factors. But flexibility has a price. In addition to reviewing individually the thousands of chemicals already in existence, regulatory agencies must evaluate each new chemical as it is added to the market. $^{84}$ Moreover, because the agency must separately consider and justify each case, every one is potentially the subject of protracted litigation. EPA's discretion in ad hoc balancing can be reined in to some extent by setting upper bounds on risks levels ${ }^{85}$ or by establishing fixed weighting formulas. ${ }^{86}$ Nevertheless, case-by-case balancingtogether with risk regulation, nonabsolute safety, and nonhealth considerations-will remain an integral part of the unreasonable risk standard.

\section{B. Implementation of the Unreasonable Risk Standard: Quantitative Risk Assessment}

In order to justify its decisions taken under the unreasonable risk standard, EPA and other agencies concerned with toxic substances have developed quantitative risk assessment to determine whether the risk posed by a substance is "unreasonable," and thus to determine whether, what kind, and how much regulatory action is necessary. Quantitative risk assessment is a powerful tool for analyzing risk because it assures consideration of all of the technical factors that are relevant to risk decisions. But its application also demands an amount of data that widens the information gap for toxic substances.

1. Theory: Unreasonable Risk and Quantitative Risk Assessment. Quantitative risk assessment is EPA's analytical method of choice for measuring the probable health effects of toxic substances. Its overall purpose is to "organize and express what can be stated about risks that are not subject to direct observation and measurement" based on an

case-by-case balancing, for example, in the risk-utility test for design defects in products. See Forester v. Consumer Prod. Safety Comm'n, 559 F.2d 774, 789 (D.C. Cir. 1977) ("unreasonable risk" involves "a balancing test like that familiar in tort law"); Prosser \& Keeton, supra note $58, \S 99$.

83. See, e.g., Note, supra note 77 , at $543-48$ (describing supporters of the various possible responses to the Vinyl Chloride decision).

84. See Babich, Understanding the New Era in Environmental Law, 41 S.C.L. Rev. 733, 739 (1990).

85. See Benzene NESHAP, supra note 76 , at 38,046 ; Note, supra note 77 , at 556 .

86. See, e.g., National Contingency Plan, supra note 57, at 8723-31 (to be codified at 40 C.F.R. $\$ 300.430(\mathrm{f})$ ) (establishing hierarchy of criteria for selection of CERCLA remedy); H.R. Rep. No. 198, supra note 42 , pt. 1, at 37, reprinted in 1984 U.S. Code Cong. \& Admin. News at 5596 (under RCRA cost is to be considered only in cases of severe economic hardship). 
analysis of all available toxicity and exposure data. ${ }^{87}$ In theory, this approach provides an objective evaluation of the risk posed by a chemical. ${ }^{88}$

The basic risk assessment calculation is simple and parallels the elements of risk noted above: ${ }^{89}$ the toxicity (potency) of the chemical is multiplied by the human exposure to it. 90 In the usual formulation, the first part of the quantitative risk assessment process has four steps. First, hazard identification determines whether a substance is toxic. Standing alone, hazard identification might be called qualitative risk assessment. It merely identifies substances that are toxic without measuring in detail their potency or likely effects. Studies that indicate probable causation of health effects, for example, fit into this stage. The second step, dose-response modeling, predicts from toxicity testing data the toxic effect of a given amount of exposure to a given agent. This phase makes use of sophisticated controlled experiments, notably chronic toxicity tests and large-scale animal bioassays, to achieve estimates. To predict dose-response at low levels over long periods, however, the risk assessor must rely almost exclusively on theoretical models. These models are complex, difficult to develop, and anything but definitive.

Dose-response modeling mediates between hazard identification and the third step-exposure assessment-which undertakes to estimate the amount of a chemical with which people come into contact. It can be difficult to monitor exposure and to determine pathways. In addition, extrapolating from exposure to actual dose requires the modeling of human and animal metabolism. Different routes of exposure (ingestion, inhalation, or absorption) yield different levels of intoxication. Finally, the fourth step, risk characterization, is the process of

87. Rodricks, Brett \& Wrenn, Significant Risk Decisions in Federal Regulatory Agencies, 7 Regnlatory Toxicology \& Pharmacology 307, 307 (1987). According to the National Contingency Plan, "the purpose of risk assessment in the Superfund program is to provide a framework for developing risk information necessary to assist decisionmaking at remedial sites. Risk assessment provides a consistent process for evaluating and documenting threats to human health and the environment posed by hazardous material at sites." See National Contingency Plan, supra note 57, at 8709.

88. See infra note 92.

89. See supra notes 58-86 and accompanying text.

90. The description of quantitative risk assessment in this Article is drawn from the voluminous legal literature. See EPA, Risk Assessment and Management: Framework for Decision Making (1984) [hereinafter EPA, Framework]; EPA, Guidelines for Carcinogen Risk Assessment, 51 Fed. Reg. 33,992 (1986) [hereinafter EPA, Carcinogen Risk Assessment]; National Research Council, Risk Assessment in the Federal Government: Managing the Process (1983) [hereinafter Managing the Process]; Office of Science \& Technology Policy, Chemical Carcinogens; A Review of the Science and Its Associated Principles, 50 Fed. Reg. I0,372 (1985). Useful descriptive commentaries include: W. Rowe, An Anatomy of Risk (1988); Lave, Methods of Risk Assessment, in Quantitative Risk Assessment in Regnlation 23, 23 (L. Lave ed. 1982); Leape, supra note 10; Whipple, Fundamentals of Risk Assessment, 16 Envtl. L. Rep. (Envtl. L. Inst.) 10,190 (1986). 
combining hazard and exposure data, and of identifying the assumptions that underlie them and the uncertainties within them. The result is a quantitative evaluation-a number or range of numbers-that represents the excess deaths or illnesses expected from exposure to a toxic substance. ${ }^{91}$

These four steps comprise risk assessment, the first, and predominantly scientific, part of a broader decision-making process. The second part of the process, risk management, involves consideration of political and policy questions such as acceptable levels of risk and regulatory responses, and of nonhealth factors like economic and technological feasibility. ${ }^{92}$ it deals with the "unreasonable," as it were, in unreasonable risk. As a rigid dichotomy, of course, this is an unrealistic view of government action and of science, since political and judgmental factors pervade the entire assessment function. ${ }^{93}$ Taken as a whole, however, the risk assessment and management process forms a bridge between science and policy, while attempting to maintain their separate identities. ${ }^{94}$ Further, as a reflection of the practice of gathering information before making decisions, it seems unexceptionable.

Quantitative risk assessment fits hand in glove with each of the previously identified characteristics of unreasonable risk. ${ }^{95}$ First, quantitative risk assessment measures risk rather than harm. It measures group effects rather than effects on individuals, and it is concerned with prospective hazards rather than retrospective causation. ${ }^{96}$ Second, implicit in using quantitative risk assessment is the recoguition that the existence of risk at some level is not in itself a sufficient reason to prohibit

91. The quantitative conclusion can be expressed as individual risk (e.g., 1 in 10,000 chance of getting cancer from this source), rate of excess deaths (e.g., 1 per $10,000)$, or absolute number of excess deaths in the exposed population. The differences between these terms are discussed in the Benzene NESHAP, supra note 76, at 38,045-46.

92. Former EPA Administrator Ruckelshaus was a leading advocate of bifurcation between risk assessment and risk management. See Ruckelshaus, Risk in a Free Society, 14 Envtl. L. Rep. (Envtl. L. Inst.) 10,190 (1984); Ruckelshaus, Science, Risk, and Public Policy, 221 Science 1026, 1027-28 (1983).

93. See, e.g., Latin, Good Science, supra note 4, at 93-94; Leape, supra note 10, at 113. At best, EPA must operate in a world of uncertainty, incomplete data, and genuine differences between scientists in interpretation of and inferences from the available data. The risk assessor must make all kinds of assumptions, and the choice between conservative, risk-preferring, or middle-ground ones is clearly a policy question. See McGarity, supra note 28, at 183-87; cf. Doniger, The Gospel of Risk Management: Should We Be Converted?, 14 Envtl. L. Rep. (Envtl. L. Inst.) 10,222, 10,223 (1984) (EPA's techniques for estimating size of cancer risks "cannot be supported either as a rational application of the statutory criteria or as a sensible public health policy judgment.").

The use of a numerical risk assessment is itself a policy choice that may slight important social and political considerations. See Gillette \& Krier, supra note 5 , at $1070-85$.

94. See EPA, Framework, supra note 90, at 1-2.

95. See supra notes $58-86$ and accompanying text.

96. See Schroeder, supra note 77, at 500-01. 
exposure to a toxic chemical. There is little point to the whole enterprise of precise measurement of risk unless the agency is prepared to accept a nonzero degree of risk. ${ }^{97}$ Otherwise, qualitative risk assessment would suffice. Third, quantitative risk assessment provides the framework for the cost-risk-benefit analyses that the toxics statutes employ because it places a numerical value on risk that can be compared with other values at the risk management stage. ${ }^{98}$ This characteristic can be seen as the method's primary virtue, ${ }^{99}$ or its primary evil. ${ }^{100}$ Quantitative risk assessment also conveniently separates the determination that a risk exists from the risk management determination of what to do about it. This distinction provides the opportunity and justification for considering nonhealth factors in the management phase. Finally, quantitative risk assessment is by its nature a case-by-case approach. Its conclusions are based on toxicity and exposure information about particular chemicals, and it strives to achieve a level of precision about risk greater than that which can be achieved by generalized estimates. It is an alternative to generic or qualitative approaches to risk regulation.

2. Practice: Regulatory and Judicial Demands for Quantitative Risk Assessment. - Curiously, the original interest in quantitative risk assessment did not come from Congress. Neither the language of the toxics statutes nor the legislative deliberations behind them suggest the need for the technique. Some legislators specifically disclaimed reliance on a quantitative scientific foundation to support regulatory action. ${ }^{101}$ As of

97. For example, FDA's abortive de minimis policy for the Delaney Clause, 21 U.S.C. $\$ 348$ (c)(3)(A) (1988), was a creature of quantitative risk assessment, which provided the basis for FDA's claim of an extant but minimal risk. See Merrill, supra note 10, at 76-78. FDA's efforts to utilize the de minimis policy were founded on detailed quantitative risk assessments. See FDA, Listing of D \& C Red No. 19 for Use in Externally Applied Drugs and Cosmetics, supra note 68, at 28,349-60 (finding that D \& C Red No. 19 was carcinogen in laboratory animals, triggering Delaney Clause, but that 1 in $9,000,000$ risk was insignificant). Conversely, risk assessment at FDA appears to have originated with the 1962 exception to the Delaney Clause that permitted a nonzero risk of cancer for drugs used in food animals. Rodricks, Origins of Risk Assessment in Food Safety Decision Making, 7 J. Am. C. Toxicology 539, 539-41 (1988).

98. See Leape, supra note 10 , at $87-88$.

99. See, e.g., EPA, Framework, supra note 90 , at 27-33; Whipple, supra note 90 , at 10,191-92.

100. See, e.g., Green, The Role of Congress in Risk Management, 16 Envtl. L. Rep. (Envtl. L. Inst.) 10,220, 10,223-24 (1986) (David Doniger, NRDC attorney, observing that "the major use of risk assessment [is] cost-benefit analysis," of which Doniger is skeptical); Leape, supra note 10 , at $87-88$.

101. See S. Rep. No. 284, supra note 63, at 59 (RCRA); S. Rep. No. 698, supra note 72, at I3, reprinted in 1976 U.S. Code Cong. \& Admin. News at 4530 (TSCA); see also 132 Cong. Rec. S15,064-66 (daily ed. Oct. 3, 1986) (Joint Explanatory Statement of TSCA asbestos amendments and remarks of Sen. Stafford).

The 1990 Clean Air Act amendments, however, send mixed signals concerning Congress's commitment to the unreasonable risk standard and its acceptance of quantitative risk assessment as the standard-setting methodology. For toxic air pollutants, Congress inverted the health-then-feasibility approach that was taken in the original 
1980 , by which time the major toxics statutes were in place, the main federal agencies responsible for regulating toxic substances displayed a similar diffidence toward quantitative risk assessment. They had considerable misgivings about the ability of science to arrive at plausible calculations of risk, so they relied primarily on qualitative risk assessment to identify carcinogens. Quantitative risk assessment was applied only to issues like setting priorities for regulatory action or choosing the degree of regulation, but not to the central unreasonable risk decision. ${ }^{102}$

In the 1980s, quantitative risk assessment became popular for use in the unreasonable risk decision as the result of three contemporaneous, though not directly related, developments. First, efforts to rationalize the federal government's disparate approaches to toxic risk in the late 1970s renewed interest in the methodology of quantitative risk assessment. ${ }^{103}$ The impetus generated by a National Academy of Sciences report recommending the use of the method for assessing toxic hazards, ${ }^{104}$ as well as increased scientific ability to obtain appropriate background data, made the process considerably more attractive to

Clean Air Act, 42 U.S.C. $\$ 7412(\mathrm{~b})(1)(B)$ (1982) and explicated in the Vinyl Chloride case. Natural Resources Defense Council, Inc. v. EPA, 824 F.2d 1146, 1165-66 (D.C. Cir. 1987) (en banc). Under the amended Act, EPA first sets toxic emissions standards on technology-based criteria-the "maximum achievable control technology"-and only some years later is required to impose health-based emissions limitations for the residual risk. Clean Air Act Amendments of 1990, Pub. L. No. 101-549, § 301(d)(2), (f)(2)(A), 104 Stat. 2399, 2531 (1990) (to be codified at 42 U.S.C. $\$ \$ 7412(d)(2),(f)(2)(A)$ ). Thus, on one hand, Congress demonstrated that it was anxious to get on with toxics regulation that had lagged under the Clean Air Act, and to accomplish this goal it adopted a less information intensive standard than unreasonable risk. See supra note 28 . On the other hand, Congress, which had not previously taken a clear stand on quantitative risk assessment, expressly adopted a numerical risk standard $(1$ in $1,000,000)$ for the permissible post-regulation level of risk. Pub. L. No. 101-549, § 301(f)(2)(A), 104 Stat. at 2531 (to be codified at 42 U.S.C. $\$ 7412(f)(2)(A))$. This, it would seem, accepts the strongestand highly controversial-claims for the precision of quantitative risk assessment. That is, Congress was apparently willing not only to allow it to be used to set an undefined term like "unreasonable," but also to rely on its ability to predict compliance with precise numerical standards.

102. See, e.g., EPA, National Emission Standards for Hazardous Air Pollutants; Policy and Procedures for Identifying, Assessing, and Regulating Airborne Substances Posing a Risk of Cancer, 44 Fed. Reg. 58,642, 58,646-49 (1979); Scientific Bases, supra note 10, at 39,871-72; OSHA, Identification, Classification and Regulation of Potential Occupational Carcinogens, 45 Fed. Reg. 5002, 5240-41, 5256 (1980) [hereinafter OSHA, Occupational Carcinogens] ("Final Cancer Policy"); see also Latin, Good Science, supra note 4, at 95-98 (tracing quantitative risk assessment at EPA); Leape, supra note 10, at 108-12 (recommending use of quantitative risk assessment for rough priority classifications but not for setting standards).

103. See Merrill, supra note 3, at 464-66 (citing various efforts to coordinate carcinogen policy during the Carter Administration).

104. Managing the Process, supra note 90, at 151-71. 
agency scientists. ${ }^{105}$ Second, agency policy makers in the Reagan Administration, its environmental credibility in tatters during and after the Burford-Watt era, saw in the requirement of quantification an ostensibly neutral process for justifying its actions. ${ }^{106}$ Or its inaction: quantitative risk assessment could be used to demand that federal agencies justify regulatory action in cost-benefit terms ${ }^{107}$, and also-because it is so resource intensive-to limit the amount of regulatory action generally. 108

Third, during the $1980 \mathrm{~s}$, the federal courts moved from a deferential approach to agency regulation of toxic substances to a highly critical one. ${ }^{109}$ The new judicial approach placed a premium on the ability of regulatory agencies to provide at least an apparent objectivity in their judgments, which in turn put pressure on the agencies to quantify the bases for their decisions. The approach of the early 1970s, epitomized by the opinion in Industrial Union Department, AFL-CIO $v$. Hodgson, ${ }^{110}$ recognized that agency decisions in uncertain conditions at the "frontiers of science" could not be reviewed like usual adjudication. ${ }^{111}$ At the same time, however, the courts were developing the

105. Goldstein, Risk Assessment and the Interface Between Science and Law, 14 Colum. J. Envtl. L. 343, 343 (1989); Whipple, supra note 90, at 10,192.

106. See Goldstein, supra note 105 , at 343 (characterizing adoption of quantitative risk assessment as effort to restore confidence in EPA); Whipple, supra note 90, at 10,190 (tracing rise of quantitative risk assessment to "politicized regulatory environment").

107. Insistence on cost-benefit assessment was a central tenet of Reaganism. See, e.g., Exec. Order No. 12,291, 3 C.F.R. 127 (1982), reprinted in 5 U.S.C. $\$ 601$ app. at $473-76$ (1988) (requiring all agencies to undertake cost-benefit analyses of proposed regulatory actions).

108. See Latin, Good Science, supra note 4, at 94-95; Morgan, Bad Science and Good Policy Analysis, 201 Science 971, 971 (1978). Compare Singer, Environmental Strategies with Uncertain Science, Regulation, Winter 1990, at 65, 68-69 (conservative writer advocating delay in action on global warming to develop more information) with National Coalition Against the Misuse of Pesticides v. EPA, 867 F.2d 636, 639 (D.C. Cir. 1989) (environmental group arguing that available information was sufficient to regulate pesticide and that additional information gathering should not be permitted to slow agency action) and Natural Resources Defense Council, Inc. v. Thomas, 689 F. Supp. 246, 260 (S.D.N.Y. 1988) (criticizing, but finding no jurisdiction to remedy, EPA's "endless reviews, open-ended studies, [and] proclaimed needs for further analyses"), aff'd, 885 F.2d 1067 (2d Cir. 1989).

109. The relationship between judicial action and agency response is not as direct or simple as one might expect. Nevertheless, regulators can hardly be oblivious to the demands placed upon them by the courts. See Mashaw \& Harfst, Inside the National Highway Traffic Safety Administration: Legal Determinants of Bureaucratic Organization and Performance, 57 U. Chi. L. Rev. 443, 443 (1990) (agency behavior is determined both by "external legal control" of courts and by "internal factors such as office organization, established routines, resource allocations, professional cadres, and unique leaders").

110. 499 F.2d 467 (D.C. Cir. 1974).

111. Id. at 474-75; accord Ethyl Corp. v. EPA, 541 F.2d 1, 23 (D.C. Cir. 1976) (en banc) (analogizing toxics decisions to agency predictions, to which courts have traditionally deferred), cert. denied, 426 U.S. 941 (1976); Lead Indus. Ass'n, Inc. v. EPA, 647 
"hard look" doctrine, which emphasized rigorous examination of agency rationales. ${ }^{112}$ One of the fruits of hard look review was aggressive analysis of agency evidence in toxic substances cases. The most extreme example is Gulf South Insulation v. Consumer Product Safety Commission, 113 in which the Fifth Circuit overturned OSHA's action based on the court's substantive review, concluding that the agency's evidence was "not good science." 114

The Benzene case was a turning point. OSHA had rejected quantitative risk assessment in favor of a Generic Cancer Policy, but the Supreme Court rejected the generic policy and required OSHA to make a threshold finding in each case that the risk posed by preregulation conditions was "significant." 115 Despite the Court's protestations to the contrary, 116 OSHA drew the natural inference from the plurality opinion that the agency must quantify the risk before it can determine its significance. ${ }^{117}$

F.2d 1130, 1146-47 (D.C. Cir.) (Clean Air Act case following Hodgson and Ethyl), cert. denied, 449 U.S. 1042 (1980); United Steelworkers v. Marshall, 647 F.2d 1189, 1248 (D.C. Cir. 1980) (OSHA case, distinguishing Benzene), cert. denied, 453 U.S. 913 (1981).

112. More precisely, the courts sought to ensure that the agency took a hard look at all of the relevant issues. The theory of hard look review is set out and debated in the celebrated opinions of Judges Wright, Leventhal, and Bazelon in Ethyl Corp., 541 F.2d at $1,66,68$.

113. 701 F.2d 1137 (5th Cir. 1983).

114. Id. at 1140, 1146; see also Asbestos Information Ass'n/N. Am. v. OSHA, 727 F.2d 415, 425-26 (5th Cir. 1984) (rejecting evidence based on uncertain assessment analysis); Texas Indep. Ginners Ass'n v. Marshall, 630 F.2d 398, 406-07 (5th Cir. 1980) (agency bears burden of demonstrating existence of risk).

Professors Abraham and Merrill divide judicial approaches to agency decisions into deference, avoidance (i.e., overturning agency action but on ostensibly nonfactual grounds), and confrontation (i.e., direct factual review on the merits). They view Gulf South as a rare example of the last category, and they are critical of the decision. See Abraham \& Merrill, supra note 11, at 97-99. Courts in recent toxic torts decisions have shown an inclination toward the Gulf South approach. See, e.g., Ealy v. RichardsonMerrell, Inc., 897 F.2d 1159, 1162 (D.C. Cir.), cert. denied, 111 S. Ct. 370 (1990); Brock v. Merrell Dow Pharmaceuticals, Inc., 874 F.2d 307, 309-10 (5th Cir.), modified per curiam, 884 F.2d 166 (5th Cir. 1989), cert. denied, 110 S. Ct. 1511 (1990). But see Ferebee v. Chevron Chem. Co., 736 F.2d I529, 1536 (D.C. Cir.) (stating that court should not substitute its own evaluation of plaintiff's risk assessment for the jury's), cert. denied, 469 U.S. 1062 (1984).

115. Industrial Union Dep't, AFL-CIO v. American Petroleum Inst. (the Benzene case), 448 U.S. 607, 642 (1980) (plurality). The Court adopted an avoidance approach, concluding that the Generic Cancer Policy improperly shifted the burden of proof to industry. See Abraham \& Merrill, supra note 11, at 98.

116. See 448 U.S. at 652-53.

117. See OSHA, Occupational Exposure to Benzene, 52 Fed. Reg. 34,460, 34,461 (1987) (to be codified at 29 C.F.R. pt. 1910) (concluding that Benzene requires OSHA to "attempt to quantify risk, if possible, and determine whether the risk is significant"). See generally Latin, Toxic Health Risks, supra note 4, at 383 (criticizing requirement of quantification). OSHA's core evidentiary support for the subsequent cotton dust rule was quantitative, as the Supreme Court specifically noted on review. American Textile Mfrs. Inst. v. Donovan, 452 U.S. 490, 505 n.25 (1981) (upholding OSHA standard). 
EPA has followed suit and now relies heavily on quantitative risk assessment to support its toxics regulations. ${ }^{118}$ For example, the preamble to the most recent version of the CERCLA National Contingency Plan indicates that EPA is adopting risk assessment "to help provide justification for performing remedial action."119 The agency's choice of words strongly suggests that policy makers find the apparent precision of quantitative risk assessment extremely useful in supporting significant regulatory choices that are subjected to intense public and judicial scrutiny. Even if the precision is illusory, quantitative risk assessment provides an ostensibly objective justification for the imposition of large costs on the economy.

Finally, the centrality of quantitative risk assessment to EPA decision making is virtually assured by Administrator William Reilly's strong interest in developing a comprehensive, integrated environmental policy that allocates governmental resources to the most serious problems and to those problems in which governmental resources will achieve the greatest improvement. ${ }^{120}$ The obvious obstacle for this plan is the difficulty of comparing across risks: a grand strategy must evaluate not only human health risks from many sources, but also ecological risks. ${ }^{121}$ Quantification of risks, from this perspective, is the "common metric" upon which such comparisons can be based. 122

\section{The Data Gap}

Each stage of the regulatory process ${ }^{123}$ produces a deficit between the amount of information needed for regulatory decision making and the amount that is available. This data gap is wide and expanding. The choice of response phase requires by far the greatest quantity of infor-

\section{See supra text accompanying notes $87-90$.}

119. National Contingency Plan, supra note 57 , at $8709,8847-50$ (to be codified at 40 C.F.R. $\S \S 300.430$ (d), (e)(2)). Risk assessment is used throughout the CERCLA process, from establishing a baseline for clean up at the site to determining the appropriate range of acceptable risk to choosing a response. ld.

The Vinyl Chloride analysis, which closely follows Benzene, displays a similar preference for quantification, see Natural Resources Defense Council, Inc. v. EPA, 824 F.2d $1146,1164-65$ (D.C. Cir. 1987) (en banc), and EPA's response to Vinyl Chloride was also quantification, see Benzene NESHAP, supra note 76 , at 38,045 .

120. Reilly, Aiming Before We Shoot: The Quiet Revolution in Environmental Policy, Speech to the National Press Club 3-5 (Sept. 26, 1990) (on file with Columbia Law Review); see also Science Advisory Board, EPA, Reducing Risk: Setting Priorities and Strategies for Environmental Protection 16, 19-20 (1990) [hereinafter Reducing Risk] (concluding that EPA should establish risk-based priorities in its strategic planning). Reilly's paean to "sound science," Reilly, supra, at 4, may be the dark cloud to this silver lining. One might ask whether too much will be spent on getting organized and too little on taking action.

121. Reducing Risk, supra note 120 , at 17 (criticizing earlier study for exclusive focus on human health).

122. Reilly, supra note 120 , at 4 .

123. See supra note 22 and accompanying text. 
mation, in large part because it involves the unreasonable risk standard and quantitative risk assessment. But the other phases of the regulatory process make substantial demands for data, as well. These requirements would be reduced, but by no means eliminated, by alteration or replacement of the unreasonable risk standard or quantitative risk assessment. Recent right-to-know legislation has added further demands for information. This section examines the nature and extent of those demands.

1. Standard Setting and Quantitative Risk Assessment. - As we have seen, quantitative risk assessment is an information-intensive methodology. 1ronically, it is information intensive precisely because we lack information concerning the health effects of toxic substances and the mechanism of carcinogenesis. As a result, the quantitative risk assessment process is subject to many errors based on faulty or mishandled assumptions. ${ }^{124}$ Given the present state of knowledge, the use of some assumptions is inevitable, but real confidence in quantitative risk assessment can be achieved only with substantial amounts of data.

Each step of the quantitative risk assessment process has its own information requirements. ${ }^{125}$ Hazard identification uses several levels of testing, which involve increasing complexity, duration, accuracy, and cost. At a minimum, the data used to identify a hazard must be good enough to exclude the effects of other chemicals; otherwise, there is no identification. Initial inquiries, such as similarities in chemical structure or activity and acute and chronic toxicity tests, provide a very rough sense of a chemical's potential for carcinogenesis. ${ }^{126}$ The next level is examination of the effects of a substance on individual cells, a test that is useful because some changes in a cell's genetic material are characteristic of changes that occur in tumor cells. ${ }^{127}$ These tests are shortterm and relatively cheap, but they are useful only for screening. ${ }^{128}$ Epidemiology is an enormously powerful tool for identifying carcinogens because it provides direct evidence of human health effects. However, a prospective study of long-latency diseases does not reach fruition for years or decades, and it is impossible to control many im-

124. See Paustenbach, Health Risk Assessments: Opportunities and Pitfalls, 14 Colum. J. Envtl. L. 379, 385-409 (1989) (describing "pitfalls" in quantitative risk assessment methodology from point of view of "the regulated community").

125. The steps of quantitative risk assessment are discussed supra notes 87-91 and accompanying text.

126. See Slesin \& Sandler, Categorization of Chemicals Under the Toxic Substances Control Act, 7 Ecology L.Q. 359, 374-82 (1978).

127. These include the so-called Ames mutagenicity test. See Ames, Identifying Environmental Chemicals Causing Mutations and Cancer, 204 Science 587, 589-92 (1979); Maugh, Chemical Carcinogens: The Scientific Basis for Regulation, 201 Science $1200,1202-04$ (1978).

128. Simple oral acute toxicity tests may cost less than $\$ 1,000$. The next level, however, jumps to several thousand. Subchronic toxicity tests, the next level of testing, cost about $\$ 100,000$. Lyndon, Information Economics, supra note 6, at 1812-13. 
portant variables in retrospective studies, even assuming that the necessary historical data are available. ${ }^{129}$ Moreover, epidemiologic studies detect only relatively large increases in risk, so negative findings must be considered inconclusive. ${ }^{130}$ In essence, hazard identification is a first look at the relevant toxicity data. ${ }^{131}$

The dose-response phase requires more data. Screening tests and epidemiology at best identify suspected carcinogens. They do not exonerate substances, and they can indicate potency only very roughly. The test considered most determinative of both carcinogenicity and potency is the animal bioassay, which is a long-term, high-dose study of the effects of a chemical on animals under strictly controlled conditions. If the test is well designed and executed (which may not always be the case given the complexity of the task) its particular results are reliable, though still subject to false negatives. ${ }^{132}$ Even so, bioassays , are extremely expensive and take years to complete. ${ }^{133}$

Unfortunately, bioassays do not, directly measure low-dose responses in human beings. Therefore, two and often three extrapolations using mathematical models are required. Since most testing is done at a relatively high dose to induce effects, a dose-response curve is used as the basis for calculating the low-dose response. ${ }^{134}$ Several

129. Whipple, supra note 90 , at 10,193 ; see also Black \& Lilienfeld, supra note 59 , at 733-64 (general discussion of epidemiology); Dore, A Commentary on the Use of Epidemiological Evidence in Demonstrating Cause-in-Fact, 7 Harv. Envtl. L. Rev. 429, 435-38 (1983) (advocating limits on use of epidemiological evidence in tort litigation); Hall \& Silbergeld, Reappraising Epidemiology: A Response to Mr. Dore, 7 Harv. Envtl. L. Rev. 441, 441-43, 445-46 (1983) (arguing that epidemiology can show significant relationships between response to chemical and disease).

130. EPA, Carcinogen Risk Assessment, supra note 90, at 33,995-96.

131. Paustenbach, supra note 124 , at $386-89$.

132. For low-incidence cancers, one would need thousands, if not millions, of animals to be statistically certain of avoiding false negatives and positives. See Weinberg, Science and Trans-Science, 10 Minerva 209, 210 (1972). At an average cost of $\$ 1,000$ per animal, the expense would be enormous. Worthen, The Last Shall Be First, and the First Last: Ruminations on the Past, Present and Future Course of Government Regulation of Hazardous Pollutants, 1989 B.Y.U. L. Rev. 1113, 1124 \& n.65.

133. Simply to conduct studies in rodents to determine whether the effects seen in relation to saccharine were caused not by a contaminant in the saccharine production process but by the sweetener itself would have cost $\$ 500,000$ in 1980 . Merrill, supra note 3 , at 486 . The cost for bioassays can range up to $\$ 3$ million. Lyndon, Information Economics, supra note 6, at 1812-13 \& n.65. Dow Chemical Co. claims that "a complete battery of tests [] would cost more than $\$ 1$ million." Maugh, supra note 127, at 1205.

Duration is often the key element of the test. Animal studies testing one dioxin required at least five years at relatively high levels simply to register effects. Dow Chem. Co. v. Allen, 672 F.2d 1262, 1270-71 \& n.14 (7th Cir. 1982). Two years is a common National Cancer Institute protocol. Maugh, supra note 127, at 1200.

134. EPA, Carcinogen Risk Assessment, supra note 90, at 33,997-98. For a comparison of various dose-response assumptions, see Sielken, Some Capabilities, Limitations, and Pitfalls in the Quantitative Risk Assessment of Formaldehyde, in Risk Analysis in the Chemical Industry 74, 74-122 (Chemical Mfrs. Ass'n 1985). 
models of carcinogenesis are available for this extrapolation, but their predictions can vary by orders of magnitude. ${ }^{135}$ Dose-response modeling is now a highly sophisticated field, and large amounts of basic research go into developing biologically plausible response curves. However, confidence in the accuracy of any model is severely limited by the lack of firm understanding of the mechanics of carcinogenesis. ${ }^{136}$ More knowledge of the cancer process in various species and of these species' comparative metabolic pathways, DNA function, and inherent qualities is very much needed to improve this area of risk assessment. One must also extrapolate from animals to humans in all cases, ${ }^{137}$ and between routes of exposure in some. ${ }^{138}$

The third phase of quantitative risk assessment, exposure assessment, requires the investigator to identify sources of chemical exposure, exposure pathways, environmental fate, measured or estimated concentrations, and exposed populations. ${ }^{139}$ Exposure can be directly measured in the workplace or in ambient air and water, but often exposure tests can be even more difficult to design and carry out, as well as

135. See Paustenbach, supra note 124, at 391-96. The variance among estimates for trichloroethylene was colorfully described as "provid[ing] a range of uncertainty equivalent to not knowing whether one has enough money to buy a cup of coffee or pay off the national debt." Cothern, Coniglio \& Marcus, Estimating Risk to Human Health, 20 Envtl. Sci. \& Tech. 111, 115 (1986).

136. Doniger, supra note 10, at 510-11; see also Brennan, supra note 10 , at 509-10 (models require reliance on statistics, not observation). EPA's program to improve risk assessment has focused on dose-response models in order to improve their fidelity to biological reality. See EPA, Research to Improve Health Risk Assessments (RIHRA) Program 12-14 (1988) [hereinafter RIHRA].

137. See Paustenbach, supra note I24, at 397-99 (discussing relationship of animal to human toxicity). There appears to be a consensus that animal carcinogens should be treated as human carcinogens in the absence of clear indictions otherwise. This assumption, however, is beginning to come under serious attack. See Abelson, Editorial: Testing for Carcinogens with Rodents, 249 Science 1357, 1357 (1990); Ames \& Gold, Too Many Rodent Carcinogens: Mitogenesis Increases Mutagenesis, 249 Science 970, 970-71 (1990).

138. The uncertainty of drawing conclusions about ingestion of asbestos fibers from toxicology data based on inhalation was a central problem in the Reserve Mining case. Reserve Mining Co. v. EPA, 514 F.2d 492, 5I4-16 (8th Cir. 1975) (en banc) (unanimous decision), modified sub nom. . Reserve Mining Co. v. Lord, 529 F.2d 181 (8th Cir. 1976); see supra text accompanying notes 60-62.

139. EPA, Guidelines for Estimating Exposures, 51 Fed. Reg. 34,042, 34,043, 34,046-48 (1986) [hereinafter EPA, Estimating Exposures]; EPA, Proposed Guidelines for Exposure-Related Measurements, 53 Fed. Reg. 48,830, 48,83I (1988) (proposed Dec. 2, 1988) [hereinafter EPA, Exposure-Related Measurements]. One commentator has noted that EPA must greatly expand its toxic monitoring activities "to cope with the EPA's increased commitment to expand risk assessment ... and to implement [media]based controls for toxics." Whitney, The Case for Reforming the Environmental Protection Agency's Scientific Research Program and Establishing a Uniform National Laboratory Accreditation and Certification System, 9 Va. Envtl. L.J. 99, 129 (1989) (citing EPA, Availability, Adequacy, and Comparability of Testing Procedures for the Analysis of Pollutants Established Under Section 304(h) of the Federal Water Pollution Control Act (1988)). 
more expensive, than animal studies for toxicity. ${ }^{140}$ Because exposure cannot always be directly measured, inferences often must be drawn. ${ }^{141}$ A chemical can have many sources, and the routes of exposure to individuals can be convoluted. Basic research in the development of models and their verification and improvement are major information priorities. ${ }^{142}$ In addition, since the actual dose to the target organ differs from the exposure to the individual, quantification of exposure alone is insufficient. The relationship of exposure to dosage is unlikely to be simply linear, and it varies based on the route of exposure, metabolism, and identity of the target organ. Thus, pharmacokinetic models-the development of which requires basic research-increasingly are becoming an essential part of exposure assessment. ${ }^{143}$

In itself, risk characterization, the final step of quantitative risk assessment, does not entail major information needs or costs. However, measurement of a particular risk does not take place in a vacuum. Even putting aside the statutory requirements of considering costs and benefits, an "unreasonable" risk has meaning only in relation to other risks. EPA can make risk decisions about one risk only in light of some knowledge of others, ${ }^{144}$ and thus EPA must be prepared to perform risk assessments for numerous substances.

Given these information needs, we are a long way from having sufficient data to support a broad program of quantitative risk assessment. Professor Merrill observes:

Each of the foregoing steps in the evaluation of a toxic chemical depends critically on the availability of information. Whether the issue is a chemical's potential to induce cancer in

140. Merrill, supra note 3 , at 486 . The costs of exposure modeling and fate analysis tend to frustrate the approaches to pollution control that directly regulate the amount of pollution in a given medium, for example, air quality. McGarity, supra note 28 , at 206-07.

141. For example, air emission models are regularly used instead of the enormously expensive task of constant monitoring. See EPA, Estimating Exposures, supra note 139, at 34,043, 34,046-48; EPA, Exposure-Related Measurements, supra note 139, at 48,831 .

142. See Council on Environmental Quality, Environmental Quality: 20th Annual Report 98-113 (1990).

143. See Krewski, Murdoch \& Withey, The Application of Pharmacokinetic Data in Carcinogenic Risk Assessment, in 8 National Research Council, Pharmacokinetics in Risk Assessment: Drinking Water and Health 441, 446-50, 462-63 (1987); Whipple, supra note 90 , at $10,192-93$.

144. See Whipple, Redistributing Risk, Regulation, May/June 1985, at 37, 40-41 (occupational risk transfer). Comparison of many risks and the costs of reducing them is implicit in Professors Stewart and Ackerman's idea of a "risk portfolio," which seeks to achieve risk reduction in a rational and cost-effective manner by choosing which risks to reduce and which not. See Ackerman \& Stewart, supra note 20, at 1360-61; see also Huber, supra note 4, at 1025 (arguing that EPA often delays accepting new risks even though existing risks are worse). In addition, when EPA tackles one risk, it is affecting others, either by neglecting the other (due to limited resources) or by its choice of technology to reduce the present risk. 
mammals, the level of human exposure, or the benefits of its use, a regulator needs good data to reach a reliable answer. In their dependence on information, regulators of toxic chemicals are of course not unique, but the cost and time required to generate adequate data about even one feature of a chemical make their task distinctive. ... These obstacles will continue to impede regulatory decisions and will ultimately force regulators-and additionally, legislators and judges-to accept approximations and best guesses if they are to pursue, much less complete, regulation. 145

In light of these needs, the lack of information about the chemicals to which we are exposed is remarkable. By one estimate, we have virtually no toxicity data on eighty percent of the chemicals in use today. ${ }^{146}$ In its report entitled Toxicity Testing, the National Academy of Sciences studied the available information on a sample of substances representing industrial chemicals, food additives, and drugs and pesticides and their inert ingredients. ${ }^{147}$ Even though complete testing of each substance was deemed unnecessary for realistic regulatory purposes, the study found that testing was almost entirely absent except for shortterm data regarding a majority of drugs and pesticides. ${ }^{148}$ Of the relatively few chronic studies that have been done, many were of unacceptable quality. ${ }^{149}$ The report concludes:

[O]f tens of thousands of commercially important chemicals, only a few have been subjected to extensive toxicity testing and most have scarcely been tested at all. ... [I]t is clear that thousands or even tens of thousands of chemicals are legitimate candidates for toxicity testing related to a variety of health effects. ${ }^{150}$

Exposure assessment data-analytic methods, monitoring releases, monitoring consumption-are also needed.151 Overall, only a small minority of chemicals had been sufficiently studied to perform any kind of satisfactory health hazard assessment. ${ }^{152}$

145. Merrill, supra note 3 , at $485-86$. These views are echoed in Merrill, supra note 10 , at $16-17$.

146. The number of existing chemical products ranges into the hundreds of thousands, and the number regularly used in commerce is in the tens of thousands. About ten percent (over 90,000) of chemicals known to have toxic effects are listed in the Registry of Toxic Effects of Chemical Substances (RTECS) maintained by the National Institute of Occupational Safety and Health (NIOSH). NIOSH, U.S. Dep't of Health \& Human Services, Registry of Toxic Effects of Chemical Substances 1 (1985-86). The TSCA Inventory of Chemicals used in commerce lists 68,000 chemical substances as of the 1990 supplement. See EPA, Toxic Substances Control Act Chemical. Substance Inventory ii (Supp. 1990).

147. Toxicity Testing, supra note 6 , at $92-99$.

148. Id.

149. Id.

150. Id. at 13-14.

151. Id. at 120-24; Managing the Process, supra note 90, at 150-52.

152. Lyndon, Information Economics, supra note 6, at 1802-03. 
2. Identifying Regulatory Concerns. - Returning to the beginning of the regulatory process as a whole, an agency's initial identification of situations thought to call for regulatory action is likely to involve a tentative assessment of the presence of a risk to human health or the environment. Some problems are obvious: smog, flammable rivers, Love Canal, and Bhopal motivated the establishment of particular regulatory schemes in the first place. ${ }^{153}$ However, once regulatory goals are setclean air, clean water, and reduction of health risks from hazardous substances-their attainment depends on regulating activities whose effects are not as easily detected. It is no small matter to identify all of the constituents of air pollution or the long-term effects of chemicals, or to define the incidence of exposure to them in low concentrations. Regulation of carcinogens by the Consumer Product Safety Commission (CPSC) is a case in point. The concerns that originally motivated Congressional passage of the Consumer Product Safety Act ${ }^{154}$ were traumatic injuries like burns, cuts, suffocation, acute poisoning, and electrocution. ${ }^{155}$ The all-encompassing statutory language that empowered CPSC to adopt safety standards to "prevent or reduce an unreasonable risk of injury," 156 however, has led the agency to undertake the far more difficult task of regulating products that pose a cancer risk. ${ }^{157}$

While there is no need to quantify or to define precisely the risk at this first stage of the regulatory process, the agency needs information concerning the toxicity of the substances and the potential for human or environmental exposure. This is no more than the meaning of riskwithout either toxicity or exposure, there is little cause for concern and no compelling need for regulatory action. Yet even these data needs can be substantial. The RCRA and CERCLA listing provisions ${ }^{158}$ have been read to require information adequate for what amounts to a miniquantitative risk assessment. ${ }^{159}$

153. These events inspired, respectively, the Clean Air Act, the Clean Water Act, CERCLA, and the Emergency Planning and Community Right-to-Know Act of 1986 (EPCRA), 42 U.S.C. §§ 11001-11050 (1988).

154. 15 U.S.C. $\S \S 2051-2083$ (1988).

155. Merrill, CPSC Regulation of Cancer Risks in Consumer Products: 1972-1981, 67 Va. L. Rev. 1261, 1264-65 (1981).

156. 15 U.S.C. $\$ 2056$ (a) (1988) ("prevent or reduce an unreasonable risk of injury”); id. $\$ 2052$ (3) (" 'risk of injury' means a risk of death, personal injury, or serious or frequent illness").

157. See Merrill, supra note 155 , at 1265-67; see also Gulf South Insulation v. Consumer Prod. Safety Comm'n, 701 F.2d 1137 (5th Cir. 1983) (formaldehyde insulation rule). In 1981, Congress indirectly confirmed the applicability of the Consumer Product Safety Act to cancer. See 15 U.S.C. § 2077(a) (1988) (establishing advisory panel for "the chronic hazards of cancer, birth defects, and gene mutations").

158. See supra notes 39-41, 51-53 and accompanying text.

159. See, e.g., EPA, Reportable Quantity Adjustments: Radionuclides, 54 Fed. Reg. 22,524, 22,531-35 (1989) (to be codified at 42 C.F.R. pt. 302); EPA, Reportable 
3. Setting Priorities. - It is in the nature of most things, and certainly of regulatory budgets, that not enough resources exist to address all of the problems that have been identified as worthy of attention. Confronted with more regulatory demands than it can possibly manage, an agency must choose which to address first, which later, and which not at all. At a minimum, the agency must avoid paralysis in the face of competing demands for attention. Without clear priorities, it is likely to shift focus constantly, diffuse its efforts, and accomplish little. ${ }^{160}$ In highly visible areas of regulation, passing political fancy may set the agenda of an agency that lacks a firm idea of where it wants to go. ${ }^{161}$ The agency must evaluate or quantify the data available to it in order to identify emergencies requiring immediate action, to compare other problems in the same general area (e.g., which air pollutant to address first), and to compare among areas (e.g., air versus pesticide programs). ${ }^{162}$

Because EPA's responsibilities are spread among many statutes, deadlines, and Congressional committees, overall policy coordination is extraordinarily difficult and setting priorities extraordinarily important. ${ }^{163}$ In 1989 EPA published the results of a project designed to determine the most serious environmental problems facing three different regions of the country. ${ }^{164}$ The study revealed tbat the three highest health risks identified (radon, indoor pollution, and pesticide residues) receive minimal EPA resources. ${ }^{165}$ In contrast, two of the lowestranked risks (RGRA and CERCLA sites) are the subject of intense EPA efforts. ${ }^{166}$ This imbalance resulted, EPA concluded, from establishing priorities on the basis of public opinion and statutory mandates, rather than on the basis of relative risk. ${ }^{167}$

The most basic system for establishing priorities simply tells EPA

Quantity Adjustments, supra note 81 , at $8143-45$ (discussing methodology for hazardous substances in general and for carcinogens).

160. Shapiro \& McGarity, supra note 23, at 3, 15-20.

161. See J. Mendeloff, The Dilemma of Toxic Substance Regulation: How Overregulation Causes Underregulation at OSHA 143-47 (1988); Shapiro \& McGarity, supra note 23 , at $16-17$.

162. See Baram, Use of Comparative Risk Methods in Regulatory and Common Law, 13 Colum. J. Envtl. L. 1, 8-13 (1987) (describing benefits and difficulties of comparative risk assessment in setting agency priorities); Russell \& Gruber, Risk Assessment in Environmental Policy-Making, 236 Science 286, 287 (1987).

163. See Reducing Risk, supra note 120, at 1; Reilly, The Turning Point: An Environmental Vision for the 1990s, 20 Env't Rep. (BNA) 1386, 1389 (Dec. 8, 1989); Reilly, supra note 120 , at $3-4$.

164. See EPA, Comparing Risks and Setting Environmental Priorities: Overview of Three Regional Projects 1 (1989) [hereinafter EPA, Comparing Risks].

165. Id. at 62.

166. Id. at $62-65$.

167. Id. at 64; see also Lave, Risk Assessment and Regulatory Priorities, 14 Colum. J. Envtl. L. 307, 309-11 (1989) (coming to the same conclusion). EPA made similar findings in its earlier, more comprehensive study, Unfinished Business: A Comparative Assessment of Environmental Problems 91-99 (1987) [hereinafter EPA, Unfinished 
where to begin on its list of projects: which problem is worst? ${ }^{168} \mathrm{~A}$ simple system could focus either on the amount of exposure ${ }^{169}$ or on the degree of toxicity ${ }^{170}$ as plausible interpretations of "worst." While each alternative ignores one side of the risk equation, both render a rough approximation of relative risks. But identifying the worst problem is only the first step. EPA should also consider where its efforts will have the most effect. Thus, EPA must use a more complex priority system to avoid squandering limited funds on relatively minor or on intractable problems. ${ }^{171}$ Setting priorities to maximize the agency's impact on risk-that is, to be cost-effective-requires not only a fairly complete and precise evaluation of exposure and toxicity, but also application of cost and feasibility factors. ${ }^{172}$

The National Academy of Sciences devoted half of its study of regulatory information needs to developing priorities among the data gaps it found. On the basis that the "two key elements for screening are estimated human exposure and suspicion of toxic activity,"178 the Academy concluded that "the knowledge needed for unerring selection of the most important chemicals and tests is the same as the knowledge

Business], and in its Science Advisory Board's review of it. Reducing Risk, supra note 120 , at 3 .

168. In a few instances, Congress has instructed EPA to set specific priorities, for example, among Superfund cleanup sites, taking into account a large number of dataintensive considerations. See 42 U.S.C. $\$ 9605$ (a)(8)(B) (1988) (establishment of a National Priorities List); id. § 9604(i)(2) (ATSDR priority list of chemicals at NPL sites). TSCA requires EPA to establish testing priorities. 15 U.S.C. $\$ 2603(e)(1)(A)(1988)$.

169. OSHA's 1980 Cancer Policy rejected quantitative risk assessment as a basis for regulation of nonthreshold toxics, but accepted it for setting priorities. Even so, it placed the number of persons exposed and the levels of exposure at the head of its list of priority factors; only where adequate risk data existed was it factored in. OSHA, Occupational Carcinogens, supra note 102, at 5240-41, 5256.

170. TSCA gives testing priority to chemicals "known to cause ... or which are suspected of causing . . cancer, gene mutations, or birth defects." 15 U.S.C. $\S 2603(e)(1)(A)(1988)$. Likewise, EPA sets reportable quantities for carcinogens under CERCLA, 42 U.S.C. $\$ \S 9602$ (a) and 9603 based solely on toxicity. EPA, Reportable Quantity Adjustments, supra note 81, at 8145-46; cf. Ames, Magaw \& Gold, Ranking Possible Carcinogenic Hazards, 236 Science 271, 271 (1987) (using animal cancer tests to develop numerical index as guide to priority setting).

171. See EPA, Framework, supra note 90, at 7, 27, 33-35; Reducing Risk, supra note 120, at 16, 19-20; Morgenstern \& Sessions, Weighing Environmental Risks: EPA's Unfinished Business, Environment, July/Aug. 1988, at 14, 37-38.

An elaborate priority scheme can also (in theory) accomplish more complex goals like a "portfolio" approach to risks. See Ackerman \& Stewart, supra note 20, at 1360-61 (using cost-effectiveness to choose which risks to reduce).

172. One approach, called "scoring," assigus numerical scores to available data, which are combined to produce a single score that indicates relative toxicity, exposure, or overall risk. Toxicity Testing, supra note 6, at 221. Another approach, "mega-scoring," combines quantitative and qualitative evaluations. The agency assigns quantitative scores to its qualitative evaluation of available data, then uses these scores to rank substances. Shapiro \& McGarity, supra note 23 , at 21 .

173. Toxicity Testing, supra note 6 , at 14 ; see also id. at $211,215-22$ (identifying exposure and toxicity as the "key elements for screening"). 
resulting from a complete and accurate testing program for all chemicals."174 Establishing priorities on the basis of risk or cost-effectiveness need not and should not be as elaborate as a full-blown quantitative risk assessment, ${ }^{175}$ but it does require some data over the range of information used by quantitative risk assessment. Moreover, these data must be available for numerous chemicals or activities since setting priorities is a comparative activity. ${ }^{176}$

Like quantitative risk assessment, priority-setting systems themselves generate a data gap, which widens as the range of risks to be compared increases. EPA recently undertook an ambitious effort, entitled Unfinished Business, to establish priorities among all of the environmental problems that it regulates. ${ }^{177}$ The study identified thirty-one substantive areas of environmental concern and four types of risk, and attempted to arrive at quantitative estimates of each risk in each area. ${ }^{178}$ Firm conclusions, however, were precluded by a lack of knowledge about environmental processes, routes of exposure, extent of exposure, and the existence and severity of health effects. ${ }^{179}$ The report, therefore, called for the generation of more toxicity and exposure information and additional study of quantitative methods in aid of EPA's

174. 1d. at 205. EPA's newly revised Hazard Ranking System (HRS) for Superfund sites operates in precisely this way. EPA, Hazard Ranking System, 55 Fed. Reg. 51,532 , 51,532-34 (1990) (to be codified at 40 C.F.R. pt. 300 app. A) (proposed Dec. 23, 1988). CERCLA requires consideration of both toxicity and exposure factors in the HRS. 42 U.S.C. § 9605(a)(8)(A) (1988); see Eagle-Picher Indus. v. EPA, 759 F.2d 905, 921-22 (D.C. Cir. 1985) (approving HRS methodology); cf. Shapiro \& McGarity, supra note 23, at 20-21 (describing possible factors for setting priorities under OSHA).

175. As with information development generally, the costs of setting priorities can exceed the savings in efficiency. See Siegel, Integrating Public Health into Superfund: What Has Been the Impact of the Agency for Toxic Substances and Disease Registry?, 20 Envtl. L. Rep. (Envtl. L. Inst.) 10,013, 10,015 (Jan. 1990) (arguing that toxicology profiles based on incomplete information are adequate for ranking Superfund sites). In establishing HRS, EPA made a point of stating that the priority-setting process precedes risk assessment and that it "provides a measure of relative rather than absolute risk. ... [T] hus, [it] is not designed to be used as a quantitative risk assessment." EPA, Hazard Ranking System (HRS) for Uncontrolled Hazardous Substance Releases; Appendix A of the National Oil and Hazardous Substances Contingency Plan, 53 Fed. Reg. 51,962, 51,963-64 (1988) (proposed rule) (citing H.R. Conf. Rep. No. 962, supra note 56, at 199-200, reprinted in 1986 U.S. Code Cong. \& Admin. News at 3292-93 (Conference Report on SARA)).

176. Cf. Latin, Good Science, supra note 4, at 106-07 (questioning practical ability of agencies to undertake "portfolio" approach to risk).

177. EPA, Unfinished Business, supra note 167 . For a general review of the study by its leader, see Morgenstern \& Sessions, supra note 171, at 14.

178. Morgenstern and Sessions characterize the method as building on EPA's development of quantitative methods in setting cancer priorities. Morgenstern \& Sessions, supra note 171 , at 17,34 .

179. See EPA, Unfinished Business, supra note 167, at 2-3 ("Because of these uncertainties the results of this project should be regarded as not analytically pure but rather as judgmentally correct...."). The NAS Toxicity Testing report reached a similar conclusion. Toxicity Testing, supra note 6, at 215-16, 223, 296. 
priority-setting function. ${ }^{180}$

4. Enforcement. - Enforcement is the final phase of the regulatory process. Its complexity and difficulty should not be underestimated. Nevertheless, by and large it requires simpler, better understood types of information than other stages of the regulatory process. ${ }^{181}$ While standard setting demands highly advanced and often controversial projections of health effects and technology, enforcement at its best relies on generally accepted and relatively inexpensively obtained data to determine whether the standard is being met. For example, it is far simpler to ensure compliance with structural requirements for a landfill than it is to establish the structural requirements in the first place.

Although this Article will not treat enforcement in detail, three points should be noted. First, the data needs of enforcement depend on the regulatory criteria chosen by the agency. 1t is relatively easy to determine whether a mandated piece of equipment has been installed and is operational; it is often difficult and expensive to measure actual discharges, emissions, or other releases into the environment. ${ }^{182}$ To the extent that a statute takes the latter approach, it requires extensive monitoring activity to enforce. ${ }^{183}$ Second, as EPA regulates more and more toxic substances and science is better able to detect smaller and smaller amounts of them, there has been an explosive growth in the demand for monitoring data. ${ }^{184}$ Though the information sought usually is not at the frontiers of scientific knowledge, it is nevertheless highly sophisticated, expensive, and central to a mandatory regulatory scheme. ${ }^{185}$ Third, monitoring data and other enforcement information overlap the information needs of quantitative risk assessment. In evaluating risk to set regulatory standards, EPA requires exposure data from, or parallel to, enforcement activity.

5. The Impact of Right-to-Know Laws. - The recent popularity of right-to-know statutes creates an additional, albeit indirect, demand for information concerning toxic substances. The main federal contributions in this area are the I983 OSHA Hazard Communication Stan-

180. See EPA, Unfinished Business, supra note 167, at 98-99; Reducing Risk, supra note 120 , at 8,18 .

181. Professor Whitney divides the universe of EPA's research into "Type-A" and "Type-B." The former is exemplified by research used to set standards; it is highly complex and at the frontiers of scientific knowledge. Type-B research is used to enforce standards and to measure quality control within programs. Whitney, supra note 139 , at $100-01$.

182. See S. Breyer, supra note 22, at 105-07; McGarity, supra note 28, at 225.

183. See generally S. Breyer, supra note 22 , at 105-06 (contrasting design and performance standards).

184. Whitney, supra note 139 , at $127-28$. The toxics statutes specifically grant broad monitoring authority to EPA. See 7 U.S.C. $\S 136 \mathrm{r}$ (c) (1988) (FIFRA); 15 U.S.C. $\S 2609$ (a) (1988) (TSCA); 42 U.S.C. § 6934(a), (d) (1988) (RCRA); id. § 9604(b)(1) (CERCLA).

185. See Whitney, supra note 139 , at $100-01,126-42$. 
dard, ${ }^{186}$ which applies to workplace hazards, and the Emergency Planning and Community Right-to-Know Act of 1986 (EPCRA), ${ }^{187}$ which requires disclosures to the public as a whole. The Hazard Communication Standard uses material safety data sheets (MSDS) to inform employees of the identity, characteristics, health effects, and estahlished exposure limits of hazardous materials that they may encounter in their workplaces. ${ }^{188}$ EPCRA adopts the MSDS as the cornerstone of its public information provisions. ${ }^{189}$ ln addition, it requires the reporting of off-site spills of listed chemicals, an inventory of chemicals at industrial facilities, and calculation of releases of toxic substances from normal operations. ${ }^{190}$ Virtually all of these data are available to the public, with the exception of trade secrets. ${ }^{191}$

Both utilitarian and entitlement rationales have been advanced to support these provisions. ${ }^{192}$ The Hazard Communication Standard emphasizes utilitarian reasons: additional information encourages workers to take available precautionary measures and to develop new ones, ${ }^{193}$ and also assists them in seeking compensation for toxic injuries through the tort system. ${ }^{194}$ EPCRA's main utilitarian aim is local emergency planning. ${ }^{195}$ Its data also can be used to establish and re-

186. 29 C.F.R. $\S 1910.1200$ (1990); OSHA, Hazard Communication, 48 Fed. Reg. 53,280 (1983) (to be codified at 29 C.F.R. pt. 1910).

187. 42 U.S.C. $\S \S 11021-11023,11044$ (1988) (EPCRA was enacted as title 111 of SARA).

About half of the states have enacted right-to-know laws. See Hjelm, Environmental Law 1: Worker and Community Right to Know Laws, 1987 Ann. Surv. Am. L. 701, 701 (1989). EPCRA was based in part on the New Jersey right-to-know statute. S. Rep. No. 11, 99th Cong., 1st Sess. 9-12 (1985).

188. 29 C.F.R. $\S 1910.1200(\mathrm{~g})(1989)$. The promulgation of a standard to ensure that employees are "apprised of all hazards to which they are exposed, relevant symptoms and appropriate emergency treatment, and proper conditions and precautions of safe use or exposure" was mandated by section 6(b)(7) of the Occupational Safety and Health Act of 1970, 29 U.S.C. $\$ 655$ (b)(7) (1988).

189. 42 U.S.C. § 11021 (a)(1) (1988).

190. 1d. $\$ \S 11004,11022(a), 11023(a)$.

191. 1d. $\$ \S 11023(\mathrm{~h}), 11042,11044$.

192. These rationales are contrasted in Schroeder, supra note 77, at 505-10, $553-62$, which recommends some compromise of the two.

193. Workers' unwillingness to use protective gear and devices, the agency suggested, would diminish if they knew the risks they faced. OSHA, Hazard Communication, supra note 186 , at $53,324,53,327-28$.

194. Disclosure of this information makes it easier for exposed individuals to establish the existence of exposure and related effects. Rogers, The Potential Role of Superfund in Toxic Tort Litigation, Nat. Resources \& Env't, Spring 1988, at 13, 47. This assistance to plaintiffs, OSHA points out, helps to internalize injury costs previously externalized by industries using toxic chemicals unsafely. OSHA, Hazard Communication, supra note 186 , at $53,323-24$.

195. 42 U.S.C. $\$ \S 11001-11005$ (1988); see also 132 Cong. Rec., S14,911 (daily ed. Oct. 3, 1986) (remarks of Sen. Lautenberg, a principal sponsor of EPCRA). Similarly, in an emergency, health workers must have access to identity and toxicity information to treat exposure. See 42 U.S.C. \& 11043(b) (1988); S. Rep. No. 11, supra note 187, at 10; 
vise laws and regulations, ${ }^{196}$ to influence lawmakers and regulators, ${ }^{197}$ and to negotiate or litigate with emitters. ${ }^{198}$ The predominant rhetoric of EPCRA, however, is not utilitarian but, as its name suggests, "a fundamental right to know about what chemicals, toxic chemicals, are being released into [the American people's] environment hour after hour, day after day, year after year." 199

What the public is to do with the information to which it has a right is less clear. The knowledge of the presence of hazardous substances in the community seldom brings with it the ability to do anything about

H.R. Rep. No. 253, 99th Cong., 1st Sess., pt. 1, at 59, reprinted in 1986 U.S. Code Cong. \& Admin. News 2835, 2841; H.R. Conf. Rep. No. 962, supra note 56, at 281, reprinted in 1986 U.S. Code Cong. \& Admin. News at 3374.

196. Early reports under EPCRA are being used for precisely this purpose. See House Toxics Control Measure Introduced, Data Tying Emissions to Health Effects Released, 20 Env't Rep. (BNA) 436, 437 (June 16, 1989) [hereinafter House Toxics Control Measure] (remarks of Rep. Waxman); id. at $467-68^{\circ}$ (remarks of NRDC); Data from EPCRA Emissions Reporting Called "Startling” by Environmental Agency, 19 Env't Rep. (BNA) 2628, 2629 (Apr. 21, 1989) (Sen. Lautenberg to respond to new data with air toxics control legislation).

197. See, e.g., Superfund Provisions: Community Right-to-Know and Cleanup of Abandoned Hazardous Wastesites Located at Federal Facilities: Hearing Before the Subcomm. on Commerce, Transportation, and Tourism of the House Comm. on Energy and Commerce, 99th Cong., 1st Sess. 8 (1985) [hereinafter SARA Hearings] (statement of Darby Nelson, Minn. State Rep.); id. at 15 (Peggy Ladner, Midwest Director, Clean Water Action Project); Chemical Manufacturers Lead Industries in Toxic Substances Release, EPA Reports, 20 Env't Rep. (BNA) 467, 467 (June 23, 1989); House Toxics Control Measure, supra note 196, at 437; see also 48 Fed. Reg. 53,280, 53,324 (data are useful to OSHA in regulation).

198. SARA Hearings, supra note 197, at 14, 24 (remarks of Peggy Ladner); Hadden, Right-to-Know: What It Can Mean for Citizens, EPA J., May/June 1989, at 13, 14-15; Lyndon, Information Economics, supra note 6, at 1829 n.130.

199. SARA Hearings, supra note 197, at 3 (Rep. Sikorski) (emphasis added); accord id. at 23 (Rep. Sikorski); id. at 9 (Rep. Nelson); H.R. Conf. Rep. No. 962, supra note 56, at 281, reprinted in 1986 U.S. Code Cong. \& Admin. News at 3374; see also N.J. Stat. Ann. § 34:5A-2 (West 1988) ("inherent right to know"); Initiative Measure, Proposition 65, Nov. 4, 1986, § 1, reprinted in Cal. Health \& Safety Code § 25249.5 historical note (West Supp. 1990) (declaring "right[] ... [t]o be informed"). The idea of a right to know is addressed by several commentators, see, e.g., Lyndon, Information Economics, supra note 6 , at 1797, 1829-30 (right-to-know has its roots in informed consent and duty to warn); Schroeder, supra note 77, at 509-10 (nonconsensual risks resulting from lack of information violate right to personal security and autonomy), and courts, see, e.g., New Jersey State Chamber of Commerce v. Hughey, 774 F.2d 587, 590-93 (3d Cir. 1985) (distinguishing general statutory right to know, designed to protect all residents, from safety-based employee disclosure provisions of OSHA), cert. denied, $109 \mathrm{~S}$. Ct. 3246 (1989); accord Manufacturers Ass'n of Tri-County v. Knepper, 801 F.2d 130, 133-34 (3d Cir. 1986), cert. denied, 108 S. Ct. 44 (1987); Ohio Mfrs. Ass'n v. City of Akron, 801 F.2d 824, 825 (6th Cir. 1986), cert denied, 108 S. Ct. 44 (1987).

A more subtle version of this argument is that the pervasive scientific uncertainty concerning toxic substances results in risk decisions being not simply factual but highly value-laden. Under these circumstances, citizens have much to contribute to value and policy choices. See Stenzel, supra note 14, at 551-56. 
them. ${ }^{200}$ Supporters of EPCRA suggested that it provides communities with "the quantitative information necessary to use this data effectively" and would "allow communities to gauge the potential long-term chronic health effects of toxic chemical releases."201 At least in theory, workers can take precautions, bargain with their employers for safety, suggest safer procedures, refuse certain work, or even change jobs. Citizens generally, on the other hand, are in a much poorer position to reduce risk themselves. Moreover, it is questionable whether consumers or workers are in a position to make intelligent use of the information. ${ }^{202}$ Nevertheless, by providing toxicity and exposure information parallelling quantitative risk assessment, ${ }^{203}$ the data requirements of the right-to-know laws encourage individuals to undertake their own,

200. An individual can, of course, engage in the lobbying, negotiation, or litigation mentioned above, but the average citizen is unlikely to be able to take meaningful safety precautions. The only remaining response is to move away from the source of danger. See N.J. Stat. Ann. \& 34:5A-2 (West 1988) ("individuals have an inherent right to know ... so that they can make reasoned decisions and take informed action concerning their employment and their living conditions"); see also OSHA, Hazard Communication, supra note 186 , at $53,323,53,328$ (suggesting that workers could change jobs to achieve "better matches between the risk preferences of workers and true job risks"). But encouraging mass emigration from industrial areas seems an unrealistic and extremely undesirable social policy.

201. Cf. H.R. Rep. No. 253, supra note 195, pt. 1, at 292, reprinted in 1986 U.S. Code Cong. \& Admin. News at 2967 (separate and dissenting views of Reps. Florio, Richardson, Markey, Bates, Sikorski, Waxman, Wirth, Leland, Scheuer, and Mikulski arguing for inclusion of inventory data, as eventually occurred). The conference committee noted that the MSDS is intended to have both qualitative information (e.g., toxicity) and quantitative information. H.R. Conf. Rep. No. 962, supra note 56, at 289-95, reprinted in 1986 U.S. Code Cong. \& Admin. News at 3382-88.

202. See Blomquist, The Logic and Limits of Public Information Mandates Under Federal Hazardous Waste Law: A Policy Analysis, 14 Vt. L. Rev. 559, 587-88 (1990); Latin, Consumer Decisionmaking, supra note 5, at 224-28. Because consumers cannot deal well with raw data, California's Proposition 65, see infra notes 260-265 and accompanying text, translates hazard information into clear and simple signals-a ban on substances in drinking water and notification of all exposures above a threshold level. Roe, What Kind of Data Does the Public Need?, EPA J., May/June 1989, at 10, 11; cf. Fitts, Can Ignorance Be Bliss?: Imperfect Information as a Positive Influence in Political Institutions, 88 Mich. L. Rev. 917, 939-46 (1990) (arguing that political parties can limit information to promote rational decision making). But see Black, California's Community Right-to-Know, 16 Ecology L.Q. 1021, 1061-64 (1989) (expressing concern that professionalization of right-to-know has removed it from its roots in public awareness); Stenzel, supra note 14, at 563-71 (arguing that public needs access to risk assessments to evaluate general warnings).

203. See 29 C.F.R. $\S 1910.1200$ (g) (1990). In addition, SARA enacted not only EPCRA but also amendments to CERCLA that required the Agency for Toxic Substances and Disease Registry (ATSDR) to develop nontechnical "toxicological profiles." See 42 U.S.C. \& 9604(i)(3) (1988); HHS \& EPA, Guidelines for Development of Toxicological Profiles, 52 Fed. Reg. 12,870, 12,870-74 (1987) (proposed Apr. 17, 1987). The model outline for toxicological profiles reads like the data requirements of quantitative risk assessment, including a general discussion of "the relative benefit to society versus the risk" of the chemical being profiled. See id. at 12,873-74. The toxicological profile for lead is reprinted in $2 \mathrm{M}$. Dore, Law of Toxic Torts 26-19-26-213 (1990). 
informal risk assessments. ${ }^{204}$

Once the public appetite for risk information is whetted by a sense of entitlement to it, and once data gaps are publicly identified, ${ }^{205}$ it is hard to see how government and industry can avoid additional demands for more specific information regarding the chemicals. ${ }^{206}$ If, as some advocate, ${ }^{207}$ risk assessments are routinely to be made available to the public, and if these risk assessments appropriately disclose their data gaps and assumptions, the public would be acutely aware of just how little is known about the chemicals to which it is exposed. Having opened the door to public scrutiny and comment on the risks associated with chemicals, the goverument will be called upon, with or without the unreasonable risk standard, to develop large amounts of the kind of information used in quantitative risk assessment. And when that happens, the gap between existing and desired information will widen rather than close.

\section{INFORMATION ACQUisition IN GENERAL}

Toxic substances and the regulatory process make enormous information demands upon EPA. Regulatory policies, such as the unreasonable risk standard, might be altered to reduce the demands, but substantial residual information needs would remain. Therefore, the task of environmental law is not only to establish the substantive policy and regulatory structures for managing toxic substances, but also to provide the information that the regulatory structures need in order to operate. Likewise, our task is not only to improve decision making by environmental regulators, but also to consider ways to develop the needed data. This Part first discusses the lack of market and private law incentives to produce the necessary information. It then evaluates the available governmental or public law strategies for obtaining risk data, dividing them into four types of regulatory techniques.

\section{A. Information and Market Failure}

Most marketplace actors are unlikely to be good sources of toxic risk data. Toxicology information is too expensive for workers and consumers (or even unions and consumer organizations) to gener-

204. See H.R. Rep. No. 253, supra note 195, pt. 1, at 116 , reprinted in 1986 U.S. Code Cong. \& Admin. News at 2898 (stating that EPCRA calls for "the type of information which will assist citizens in assessing the potential hazards [i.e., the risks] associated with particular chemicals"); Stenzel, supra note 14, at 551, 565-66 ("people make many risk-related decisions on an individual basis").

205. Data gaps must be specifically identified in an MSDS, 29 C.F.R. $\S 1910.1200(\mathrm{~g})(3)(1990)$, and in a toxicological profile, 42 U.S.C. $\S 9604(\mathrm{i})(3)(\mathrm{B})-(\mathrm{C})$ (1988).

206. See Hayes, New Life, supra note 9 , at 58 .

207. See Stenzel, supra note 14 , at 571-84. 
ate. ${ }^{208}$ Exposure and cost data may simply be impossible for these persons to obtain. Moreover, the benefit to any individual of developing the information is small. The information is a public good (that is, it is nonexcludable), which reduces to practically nil any return to these persons on investment in research. ${ }^{209}$ Accordingly, as a general rule no individual or group has sufficient financial resources, opportunity, or stake to make the generation of data worthwhile.

In contrast, industries that produce and use chemicals ordinarily are in the best position to provide or obtain toxicity and exposure data most cheaply and accurately. They have the greatest familiarity with their products' characteristics and the occasions for exposure to them, and they have the most opportunities to learn about the chemicals. Moreover, the prospects of liability for dangerous products and of consumer rejection of dangerous chemicals should provide strong incentives for industry to use its position to learn as much as possible about potential liability.

Historically, however, the decentralized, unregulated market has not effectively produced information regarding toxic chemicals, largely because those chemicals' salient characteristics (uncertainty of mechanism and effect, rarity and long latency of effect, and collective risk) reduce present appreciation of chronic risks. This makes toxic risks easy to ignore. ${ }^{210}$ Because these characteristics also limit tort actions and hamper governmental regulation, the liability incentive is substantially reduced. A chemical's latent toxic effects are hardly a point in its favor in the market, and such information could become the basis for liability or regulation. Therefore, industry has real incentives to avoid either creating toxic risk data or disclosing the data it already has. Since those outside the industry are even less likely to be able to develop liability-producing data, the benefits of knowing about a chemical's chronic effects may seem slight or negative compared to the very high direct costs of testing.

Tort law does not significantly alter the market in this respect. The emerging field of toxic torts is characterized by its lack of information for decision making, and not by its ability to generate data. Again, the industrial defendant is typically in the best position to create the neces-

208. See Latin, Consumer Decisionmaking, supra note 5, at 223-33.

209. See id. at 215-22, 228-33; Lyndon, Information Economics, supra note 6, at 1809-17; Schroeder \& Shapiro, supra note 5, at 1237-39; see also Gillette \& Krier, supra note 5, at 1046-54 (discussing "access bias" problem that occurs when expense, difficulty of proving injury, and free rider effects create disincentives to individual or class suits regarding public risks).

210. What follows in the text is a thumbnail sketch. The causes and effects of market failure with regard to toxic substances are more fully considered in $P$. Asch, supra note 2, at 48-56; Gillette \& Krier, supra note 5, at 1036-42; Latin, Consumer Decisionmaking, supra note 5, at 218-22; Lyndon, Information Economics, supra note 6, at 1810-17, 1832- 33; see also Schroeder \& Shapiro, supra note 5, at 1245-54 (criticizing tort law and workers' compensation for failing to reinternalize such costs). 
sary data, but its incentives are the reverse. In the absence of dramatic changes to encourage defendants to generate and disclose potentially inculpatory toxicity evidence, tort law is unlikely to be a major factor in creating toxics data. ${ }^{211}$ In addition, the judicial process is institutionally ill-suited for generating useful toxics information. The usual sources of information are highly selective and biased on each side, and courts have little ability to investigate independently, due to lack of expertise, funds, and legal authority. ${ }^{212}$ Substantive rules of tort liability, such as causation and the requirement of actual harm, limit resort to litigation; therefore, cases are too few and too random to develop a comprehensive data base. ${ }^{213}$ Not surprisingly, those who have studied tort law's information effects on toxics data have recommended governmental disclosure, research, or regulatory schemes to remedy the ineffectiveness of the market and the tort law system. ${ }^{214}$

\section{B. A Taxonomy of Regulatory Techniques}

If market and private law incentives do not produce the information needed to regulate toxic substances effectively, then the government must take a part in doing so. Consequently, data acquisition is a key component in all of the toxics statutes. In discussing the regulatory techniques in these statutes, reference will be made to six qualities that a good system of information acquisition should embody. Newness of data must be the key criterion for evaluating a system desigued to fill a void in information. Because massive quantities of toxicity and exposure data are simply absent for toxic substances, information acquisition that taps only sources of existing information has limited utility. Cost is essential to the feasibility of the technique. The absolute cost of generating information, together with the allocation of the cost, determines how much information can be expected to be generated. The quality of the data should be adequate to form a valid basis for scientific and policy judgments. Among other things, the regulator must be confident of the data's objectivity and absence of bias. The technique should be sufficiently flexible and precise to produce data that is rele-

211. For a model statute adopting these strategies, see Trauberman, Statutory Reform of "Toxic Torts": Relieving Legal, Scientific, and Economic Burdens on the Chemical Victim, 7 Harv. Envtl. L. Rev. 177, 224-30, 281-82 (1983).

212. See Latin, Consumer Decisionmaking, supra note 5, at 235-39; Lyndon, Information Economics, supra note 6, at 1817-18; Schroeder \& Shapiro, supra note 5, at 1294-97; see also Elliott, Goal Analysis, supra note 5, at 1372-76 (given little information, regulatory system can make better decisions than courts).

213. Cf. Huber, supra note 5, at 317-18 (tort system's choice of cases is not governed by availability of information).

214. See, e.g., Latin, Consumer Decisionmaking, supra note 5, at 223-33 (noting superiority of governmental information development); Lyndon, Information Economics, supra note 6 , at $1835-55$ (recommending program of privately funded governmental research and data collection); Schroeder \& Shapiro, supra note 5, at 1295-96 (advocating wider use of information disclosure requirements). 
vant to the agency's concerns. Timing is also important. The receipt of the data must conform at least roughly with the agency's agenda and priorities. Information acquisition should not become a source of undue delay in the regulatory process, either by delaying approval of products or by hindering the imposition of restrictions. Finally, a technique must have sufficient coverage to acquire information regarding as many substances as possible, since the inadequacy of data is by no means confined to a small group of chemicals.

1. Compilations of Existing Data. - A book misshelved in a large library might as well not exist for the person looking for it. The same is true of uncollected, uncatalogued, or undisclosed information. The first step of a risk assessor is to collect all available data, but these data are often scattered throughout libraries, government agencies, laboratories, and industry records. In such a case, the initial task is not to generate new data but to collect what already exists.

Regulators can attack this problem in a number of ways. EPA and other agencies have assembled available information in libraries, databases, clearinghouses, and bibliographies. ${ }^{215}$ EPA has long recognized the need for, and has a legislative mandate in TSCA to assemble, a national data system for toxic substances. ${ }^{216}$ TSCA also requires EPA to "compile, keep current, and publish" a comprehensive inventory of all chemicals reported as being manufactured or processed in the United States. ${ }^{217}$ Using recent advances in telecommunications and

215. See Toxicity Testing, supra note 6, at 51-54. A "central reference library" of solid and hazardous waste management is established under RCRA. 42 U.S.C. $\S 6983$ (b) (1988). Similar collections have been developed under other statutes. The Registry of Toxic Effects of Chemical Substances (RTECS) is produced by NIOSH and as of January 1989 contained information on 98,000 chemicals. NIOSH, supra note 146, at 1 . The editor of RTECS estimates that there are approximately 250,000 chemicals with extant (though rarely reliable) toxicity data. See id. at 29. The Injury Information Clearinghouse established by the Consumer Product Safety Act, 15 U.S.C. $\S 2054$ (a) (1988), permits studies by CPSC of the risks of products, and public access allows individual use of the data, for example, in product liability suits. See also Stenzel, supra note 14, at 571-88 (recommending establishment of clearinghouse for risk assessments). EPA officials have also suggested the establishment of a distinct, unified organization to coordinate and manage environmental data. Habicht Says EPA Will Factor Risk into New Multimedia Approach to Regulation, 13 Chem. Reg. Rep. (BNA) 1226, 1226 (Dec. 8, 1989). In bills to elevate EPA to Cabinet level, Congress considered a similar proposal with the aim of avoiding political influence on environmental statistics. See S. 2006, 101st Cong., 2d Sess., 136 Cong. Rec. S122 (daily ed. Jan. 23, 1990); H.R. 3847, 101 st Cong., 2d Sess. (1990); Senate Committee Adopts Legislation to Establish EPA as Cabinet-Level Agency, 20 Envt. Rep. (BNA) 1845, 1845 (Mar. 9, 1990); infra note 248.

216. See 15 U.S.C. $\$ 2609$ (b) (1988). See also Lyndon, Information Economics, supra note 6, at 1843-45 (discussing Council on Environmental Quality database recommendations); Decision Making, supra note 6, at 9, 76 (interagency coordination of existing systems).

217. 15 U.S.C. $\$ 2607$ (b)(1) (1988); see Hayes, New Life, supra note 9, at 60-61. In practice, this inventory contains little new data. See Lyndon, Information Economics, supra note 6 , at 1823 . 
electronic media, EPA has established computer compilations on a wide range of toxics issues. ${ }^{218}$ Right-to-know laws also compile existing information by collecting in one place basic toxicity and exposure information for public use. ${ }^{219}$

A more elaborate approach to compilation is to conduct or commission reports that assemble and analyze existing data on a particular chemical. The major federal effort of this kind is the establishment of the Agency for Toxic Substances and Disease Registry (ATSDR) as part of the CERCLA cleanup process. ${ }^{220}$ Its Superfund duties are to establish a ranked list of one hundred hazardous substances commonly found at Superfund sites, ${ }^{221}$ to create toxicological profiles of those substances based on existing information, ${ }^{222}$ and to perform health assessments of all sites on the National Priorities List. ${ }^{223}$ ATSDR uses

218. Toxic substances databases include Toxline from the National Library of Medicine, a Pesticide Monitoring Inventory, HAZARDLINE regarding workplace chemicals, the Toxic Chemical Release Inventory (TRI) by the National Library of Medicine and EPA based on the 42 U.S.C. $\$ 9603$ reporting requirements, and the Integrated Risk Information System (IRIS), which summarizes key hazard identification and dose-response data. The newest is CERCLIS (Comprehensive Environmental Response, Compensation, and Liability lnformation System), for use in evaluating and prioritizing potential Superfund cleanup sites. See 42 U.S.C. § 9616(a) (1988); National Contingency Plan, supra note 57, at 8844 (to be codified at 40 C.F.R. $\$ 300.420$ ). See generally EPA, Guide to EPA Hotlines, Clearinghouses, Libraries, and Dockets (1990) (listing EPA information resources available to the public).

219. See supra notes 186-199 and accompanying text. One commentator claims that "EPCRA has become the government's greatest tool for gathering and disseminating information related to potential or actual releases of chemicals into the environment." Finto, Regulation by lnformation Through EPCRA, Nat. Resources \& Env't, Winter 1990, at 13, 13.

220. See 42 U.S.C. $\$ 9604$ (i) (1988). ATSDR is also incorporated into the recent amendment of RCRA. Id. § 6939a(c). ATSDR was originally established by CERCLA in 1980, but the agency was not constituted until 1983. See Environmental Defense Fund, Inc. v. Heckler, 13 Envtl. L. Rep. (Envtl. L. Inst.) 20,630, 20,630 (D.D.C. May 27, 1983). The nearly total absence of activity by ATSDR, however, led Congress in 1986 to clarify ATSDR's function and to establish a set of action-forcing deadlines for specific projects for the agency. See H.R. Rep. No. 253, supra note 195, pt. 5, at 27-37, reprinted in 1986 U.S. Code Cong. \& Admin. News at 3151-60 (SARA); S. Rep. No. 631, 98th Cong., 2d Sess. 14-24 (1984). EPA still tends to minimize ATSDR's role. Siegel, supra note 175 , at 10,018 .

For general overviews of ATSDR's activities, see Johnson, Health Effects of Hazardous Waste: The Expanding Functions of the Agency for Toxic Substances and Disease Registry, 18 Envtl. L. Rep. (Envtl. L. Inst.) 10,132 (1988) [hereinafter Johnson, Health Effects]; Johnson, Implementation of Superfund's Health-Related Provisions by the Agency for Toxic Substances and Disease Registry, 20 Envtl. L. Rep. (Envtl. L. Inst.) 10,277 (1990) [hereinafter Johnson, Implementation] (Barry Johnson is Assistant Administrator of ATSDR); Rogers, supra note 194, at 13-14; Siegel, supra note 175, at 10,013-17.

221. 42 U.S.C. § 9604(i)(2) (1988).

222. 1d. \& 9604(i)(3).

223. Id. § $9604(\mathrm{i})(6)$. 
available data in its analyses, ${ }^{224}$ identifies gaps in the data, and arranges to fill these gaps. ${ }^{225}$ However, the agency has little money to do its own testing ${ }^{226}$ and no authority to demand even existing information. ${ }^{227}$

EPA also is authorized by TSCA to gather, as opposed merely to compile, existing information. First, the premanufacture notification (PMN) process, unique to TSCA, requires a manufacturer to notify EPA before commencing commercial production of a new chemical and to supply basic information on the chemical's identity and characteristics, production and exposure, and health effects. ${ }^{228}$ EPA has up to ninety days to respond; if it takes no action, the chemical can be manufactured. ${ }^{229}$ However, a study of the content of PMN's by the Congressional Office of Technology Assessment revealed that the toxicity information they contained was extremely limited. About half of the PMNs studied contained none at all, and less than twenty percent included data on long-term toxicity. ${ }^{230}$ Second, under section 8 of TSCA, which has analogues in other statutes, EPA may require the chemical industry to keep records of "significant adverse reactions ... alleged to have been caused" by a regulated chemical, ${ }^{231}$ to report the

224. ATSDR depends on existing data, see id. § 9604(i)(6)(F); ATSDR/HHS, Health Assessments and Health Effects Studies of Hazardous Substances Releases and Facilities, 55 Fed. Reg. 5136, 5140 (1990) (to be codified at 42 C.F.R. § 90.8), such as information developed in the RI/FS stage of Superfund action, see 42 U.S.C. $\S 9604(a)(1)$, (b); Jobnson, Health Effects, supra note 220, at 10,133, TSCA data collections, see Siegel, supra note 175 , at 10,014 , exposure information developed under RCRA, see 42 U.S.C. $\$ 6939 \mathrm{a}(\mathrm{a})$, and, of course, begging. See ATSDR, Request for Comments on Chemicals Nominated for Toxicological Evaluation, 53 Fed. Reg. 10,569, 10,569-70 (1988) (requesting interested persons to submit exposure, production, and toxicological data concerning eight chemicals); HHS/EPA, Notice of the First Priority List of Hazardous Substances That Will Be the Subject of Toxicological Profiles, 52 Fed. Reg. 12,866, 12,870 (1987) (request for voluntary submissions).

225. See 42 U.S.C. \& 9604 (i)(5) (1988).

226. The statute provides, "It is the sense of the Congress that the costs of [ATSDR] research programs . . . be borne by the manufacturers and processors of the hazardous substance in question . . ." 1d. \$9604(i)(5)(D). The Senate apparently originated the idea that the relevant companies should reimburse these costs. See $\mathrm{S}$. Rep. No. 11, supra note 187 , at 33 . Without specific authority to impose testing costs, however, ATSDR must rely on other statutes to obtain information. See 42 U.S.C. $\S 9604(\mathrm{i})(5)(\mathrm{D})$.

227. See H.R. Rep. No. 253, supra note 195, pt. 1, at 84, reprinted in 1986 U.S. Code Cong. \& Admin. News at 2866 (means by which EPA Administrator must prepare toxicological profiles); id., pt. 5, at 30, reprinted in 1986 U.S. Code Cong. \& Admin. News at 3153 (health assessments rely mainly on EPA information and literature searches).

228. See 15 U.S.C. $\S 2604$ (a), (d) (1988).

229. Id. § 2604(a)-(b).

230. Office of Technology Assessment, The Information Content of Premanufacture Notices 6-7, 49-54 (1983). On the other hand, the most data existed for the highest exposure chemicals. Id. at 6-7, 76-77.

231. 15 U.S.C. $\S 2607$ (c) (1988). Similar provisions may be found at 7 U.S.C. § 136f(a) (1988) (FIFRA); 42 U.S.C. § 6924(a)(1) (1988) (RCRA); and id. § 9603(d) (CERCLA). 
existence of any health or safety study of such chemicals regardless of who performed the study, ${ }^{232}$ and to report information that "reasonably supports the conclusion that such substance or mixture presents a substantial risk of injury."2s3

Data compilations and information gathering go a long way toward remedying the lost book problem. They are relatively cheap and can be tailored for relevance and coverage. The importance of locating and assembling previously inaccessible information cannot be overstated; in some cases it is tantamount to creating new information. But data compilations do not, in fact, create new information. The toxic substances data gap is not just the result of a poorly organized library. Most of the needed data are simply nonexistent, and many existing data are of poor or uncertain quality. It is necessary, therefore, to generate new data.

2. Recordkeeping, Monitoring, and Inspection. - EPA is authorized by all of the principal toxics statutes to collect and create data by requiring recordkeeping, monitoring, and inspections. ${ }^{234}$ An industrial operation of any size keeps voluminous records on production, raw materials, waste products, quality assurance, employee health, and legal claims against it, all of which are subject to EPA requirements to maintain records for inspection. Recordkeeping requirements create new information in the sense that the data EPA obtains would not otherwise have existed, or at least would not have been assembled in a coherent way. By implementing this authority with standardized formats, EPA generates data that can be used for many purposes, concerning virtually any chemical under virtually any regulatory program. ${ }^{235}$

General recordkeeping requirements, however, are almost inevitably overbroad. To catch all of the information in which the agency has a genuine interest, it must cast a wide net. Collecting, sorting, and analyzing irrelevant information wastes money that usefully could be spent elsewhere. Obviously, EPA cannot always know in advance what will

232. See 15 U.S.C. $\$ 2607$ (d) (1988). Similar provisions may be found at 7 U.S.C. $\S 136 \mathrm{~d}(\mathrm{a})(2), 40$ C.F.R. $\$ \S 153.66-153.78$ (1989) (regulations under F1FRA); and 42 U.S.C. $\$ 6921(\mathrm{~b})(3)(\mathrm{B})(\mathrm{i})(\mathrm{Il})(\mathrm{RCRA})$.

233. 15 U.S.C. $\$ 2607$ (e). A similar provision may be found at 7 U.S.C. $\S 136 \mathrm{~d}(\mathrm{a})(2)$ (FIFRA); see also 40 C.F.R. $\$ \S 153.70-153.77$ (1989) (EPA regulations implementing $\S 136(\mathrm{a})(2))$.

234. For books and records, see 7 U.S.C. $\$ 136$ f (FIFRA); 15 U.S.C. $\S 2607$ (a) (predictably elaborate and complete TSCA provisions); for monitoring, see 7 U.S.C. $\$ 136 \mathrm{r}$ (F1FRA); 15 U.S.C. $§ 2609$ (d) (TSCA); 42 U.S.C. $\$ 6934$ (RCRA); see also E.I. duPont de Nemours \& Co. v. Daggett, 610 F. Supp. 260, 264 (W.D.N.Y. 1985) (ordering monitoring); 33 U.S.C. $\$ 1318$ (a) (1988) (authorizing monitoring under the Federal Water Pollution Control Act); for inspection and access, see 7 U.S.C. $\S 136 g$ (FIFRA); 15 U.S.C. § 2610 (TSCA); 42 U.S.C. § 6927 (RCRA); id. § 9604(e) (CERCLA response authorities).

235. Hayes, Sleeping Giant, supra note 9, at 4-5; see, e.g., EPA, Comprehensive Assessment Information Rule, 54 Fed. Reg. 30,211 (1989) (request for additional comments on final rule to be codified at 40 C.F.R. pt. 704, July 19, 1989); Comprehensive Assessment Information Rule, 40 C.F.R. \$§ 704.200-.219 (1989). 
and will not be of concern, so it often has used its recordkeeping powers cautiously and narrowly to avoid becoming overwhelmed by information and imposing undue expense on industry. ${ }^{236}$

Monitoring and inspection, other than random administrative inspections as part of routine enforcement, avoid the relevance problem because the agency does not undertake them without some prior determination of need. Monitoring and inspection, like recordkeeping, are invaluable for research on exposure and epidemiological issues, and critical for enforcement, ${ }^{237}$ though their utility elsewhere in the risk assessment process is limited. However, they can be used only sparingly because they are extremely expensive. ${ }^{238}$ The federal government spends about $\$ 500$ million annually on environmental monitoring, but much more would have to be done to fill gaps and to coordinate the data. ${ }^{239}$

Registries are a different form of monitoring. ${ }^{240}$ As its name indicates, one of ATSDR's primary duties is to establish registries of persons exposed to toxic substances and of the health effects of toxic substances. ${ }^{241}$ Congress's goal was to "build a comprehensive body of data that will define the threat that toxic chemicals pose to human health."242 Registries not only permit the identification of individuals who may be at risk for toxic illness, but also can reveal epidemiological patterns that would not be apparent from isolated pieces of data. ${ }^{243}$

236. For example, EPA has imposed detailed recordkeeping requirements under TSCA on only a handful of chemicals. See 40 C.F.R. pt. 704 (1989). To sort information, it developed a "flagging" system under FIFRA for new registrations and material submitted in response to data call-ins. Id. $\$ 158.34$. See infra text accompanying notes 282-287.

237. EPA, Toxic Substances Control Act (TSCA): Report to Congress for Fiscal Year 1984, at 18 (1985); accord Callahan, Dioxin Pathways: Judging Risk to People, EPA J., May/June 1989, at 29, 30.

238. See McGarity, supra note 28, at 210.

239. Messer, Keeping a Closer Watch on Ecological Risks, EPA J., May/June 1989, at 34,35 . Messer estimates that over $\$ 1$ billion is spent by states and private organizations. Id. Even so, the Clean Air Act had to create an "unclassifiable" category for air quality control regions whose attainment status cannot be determined due to lack of data that could be obtained by monitoring and inspection. 42 U.S.C. $\S 7407$ (d)(1)(D) (1988). The Clean Air Act 1990 Amendments do the same. Pub. L. No. 101-549 $\S 101$ (a), 104 Stat. 2399, 2399-400 (1990) (to be codified at 42 U.S.C. $\S 7407(\mathrm{~d})(\mathrm{l})(\mathrm{A})(\mathrm{iii}))$.

240. "A registry is defined as a system for collecting and maintaining in a structured record, information on specific persons from a defined population." Public Health Service, Privacy Act of 1974; New System of Records, 53 Fed. Reg. 30,720, 30,720 n.2 (1988) (proposed Aug. 15, 1988).

241. See 42 U.S.C. $\$ 9604$ (i)(1) (1988). In addition, if study of a particular site reveals the need, ATSDR is authorized to conduct epidemiological studies, establish a registry of exposed persons, and conduct a health surveillance program. 1d. $\S 9604$ (i)(7)-(9). For an overview, see H.R. Rep. No. 253, supra note 195, pt. 5, at 30-36, reprinted in 1986 U.S. Code Cong. \& Admin. News at 3153-59.

242. S. Rep. No. 11, supra note 187, at 28.

243. See Amending and Extending the Comprehensive Environmental Response, 
However, establishing useful registries consumes sizable resources because it requires both monitoring and analysis. Despite its name, ATSDR is only beginning work in this area. ${ }^{244}$

3. Government Research. - Original research is a major component of EPA's activities. Congress appropriates large sums of money to the programs established under EPA's jurisdiction, and EPA employs hundreds of research personnel and contracts out substantial amounts of research work. ${ }^{245}$ All of the toxics statutes provide for governmentfunded research at government facilities, universities, or independent laboratories. ${ }^{246}$

Government research may be subdivided into specific and general research. The government has several programs that conduct toxicological testing and risk assessment for specific substances. ${ }^{247}$ Research sponsored by the government ought to avoid the bias that can affect privately produced data, ${ }^{248}$ and it can be tailored to provide direct sup-

Compensation, and Liability Act of 1980 (Superfund): Hearings Before the Senate Comm. on Env't and Public Works, 98th Cong., 2d Sess. 674 (1984) [hereinafter Amending and Extending CERCLA Hearings] (statement of Vernon N. Houk); Hazardous Waste Contamination of Water Resources (Compensation of Victims Exposed to Hazardous Wastes): Hearings Before the Subcomm. on Investigations and Oversight of the House Comm. on Public Works and Transportation, 98th Cong., 1st Sess. 1260-61 (1983) (statement of Vernon N. Houk on long-term health effects).

244. Johnson, Implementation, supra note 220, at 10,279-80; Siegel, supra note 175 , at 10,017 .

245. President Bush's 1991 Budget proposal allocated $\$ 449.6$ million to EPA research and development. EPA, Summary of the 1991 Budget 55 (1990). In 1983 private industry spent $\$ 44.3$ billion in research and development and government spent $\$ 39.6$ billion. J. Petulla, Environmental Protection in the United States 176-77 (1987).

246. See 7 U.S.C. $\S 136$ r (1988) (FIFRA); 15 U.S.C. $\S \S 2609,2626$ (1988) (TSCA); 42 U.S.C. $\$ \S 6981-6987$ (1988) (RCRA); id. \$§ 9651, 9660 (CERCLA). Recognizing the inadequate data base for Superfund, Congress in enacting SARA turned to new governmental research, grants, and contracts with universities to fill the need. See H.R. Rep. No. 253, supra note 195, pt. 1, at 87-88, reprinted in 1986 U.S. Code Cong. \& Admin. News at 2869-70; id., pt. 5, at 28, 30, reprinted in 1986 U.S. Code Cong. \& Admin. News at 315I, 3153.

For an overview of EPA's research operations, see EPA, FY 1990: EPA Research Program Guide (1989); EPA, Long-Range Research Agenda for the Period 1988-92 (1987); 2 National Research Council/National Academy of Sciences, Decision Making in the Environmental Protection Agency 58-66 (1977) [hereinafter Decision Making in the EPA].

247. Many are centralized in the National Toxicology Program (NTP), which is comprised of several research agencies of the Department of Health and Human Services. See U.S. Dep't of Health and Human Services, Doc. No. NTP-89-167, National Toxicology Program: Fiscal Year 1989 Annual Plan 1 (1989).

248. See infra notes 271-276 and accompanying text.

However, in recent bills to promote EPA to the status of a Cabinet-level department, congressional committees have proposed the establishment within EPA of an independent Bureau of Environmental Statistics. Several persons in Congress were concerned-based perhaps on the recent global warming and acid rain debates in which the Reagan and Bush Administrations based their wait-and-see positions on a supposed lack of reliable data, see supra note 108-that environmental statistics not be politically 
port for program decision making. However, given the expense of this research, the number of substances that can be investigated is extremely limited. ${ }^{249}$ There will never be enough money in a federal or state budget to fill the existing data gaps on a chemical-by-chemical basis. ${ }^{250}$

Consequently, general research, such as the development of research methodologies and standards, is a more cost-effective alternative. ${ }^{251}$ EPA's efforts are better spent, for instance, improving risk assessment methodology than performing a risk assessment for a given chemical or Superfund site. ${ }^{252}$ Similarly, uniform methods for the collection of information used in risk assessment and quality control can be accomplished effectively only as centralized, governmental activities. ${ }^{253}$ The more general the research, the more it is like a public

influenced, either by EPA or by other parts of the Administration. See S. 2006, supra note 215; H.R. 3847, supra note 215; Senate Committee Adopts Legislation to Establish EPA as Cabinet-Level Agency, supra note 215, at 1845.

249. There may be two exceptions. First, ATSDR site-specific health assessments may not be terribly expensive because they involve mainly risk characterization, the final and least information-intensive step of quantitative risk assessment. See supra text accompanying notes 91, 144. Of course, these assessments generate no new data. Second, Professor Lyndon has proposed a "superstudy" program, which would create new data, financed (like Superfund) by a tax on chemical producers. The attraction of such a program is not only its affordability, but its cost-effectiveness-assuming the need for such testing at some point, it is more sensible to do it early. Lyndon, Information Economics, supra note 6 , at $1836-41$.

250. Before reimbursement provisions were added to the ATSDR sections of SARA, it was estimated that its research would cost the Superfund $\$ 40$ million in Fiscal Year 1990. H.R. Rep. No. 253, supra note 195, pt. 1, at 90 , reprinted in 1986 U.S. Code Cong. \& Admin. News at 2872 . SARA authorizes $\$ 60$ million per year by fiscal year 1990 for ATSDR, 42 U.S.C. $\$ 9611(\mathrm{~m})(1988)$, based on astonishingly low estimates of the cost of Superfund site studies, e.g., as low as $\$ 100,000$ for a full-scale epidemiological study. See S. Rep. No. 11, supra note 187, at 31.

251. Shapiro, Divorcing Profit Motivation from New Drug Research: A Consideration of Proposals to Provide the FDA with Reliable Test Data, 1978 Duke L.J. 155, 170-75.

252. J. Petulla, supra note 245 , at 179-81. EPA has recently launched a program of general Research to Improve Health Risk Assessments to establish a coherent program for reducing generic uncertainties in the risk assessment process. See generally RIHRA, supra note 136 (describing Office of Research \& Development research program to improve health risk assessment).

Other basic research appropriate for government funding includes biomedical processes, environmental transport models, dose-response models, inter-media effects, technical training, epidemiological research, measurement and detection techniques, and anticipating future problems and research needs. See Council on Environmental Quality, supra note 142, at 98-128 (1990); RIHRA, supra note 136, at 12-14. Studies of specific chemicals that are ubiquitous in the environment, that are present as constituents or impurities in many substances (e.g., dioxins), or whose toxic properties can reliably be imputed to others of similar structure or activity also may be appropriate for governmental efforts.

253. See Amending and Extending CERCLA Hearings, supra note 243, at 663-65 (statement of James O. Mason, ATSDR director). EPA has spent a lot of time setting testing guidelines and protocols, including TSCA generic test guidelines, see 40 C.F.R. 
good, and the more appropriate-indeed, essential-it is that the government supply it. In areas like exposure or dose-response, in which models must be used, general research contributes directly to the information needed by the regulatory process. By and large, however, such research facilitates the production of data rather than filling the data gap itself.

4. Licensing. - Placement of the burden of proof affects both substantive regulatory policy and information development. When the burden is on EPA to demonstrate risk, EPA has an incentive to develop toxicity information, but the regulated entity has a strong disincentive to develop it, especially if it seems likely that further information will prove troublesome. Conversely, if as a general rule manufacturers can develop toxicology information more cheaply than EPA, or if the cost is more efficiently or equitably borue by them and their customers, then it makes sense to assign the burden of proof to the manufacturer. ${ }^{254}$ In regulatory systems, shifting the burden of proof from the government to industry is typically accomplished by enacting a licensing or screening system. In the case of toxic substances, chemical producers would have to demonstrate the safety of their products before these products could be introduced into commerce. Licensing, therefore, not only provides an incentive to the development of new information; it also shifts the cost of development away from the government to a group that in theory has the capacity to absorb and spread the cost.

Of the toxics statutes, only FIFRA has a true licensing scheme. Before pesticides can be sold, they must be registered and EPA must determine that they do not present an unreasonable risk. ${ }^{255}$ The regis-

pts. 796-99 (1990); requirements in $\$ 4$ rules, see 15 U.S.C. $\$ 2603$ (a),(b) (1988); and F1FRA Good Laboratory Practice Standards, see 40 C.F.R. pt. 160 (1989). Its testing programs have established guidelines for conducting required experiments. See, e.g., EPA, Mouse Visible Specific Locus Test Requirement; Final Amendment in Test Rules, 55 Fed. Reg. 12,639 (1990) (to be codified at 40 C.F.R. pts. 798-99) (TSCA $\S 4$ test rule for detecting heritable gene mutations); EPA, Commercial Hexane; Proposed Pharmacokinetics Test Requirements and Revision of Proposed Test Guideline, 53 Fed. Reg. 45,289 (1988) (to be codified at 40 C.F.R. pts. 795, 799) (proposed Nov. 9, 1988) (TSCA § 4(a) test rule for commercial hexane); EPA, Federal Insecticide, Fungicide, and Rodenticide Act Amendments of 1988, Pub. L. No. 100-532, 102 Stat. 2654 (1988). See generally Whitney, supra note 139 , at 120-42 (discussing testing procedures, quality assurance/quality control programs, and laboratory accreditation).

254. Cf. Gelpe \& Tarlock, supra note 20, at 415-25 (arguing that burden of proof has little meaning where information is scarce and that burdens therefore should be allocated to minimize cost of gathering and developing risk information).

255. 7 U.S.C. $\S 136 \mathrm{a}(\mathrm{a})$, (c)(5) (1988). The TSCA PMN process is an ingenious compromise between ex ante and ex post regulation: the manufacturer must obtain a kind of approval (actually, absence of disapproval) for production of the chemical, yet licensing delays are minimized. This procedure at most delays introduction of a chemical into commerce; any further restrictions must be justified by EPA. 15 U.S.C. $\S 2604(f)$, 2618(c)(1)(A) (1988). RCRA has a permitting system for hazardous waste facilities, but it relates primarily to the performance characteristics of the facilities as opposed to their contents. 42 U.S.C. § 6925 (1988). 
trant has the initial and continuing burden of demonstrating safety, though EPA has an initial burden of production in a cancellation proceeding and must ultimately be able to support its conclusions by substantial evidence. ${ }^{256}$ By placing the burden on the registrant, EPA is able to obtain whatever information it deems necessary to assess whether the chemical poses an unreasonable risk through the simple expedient of specifying data requirements for registration. 257 EPA needs only the most general justification for these requirements, given the breadth of factors relevant to the unreasonable risk determination. Furthermore, the data requirements apply to all pesticides, eliminating the need to demand data on a chemical-by-chemical basis. ${ }^{258}$ This technique obviously brings the full profit motive to bear in developing adequate data in an expeditious manner. It is hardly coincidental that of the chemicals surveyed in the Toxicity Testing report, the two groups about which the most is known are the two-pesticides and ethical drugs ${ }^{259}$ - that require premarket licensing.

Californians have enacted a far more ambitious screening statute with the Safe Drinking Water and Toxic Enforcement Act of 1986 (Proposition 65). ${ }^{260}$ Users and producers of toxic substances must warn people of all exposures to a lengthy list of chemicals "known to the state to cause cancer or reproductive toxicity," and are prohibited from making any discharges of the chemicals into drinking water unless the user or producer can "clearly show[] by scientifically valid testing according to generally accepted principles" that "the exposure poses no significant risk." 261 In the case of Proposition 65, screening has provided a strong incentive to the government to take action. The state arguably is authorized to establish specific threshold levels that would meet the "no significant risk" test,262 and it sought to do so to afford some degree of certainty to businesses affected by Proposition 65. ${ }^{263}$

256. See National Coalition Against the Misuse of Pesticides v. EPA, 867 F.2d 636, 642 (D.C. Cir. 1989); Environmental Defense Fund, Inc. v. EPA, 548 F.2d 998, 1005 (D.C. Cir. 1976) (licensing of heptachlor and chlordane), cert. denied, 431 U.S. 925 (1977); Environmental Defense Fund, Inc. v. EPA, 510 F.2d 1292, 1297-98 (D.C. Cir. 1975) (aldrin and dieldrin); Environmental Defense Fund, Inc. v. EPA, 465 F.2d 528, 537 (D.C. Cir. 1972) (aldrin and dieldrin).

257. EPA has promulgated extensive data requirements regulations that read like a checklist of risk assessment inputs. See 40 C.F.R. pt. 158 (1990).

258. 7 U.S.C. $\$ 136$ (a) (1988).

259. See Toxicity Testing, supra note 6 , at 82.

260. Cal. Health \& Safety Code $\$ \S 25249.5-25249.13$ (West 1991).

261. Id. at $\S 25249.8(\mathrm{a}), .8(\mathrm{~b}), .10$ (c). For a detailed analysis of this statutory language in relation to warnings, see Stevens, Regulating Toxics at the State Level: Proposition 65's Warning Requirement, 9 Stan. Envtl. L.J. 84, 89-123 (1990).

262. See Uram, Proposition 65: No Safe Harbor?, Nat. Resources \& Env't, Winter 1990 , at 16,17 .

263. See Kizer, Warriner \& Book, Sound Science in the Implementation of Public Policy: A Case Report on California's Proposition 65, 260 J. A.M.A. 951, 952-53 (1988); Roe, Barking up the Right Tree: Recent Progress in Focusing the Toxics lssue, 13 
In the year after Proposition 65 went into effect, the California government set twice as many specific discharge levels as EPA did in twelve years under TSCA. ${ }^{264}$ Although such quick results must have been based almost exclusively on existing information, the potential for generating new data in the future is clear, depending in part on the rigor with which the state demands proof of safety in its own and industry's risk assessments. ${ }^{265}$

Licensing is not without serious drawbacks. First, it is a very cumbersome-hence expensive-way to regulate because each individual product or activity must be evaluated. As a result, it should be used only when the factual differences among products or activities are sufficiently great to justify individual consideration. ${ }^{266}$ This limitation leads to a second problem-timing. The safest time to evaluate a risk is before thousands are exposed to it. But extensive premarket investigation inevitably causes serious delays in the introduction of useful products, as there is no reliable way to determine accurately $e x$ ante which products are hazardous and require further investigation. 267 Screening may have the opposite and equally undesirable effect on old products: the difficulty of individually deciding to remove them from the market permits continued exposure to unsafe products. ${ }^{268}$ Furthermore, licensing often depends on the presentation of only existing information, much of which falls well short of current scientific standards and practices. ${ }^{269}$ Data quality can be improved by establishing standards for the acceptability of data submitted to the agency, as EPA has done, ${ }^{270}$ but this

Colum. J. Envtl. L. 275, 277-78 (1988). John Van De Kamp, California Attorney General and proponent of Proposition 65, stated that the statute "creates a major incentive ... to establish scientifically determined 'safe levels' through regulation." Van De Kamp, A Toxics Law with Teeth, L.A. Times, Oct. 31, 1986, pt. 2, at 5, col. 1.

264. Roe, supra note 263, at 279. The 1990 Clean Air Act amendments include a similar "hammer" for air toxics regulation: if EPA does not promulgate emissions levels by the statutory deadline, emitters must either cease emissions within 18 months or obtain a stringent permit. Clean Air Act Amendments of 1990, Pub. L. No. 101-549, $\S 301 j(2), 104$ Stat. 2399, 2551 (1990) (to be codified at 42 U.S.C. $\S 7412(j)(2)$ ).

265. The initiative uses numerical risk standards, see Cal. Health \& Safety Code $\S 25249.10$ (c) (West 1991), and the regulations adopt quantitative risk assessment, see Cal. Admin. Code tit 26, §§ 22-12701(b)(1), 12703 (1990).

266. See generally S. Breyer, supra note 22, at 133-55 (describing appropriate use of screening techniques for food additives).

267. See Merrill, supra note 3, at 481 ("Performing this kind of analysis [animal data] can slow, perhaps paralyze, regulation."). These delays also may have adverse effects on innovation by increasing the cost and uncertainty of new product lines. See Davies, The Effects of Federal Regulation on Chemical Industry Innovation, Law \& Contemp. Probs., Summer 1983, at 41, 51-52. But see Ashford \& Heaton, Regulation and Technological Innovation in the Chemical Industry, Law \& Contemp. Probs., Summer 1983, at 109, 140-41 (criticizing arguments that regulation stifles innovation).

268. S. Breyer, supra note 22 , at 135 .

269. Toxicity Testing, supra note 6 , at 85 .

270. See 40 C.F.R. $\$ 158.70$ (1989) (requiring testing to conform to Pesticide Assessment Guidelines, which are separately published by EPA). 
approach increases approval delays.

Another quality issue is the source of the data, especially in the uncertain science of long-latency toxic illnesses in which inference and interpretation are always open to debate. ${ }^{271}$ The inevitably conflicting interests between EPA and the industries it regulates invite the withholding or slanting of data submissions. The conflict rarely results in outright concealment, falsification, or deliberate misstatement of results (though this unfortunately is not unknown).272 Rather, every stage of the investigation process, from experimental design to execution to interpretation of results, is subject to judgment and inferenceand to bias. ${ }^{273} \mathrm{~A}$ screening or approval system may magnify the bias problem by casting EPA and industry in more obviously adversarial roles. ${ }^{274}$ A National Academy of Sciences study of EPA decision making warned about dependence on regulated industries for data and analysis and suggested a number of remedial measures, including reduced use of consulting firms that also work for industry, peer review, review by other agencies, stringent guidelines and protocols, certification of laboratories, and a strong in-house research capacity. ${ }^{275}$ Echoing a 1989 Office of Technology Assessment recommendation, EPA recently announced its intention to bring CERCLA risk assessment in-

271. See Federal lnsecticide, Fungicide, and Rodenticide Reform Act and Pesticide Import and Export Act of 1983: Hearings on H.R. 3818 Before the Suhcomm. on Department Operations, Research, and Foreign Agriculture of the House Comm. on Agriculture, 98th Cong., 1st Sess. 343, 347 (1983) (testimony of EPA Administrator Ruckelshaus acknowledging that government reports are often prepared from industry reports); McGarity, supra note 20, at 743-47.

272. Cf. Shapiro, supra note 251 , at $166-68$ (describing poor procedures and deliberate data distortion in industry-generated research provided to FDA).

273. Bias in this sense does not necessarily mean deliberate inaccuracy, but only a pervasive inclination to see data come out favorably. 1d. at 156, 161-68; see also Marshall, The Murky World of Toxicity Testing, 220 Science 1130, 1132 (1983) (criticizing government use of laboratories that also work with industry).

274. Spector, Regnlation of Pesticides by the Environmental Protection Agency, 5 Ecology L.Q. 233, 253-55 (1976) (asserting that, since manufacturer is clearly cast as adversary in later stages of pesticide cancellation proceeding, EPA's use of manufacturer data to make ultimate decisions regarding unreasonable risk should be suspect).

In the FIFRA data call-in process, 7 U.S.C. § 136a(c)(2)(B) (1988) discussed infra notes 278-290 and accompanying text, which often precedes actual regulatory action, the information that must be supplied by industry is called "defensive data," H.R. Rep. No. 695, 99th Cong., 2d Sess. 71 (1986), a choice of words suggesting an adversarial posture. Cf. Davies, supra note 267, at 49-50 (regulation encourages " 'defensive" " research and development instead of development of major improvements or new products).

275. 2 Decision Making in the EPA, supra note 246, at 50-58. Congress has proposed to forbid EPA's use of private contractors for functions that are "inherent to government" and to require public notice of any other contract that uses companies that perform like services for private industry. See S. 2006, supra note 215; H.R. 3847, supra note 215; Senate Committee Adopts Legislation to Establish EPA as Cabinet-Level Agency, supra note 215, at 1845 . 
house because it found private efforts less protective. ${ }^{276}$ Unfortunately, this plan essentially mandates specific government research, which has sharp budgetary limits.

Finally, licensing used alone has limited coverage in two senses. First, the premarket phase of product development is the time when the least information is known about a chemical's long-term effects. Without indications of chronic toxicity, it is hard to justify lengthy, expensive bioassays. Second, a licensing scheme intercepts only new or prospective risks. Since older chemicals are likely to be less well-tested relative to more recently licensed chemicals, the lack of data on existing chemicals constitutes a major gap in an information generation system. This problem can be resolved by a retroactive licensing arrangement like FIFRA's reregistration process. ${ }^{277}$ However, re registration presents EPA with a huge backlog of chemicals to be licensed, which EPA must work through slowly or approve with little investigation; that is, it can either accept delay or risk poor decisions.

In sum, neither the unregulated market, nor tort law, nor standard statutory information acquisition techniques are likely to fill the toxic substances data gap. Compilations of existing data create new information only in the sense of access and aggregation; government research is confined by expense to a small direct role in generating new information about toxic substances; recordkeeping lacks flexibility and precision, while monitoring and inspections provide limited types of new information at considerable expense; and licensing, while a powerful technique, tends to be unselective, to be narrow in coverage, and to occasion serious delays.

\section{Requirements to Test}

\section{A. Two Models}

Both FIFRA and TSCA contain an information technique that differs from any of the foregoing methods. They permit EPA to require the manufacturer or processor of an existing chemical to undertake testing at its own expense covering the entire range of information relevant to the unreasonable risk determination. By imposing testing obligations for existing chemicals, FIFRA and TSCA directly tackle the most pressing problem for a regulatory regime based on unreasonable risk and quantitative risk assessment. The requirement to test has the potential to begin to fill the toxic information gap, especially when combined with the information-gathering techniques described above.

276. EPA Will Do All Risk Assessments, Says Private Cleanups Are Protective, 21 Env't Rep. (BNA) 414, 414-15 (June 29, 1990).

277. As part of its licensing plan, FIFRA reaches back to catch older pesticides that may have been originally registered on outdated information or techniques. 7 U.S.C. $\S 136 a-I$ (1988). In addition, registration lasts only five years, at which time reregistration is required. Id. $\S 136 \mathrm{~d}(\mathrm{a})(\mathrm{I})$. 
1. FIFRA Data Call-Ins. - Recognizing that licensing fails to generate any information for existing chemicals or post-license information for new ones, FIFRA established a five-year registration period after which reconsideration is necessary. This provision has not generated large amounts of data, however, because EPA has never used the fiveyear period aggressively for this purpose. ${ }^{278}$ Indeed, EPA has lacked sufficient resources to do much more than keep current on new registrations and cancellations. ${ }^{279}$ In addition, FIFRA provides for two kinds of interim action: cancellation of the registration if the pesticide no longer meets the unreasonable risk standard, and reregistration of older pesticides. ${ }^{280}$ Cancellation, however, is a burdensome formal adjudication, ${ }^{281}$ and it presupposes sufficient information to decide whether to initiate the adjudication; reregistration has proceeded at an extremely slow pace.

In 1978 Congress added FIFRA's requirement to test, known as a "data call-in," to clarify EPA's power to seek information to facilitate review of previously approved pesticides. ${ }^{282}$ The data call-in is a logical extension of a licensing statute that places the burden of proving safety on the registrant. It allows EPA to demand additional data concerning any pesticide whenever the agency "determines that additional data are required" to support the registration. ${ }^{283}$ The data call-in provision gives EPA the authority to require the creation of new information, ${ }^{284}$ and it empowers EPA to seek any information relevant to the broad range of considerations relevant to determining unreasonable risk under FIFRA. ${ }^{285}$ The provision is potentially draconian in applica-

278. Ferguson \& Gray, 1988 FIFRA Amendments: A Major Step in Pesticide Regulation, 19 Envtl. L. Rep. (Envtl. L. Inst.) 10,070, 10,071-76 \& n. 17 (1989). One of the goals of the 1988 FIFRA amendments was to provide the machinery and resources to speed this process.

279. H.R. Rep. No. 939, 100th Cong., 2d Sess. 29, reprinted in 1988 U.S. Code Cong. \& Admin. News 3474, 3478.

280. 7 U.S.C. § 136a-1 (1988) (reregistration); id. § 136d (cancellation and suspension).

281. See id. § 136d(b), (d) (providing for public hearings and referrals to Secretary of Agriculture, FlFRA Scientific Advisory Panel, and National Academy of Sciences). EPA has attempted to streamline the process through its Special Review process, 40 C.F.R. pt. 154 (1989).

282. 7 U.S.C. $\S 136 \mathrm{a}(\mathrm{c})(2)(B)(\mathrm{i})$ (1988); H.R. Rep. No. 663, 95th Cong., 1st Sess. 25 (1977). For an overview of FIFRA's data requirements, see Perlis, The Push for Data on Existing Pesticides, Nat. Resources \& Env't, Winter 1990, at 6, 6.

283. 7 U.S.C. $\$ 136 a$ (c)(2)(B)(i).

284. See Chemical Specialties Mfrs. Ass'n v. EPA, 484 F. Supp. 513, 516 (D.D.C. 1980) (contrasting data call-in with reporting requirement of 7 U.S.C. $\$ 136 d(a)(2)$ ).

285. See 7 U.S.C. $\$ 136$ (bb) ("any unreasonable risk to man or the environment, taking into account the economic, social, and environmental costs and benefits"); see also EPA, Tributyltin Antifoulants; Notice of Intent to Cancel; Denial of Applications for Registration; Partial Conclusion of Special Review, 53 Fed. Reg. 39,022, 39,037 (1988) (proposed Oct. 4, 1988) (requesting benefits information).

EPA usually relies on its registration guidelines (40 C.F.R. $\S 158(1989)$ ) to estab- 
tion because FlFRA does not limit the occasions for using data call-ins, and EPA has developed neither formal nor informal guidelines for their use. ${ }^{286}$ Moreover, registrants have no real choice but to comply because they have no right to challenge the request-the only question on judicial review is whether the registrant did in fact comply with the callin, not whether it should comply. ${ }^{287}$

Data call-ins have not been used to their full potential to generate large amounts of information. Consistent with their role in support of post-licensing review of pesticides, they have rarely been used outside of ongoing reregistration and cancellation proceedings. ${ }^{288}$ And because they can impose an enormous financial burden on affected registrants, EPA considers the extent of use and human exposure, as well as the cost impact of data generation, in establishing data call-ins. EPA adopts, in effect, a form of quantitative risk assessment. ${ }^{289} \mathrm{ln}$ addition, some legislative history suggests that the data call-in should be used only in extremely unusual circumstances. ${ }^{290}$ As a result, EPA has not used the data call-in as a general source of toxic substances information.

lish data needs, see EPA, Pesticide Registration Procedures; Pesticide Data Requirements, 53 Fed. Reg. 15,952 (1988) (to be codified at 40 C.F.R. pts. 152, 153, 156, 158, 162), though it reserves the right to ask for additional information, see 40 C.F.R. $\S 158.75$ (a) (1989).

286. The regulations under FIFRA are as opaque as the statute. See 40 C.F.R. $\$ 153.70$ (b)(3) (1989) (discussing basis for policy regarding incomplete toxicological studies). Data call-in notices themselves have made a few general statements about the goals of the program and the information it seeks, but there is little general guidance. See, e.g., EPA, Data Call-In Initiation of Pilot Program, 45 Fed. Reg. 66,736, 66,736-37 (1980) (to be codified at 40 C.F.R. pt. 162) (proposal Oct. 7, 1980) (stating general goal of obtaining chronic effects data and identifying data gaps for reassessment and reregistration); EPA, Pesticide Registration and Classification Procedures, 49 Fed. Reg. 37,916 (1984) (to be codified at 40 C.F.R. pts. 152, 157, 158, 162) (proposed Sept. 26, 1984) (program intended to fill data gaps).

287. See 7 U.S.C. $\S 136 a(c)(2)(B)$ (iv) (1988).

288. See Federal Insecticide, Fungicide, and Rodenticide Act; and Pesticide Import and Export Act of 1985, Part I: Hearings on H.R. 1416, H.R. 1910, and H.R. 2482 Before the Subcomm. on Department Operations, Research, and Foreign Agriculture of the House Comm. on Agriculture, 99th Cong., 1st Sess. 8-9, 45-47 (1985) [hereinafter 1985 House FIFRA Hearings] (statement of John A. Moore, Assistant Administrator, Office of Pesticides and Toxic Substances (OPTS), EPA); Perlis, supra note 282, at 8-9. The need for data call-ins in connection with re registration has been superseded by a new (1988) section which provides for acquisition of information. 7 U.S.C. § 136a-1 (1988). However, the new section does not limit the use of data call-ins for reregistration or any other purpose. H.R. Rep. No. 939, supra note 279, at 30, reprinted in 1988 U.S. Code Cong. \& Admin. News at 3479.

289. See, e.g., EPA, Toxicology Data Call-In for Antimicrobial Pesticides, 52 Fed. Reg. 595, 595 (1987); EPA, Pesticide Registration and Classification Procedures, supra note 286 , at $37,921-22$.

290. H.R. Rep. No. 253, supra note 195, pt. 1, at 88, reprinted in 1986 U.S. Code Cong. \& Admin. News at 2870 (ATSDR); H.R. Rep. No. 511, 92d Cong., 1st Sess. 20 (1971) (regarding 1972 predecessor of data call-in). 
2. TSCA Test Rules. - Like the data call-in, section 4 of TSCA permits EPA to promulgate test rules to require an actual or intended chemical manufacturer or processor to generate new data by conducting testing covering the full range of health and environmental effects relevant to TSCA's determination of unreasonable risk. ${ }^{291}$ It was anticipated that section 4 information would be used principally in deciding whether to impose substantive restrictions under section 6 of the Act. ${ }^{292}$ However, as with the data call-in, the language of section 4 is not so narrowly drawn. The coverage of the TSCA test rule provision is as broad as the coverage of the statute itself, which extends to virtually all chemical substances. ${ }^{293}$

In contrast to data call-ins, however, TSCA test rules are rules in the Administrative Procedure Act sense and subject to elaborate procedures for development, promulgation, and judicial review. The section 4 process begins with the recommendation, based on standard risk assessment criteria, by the Inter-agency Testing Committee (ITC) of chemicals for priority testing. EPA reviews the recommendations in light of statutory criteria, subjects tentative decisions to public comment, and decides whether or not to initiate a rulemaking. ${ }^{294}$ The proposed rule is subject to hybrid rulemaking procedures, including oral argument, transcripts, and findings. ${ }^{295}$

TSCA differs from FIFRA in another respect as well. TSCA requires EPA to justify its decision to impose test rules by making three specified findings supported by substantial evidence on the rulemaking record. ${ }^{296}$ The first finding is bifurcated: EPA must show either that the chemical "may present an unreasonable risk of injury to health or the environment," or that the chemical is manufactured in "substantial quantities" to which "siguificant or substantial human exposure" is likely. ${ }^{297}$ In other words, if either the risk equation as a whole (toxicity $\mathrm{x}$ exposure) or the exposure factor alone appears to be high, then testing is required. This initial finding requires a case-by-case determination for each rule, and it has been the focus of most section 4 litigation. ${ }^{298}$

291. See 15 U.S.C. $\S 2603(a),(b)(2)$ (1988).

292. See Chemical Mfrs. Ass'n v. EPA (CMA I), 859 F.2d 977, 979 (D.C. Cir. 1988); see also 15 U.S.C. $\$ 2603(f)(1)(1988)$ (permitting restrictive action based on indications from test data).

293. See 15 U.S.C. $\$ 2602(2)(B)$ (defining "chemical substance" to exclude pesticides, tobacco, nuclear material, and foods, drugs, and cosmetics).

294. See id. § 2603(e).

A manufacturer may negotiate a testing program with EPA, but such an agreement must be enforceable through an officially promulgated, mandatory rule. See Natural Resources Defense Council, Inc. v. EPA, 595 F. Supp. 1255, 1260-62 (S.D.N.Y. 1984); 40 C.F.R. $\$ 799$ (1990). See generally Hayes, New Life, supra note 9, at 67-68 (describing negotiated test rule history and procedures).

295. See 15 U.S.C. $\$ 2603$ (b)(5) (1988).

296. See id. $\$ 2618(a)(3)$ (rulemaking record), (c)(1)(B)(i) (standard of review).

297. 15 U.S.C. $\$ 2603(\mathrm{a})(\mathrm{I})(\mathrm{A})(\mathrm{i}),(\mathrm{a})(\mathrm{l})(\mathrm{B})(\mathrm{i})(\mathrm{II})$.

298. See Chemical Mfrs. Ass'n v. EPA (CMA In), 899 F.2d 344, 360 (5th Cir. 1990) 
EPA's determination must be based on all of the factors that go into a determination of unreasonable risk, ${ }^{299}$ including the "reasonably ascertainable costs and other burdens associated with conducting tests in light of the possible risks of injury."300 Even the apparently simpler "substantial quantities" test has been held to require some consideration of toxicity to determine what is "substantial."301

The second and third findings under section 4 are that there exist "insufficient data and experience upon which the effects of [the chemical] can reasonably be determined or predicted," and that "testing ... is necessary to develop such data." 302 These two findings-that a data gap exists and that further testing would fill it-are minimal prerequisites to any rational testing program. Without a need for data and reason to believe that experimentation will meet this need, there is little point in requiring testing. Given the general lack of information, it would be highly unusual for EPA to be unable to support the latter two findings. ${ }^{303}$

(rule remanded); Chemical Mfrs. Ass'n v. EPA (CMA I), 859 F.2d 977, 984-88 (D.C. Cir. 1988) (rule upheld); Ausimont U.S.A. Inc. v. EPA, 838 F.2d 93, 96-97 (3d Cir. 1988) (rule upheld); Shell Chem. Co. v. EPA, 826 F.2d 295, 298 (5th Cir. 1987) (rule remanded). All except CMA II were "may present" cases. In the interest of full disclosure, I should note that while in private practice I assisted in the representation of CMA and some of its member companies in the Shell and CMA I cases. Needless to say, this Article contains no information that is even remotely confidential, and it is not intended to reflect the views of CMA, its members, or their lawyers.

299. See, e.g., EPA, Acrylamide: Response to the Interagency Testing Committee, 45 Fed. Reg. 48,510 (1980) (to be codified at 40 C.F.R. Ch. I); Chloromethane Test Rule, supra note 81 , at 48,528 . An excellent overview of the "may present" standard may be found in Hayes, New Life, supra note 9, at 64-65.

300. S. Rep. No. 698, supra note 72 , at 7 , reprinted in 1976 U.S. Code Cong. \& Admin. News at 4497; see also 15 U.S.C. $\$ 2603$ (b)(I) (1988) (requiring EPA to consider cost of testing in formulating test rules); Ausimont, 838 F.2d at 96 (noting that "Congress did not intend EPA to direct expensive experimentation based on mere speculation").

301. See EPA, Dichloromethane, Nitrobenzene and 1, 1, 1-Trichloroethane; Proposed Test Rule, 46 Fed. Reg. 30,300, 30,302 (1981) (to be codified at 40 C.F.R. pt. 773) (proposed June 5, 1981) [hereinafter Dichloromethane Test Rule]. But see CMA $I I, 899 \mathrm{~F} .2 \mathrm{~d}$ at 354 (substantiality not measured against risk by hypothetical toxicity).

302. 15 U.S.C. $§ 2603($ a)(1)(A)(ii)-(iii), (B)(ii)-(iii) (I988); see also EPA, Solid Waste Chemicals; Proposed Test Rule, 52 Fed. Reg. 20,336, 20,336 (1987) (to be codified at 40 C.F.R. pts. 795, 796, 799) (proposed May 29, 1987) (insufficient data); id. at 20,347 (need to test). EPA has occasionally withdrawn proposed test rules after comments showed that sufficient information existed to determine toxicity. See, e.g., EPA, Chloromethane; Withdrawal of Proposed Health Effects Test Rule, 50 Fed. Reg. 19,213, 19,218 (1985); EPA, Nitrobenzene; Decision to Withdraw a Proposed Rule, 49 Fed. Reg. $25,013,25,016$ (1984).

303. See Natural Resources Defense Council, Inc. v. EPA, 595 F. Supp. 1255, 1267 (S.D.N.Y. 1984) (unsuccessfully challenging EPA decision to issue test rule on ground that enough is already known to go ahead with regulation under section 6). EPA need not exhaust other information-gathering techniques before turning to section 4 , see EPA, Office of Solid Waste Chemicals; Final Test Rule, 53 Fed. Reg. 22,300, 22,304 (I988) (to be codified at 40 C.F.R. pts. 795, 796, 799), though it has done so, see, e.g., Dow Chem. Co. v. EPA, 605 F.2d 673, 677 (3d Cir. 1979). 
3. Evaluation. - The FIFRA and TSCA requirements to test have distinct advantages over the information acquisition techniques discussed in Part III. ${ }^{304}$ The most important of these advantages is newness of data. Lack of information is the regulatory prerequisite of a data call-in and of a test rule. Novelty also permits better quality assurance: bias aside, the producer of a chemical is in the best position to conduct testing due to its familiarity with the substance. With requirements to test, EPA can control the bias problem by closely supervising ex ante the protocols and by monitoring the actual testing. Thus, EPA has developed elaborate good laboratory practice and testing standards under both FIFRA and TSCA, ${ }^{305}$ which help to remedy the problems of validity or bias to which old data are subject. ${ }^{306}$

The cost to the government of requirements to test is minimal, except for the transaction costs of imposing them. It is also more equitable and efficient to shift the cost to makers and users of chemicals than to the public as a whole: equitable because the primary beneficiaries of the chemical pay for one of its externalities; efficient because, to the extent that the regulatory system internalizes costs (including the cost of detecting externalities), the price of the chemicals will more accurately reflect their true cost and consumption will adjust accordingly. Indeed, one justification given for data call-ins is that owners of marginally useful registrations will discontinue the product rather than pay for expensive research. ${ }^{307}$

Relevance and flexibility are the hallmarks of requirements to test. Both the data call-in and test rnle provisions give EPA complete discretion to target testing precisely to its regulatory needs and priorities. ${ }^{308}$ In deciding whether to require testing, EPA can consider the key risk factors of toxicity and exposure, as well as regulatory priorities, existing

304. See supra notes $215-277$ and accompanying text.

305. See 40 C.F.R. pts. 160, 792, 795-798 (1990).

306. See, e.g., Ausimont U.S.A. lnc. v. EPA, 838 F.2d 93, 96 (3d Cir. 1988) (parties questioning validity of data); Chemical Mfrs. Ass'n v. EPA (CMA I), 859 F.2d 977, 993, 995 (D.C. Cir. 1988) (parties raising validity and bias issues).

307. See Federal Insecticide, Fungicide, and Rodenticide Act Amendments of 1987: Hearings on H.R. 2463 Before the Subcomm, on Department Operations, Research, and Foreign Agriculture of the House Comm. on Agriculture, 100th Cong., 1st Sess. 34 (1987) (testimony of John A. Moore, Assistant Administrator of OPTS); 1985 House FIFRA Hearings, supra note 288, at 13 (testimony of John A. Moore, Assistant Administrator of OPTS).

308. See H.R. Rep. No. 1341 , supra note 35, at 17-18; see also 1985 House FIFRA Hearings, supra note 288, at 47-48 (John A. Moore, Assistant Administrator of OPTS, discussing uses of FIFRA data call-in); Toxic Substances Control Act: Hearings Before the Subcomm. on the Environment of the Senate Comm. on Commerce, 94th Cong., 1st Sess. 290 (1975) [hereinafter TSCA Hearings] (statement of William J. Bailey, president of American Chemical Society, supporting individual design of test rules); ATSDR/ HHS, supra note 224, at 5140 (describing ATSDR testing procedures). EPA has on a number of occasions declined to require testing because exposure was so minimal that even a finding of serious toxicity would not be cause for concern. See, e.g., EPA, Decision Not to Test Formamide, 5I Fed. Reg. 6929, 6930 (I986). 
information, and future information needs. Because EPA is faced with severely limited resources, a technique that permits the focusing of those resources in cost-effective programs has considerable merit. The flexibility of requirements to test also can reduce the absolute cost of testing by permitting a tiered or staged testing program that requires more expensive or long-term testing only on the basis of earlier tests that indicate some likelihood of effects. ${ }^{309}$ The only drawback in this respect is the high transaction cost of fine-tuning the requests.

Requirements to test do not cause the delays inherent in a licensing system. Because tests typically are undertaken prior to the imposition of regulatory restrictions, there is no immediate effect on the use of the chemical. Finally, requirements to test may be applied to almost any toxic chemical of concern and to almost any risk issue of interest.

\section{B. Improvements}

In considering how requirements to test could be improved in order to play a larger role in EPA's information policy, this Article concentrates on TSCA for the simple reason that FIFRA's coverage is limited to pesticides. While FIFRA should be used aggressively within its ambit, TSCA must be the basis for acquiring information on the broader range of toxic substances, which is, after all, what TSCA was designed to accomplish. ${ }^{310}$ TSCA's elegance is the creation of a regulatory structure that can acquire a variety of existing data from the whole spectrum of chemical producers and processors, and permits the creation of new data when needed. The TSCA approach requires at least minimal rationality in establishing test rules (need and relevance), and the ITC criteria for setting priorities fit risk assessment needs. Finally, TSCA was Congress's recent choice in establishing cost-recovery gnidelines for ATSDR. ${ }^{311}$

Unfortunately, only a handful of test rules have been promulgated

309. See Ahmed \& Dominguez, The Development of Testing Requirements Under the Toxic Substances Control Act, in Environmental Risk Analysis for Chemicals 506, 509 (R. Conway ed. 1982); Weinstein, supra note 9, at 367-72. In fact, most data callins and test rules do adopt a tiering approach. See, e.g., EPA, Mouse Visible Specific Locus Test Requirement; Final Amendment in Test Rules, supra note 253, at 12,640; EPA, Toxicology Data Call-In for Antimicrobial Pesticides, supra note 289, at 595. There are, however, limits to tiering-some tests (for example, for different effects) must be undertaken simultaneously so that testing is completed within a reasonable amount of time. Chloromethane Test Rule, supra note 81 , at 48,528 (estimating that purely sequential testing would double test period from 4-1/2 to 9 years).

310. See 15 U.S.C. $\S 2601$ (b)(1) (1988) (policy of TSCA); TSCA Hearings, supra note 308, at 193 (testimony of Russell W. Peterson, chairman of CEQ); S. Rep. No. 698, supra note 72, at 2-3, reprinted in 1976 U.S. Code Cong. \& Admin. News at 4492-93; H.R. Rep. No. 1341, supra note 35, at 17; The President's 1971 Environmental Program: The President's Message to the Congress Outlining His Program, 7 Weekly Comp. Pres. Doc. 187, 194 (Feb. 15, 1971) (remarks of Pres. Ford on signing TSCA).

311. 42 U.S.C. \& 9604(i)(5)(D) (1988); see H.R. Rep. No. 253, supra note 195, pt. 5, at 33, reprinted in 1986 U.S. Code Cong. \& Admin. News at 3156; S. Rep. No. Il, 
under TSCA. ${ }^{312}$ EPA's inaction is best explained by the elaborate procedural barriers that confine the test rules. In addition to the procedure outlined above, ${ }^{313}$ EPA must support each rule under the relatively strict "substantial evidence" standard of judicial review. 314 At the very least, these procedural hurdles provide a basis for challenging TSCA test rules and render their promulgation a time-consuming and expensive process. Section 4 should be made more effective in its current function and more suitable for use in other areas of the regulation of toxic substances.

1. Unreasonable Risk. - The most frequently used part of the initial finding under section 4 of TSCA requires EPA to impose a test rule if it finds that the chemical "may present an unreasonable risk of injury to health or the environment." 315 One of the major strengths of section 4 is the direct relevance of this finding to the ultimate regulatory standard. EPA must decide whether to promulgate a test rule in terms of the unreasonable risk criterion for regulatory action under section 6 . By the same token, however, one of the major weaknesses of section 4 is the complexity of the unreasonable risk standard. Unreasonable risk, we have seen, requires case-by-case consideration of toxicity, exposure, and cost factors. ${ }^{316}$ Congress assumed that all of these factors would be relevant to the decision whether to promulgate a TSCA test rule, ${ }^{317}$ and the courts have agreed. ${ }^{318}$ In keeping with its usual approach to unreasonable risk, EPA announced in its first test rule that it would divide the unreasonable risk analysis into three steps: hazard (toxicity), risk (toxicity $\mathrm{x}$ exposure), and unreasonable risk (a nonzero level of risk). ${ }^{319}$ The result, predictably, is a kind of quantitative risk assessment even before testing can occur. Equally predictably, industry supported this "selective" approach. ${ }^{320}$ The Natural Resources Defense

supra note 187 , at $27,30,33$; H.R. Conf. Rep. No. 962, supra note 56 , at 208-12, reprinted in 1986 U.S. Code Cong. \& Admin. News at 3301-05.

312. By the end of fiscal year 1989, EPA had received full test data for only six chemicals and had not completed review of the data for any. Government Accounting Office, Toxic Substances: EPA's Chemical Testing Program Has Made Little Progress 20-21 (1990) [hereinafter Chemical Testing Program].

313. See supra notes $278-303$ and accompanying text.

314. 15 U.S.C. $\$ 2618(c)(1)(B)(1988)$.

315. Id. $\S 2603(\mathrm{a})(1)(\mathrm{A})(\mathrm{i})$.

316. See supra notes $72-86$ and accompanying text.

317. H.R. Rep. No. 1341, supra note 35, at 13-14; S. Rep. No. 698, supra note 72, at 6-7, reprinted in 1976 U.S. Code Cong. \& Admin. News at 4496-97; H.R. Conf. Rep. No. 1679 , supra note 38 , at 60-61, reprinted in 1976 U.S. Code Cong. \& Admin. News at $4544-46$.

318. See Ausimont U.S.A. Inc. v. EPA, 838 F.2d 93, 96-97 (3d Cir. 1988); see also Environmental Defense Fund, Inc. v. EPA, 636 F.2d 1267, 1276-77 (D.C. Cir. 1980) (discussing the relevance of "economic consequences" of testing versus regulation).

319. Chloromethane Test Rule, supra note 81 , at 48,528-29.

320. TSCA Hearings, supra note 308, pt. 2, at 103 (testimony of G. Dominguez, Manufacturing Chemists Ass'n) (advocating "the exercise of thoroughly justified and careful discrimination by EPA"). 
Council, however, has said that the unreasonable risk standard cripples section $4,{ }^{321}$ and a Congressional study has concluded that the complex, multifactored analysis required by the unreasonable risk standard is at least in part responsible for EPA's relative inaction under section 6.322

Unreasonable risk should be replaced in the section 4 context by a more readily satisfied, less complex standard-something, in short, with less baggage. The term "unreasonable" should be dropped. The appropriate level (as opposed to existence) of risk is a policy question and more suitable in the standard-setting stage than in data collection. Under section 4, EPA should be exploring policy options, not setting policy. Reasonable restraint by EPA can be assured by the existing provision requiring cost-effective testing ${ }^{323}$ and by the usual understanding that the term "risk" standing alone does not include de minimis risks. ${ }^{324}$

Furthermore, EPA should be permitted to infer the existence of a risk from either of its components, toxicity or exposure. If one accepts the statistical concept of risk (i.e., that toxicity is measured by degree of collective risk), ${ }^{325}$ then a chemical with rare effects and mass exposure will cause as many deaths as one with high toxicity and low exposure. High toxicity or high exposure are of equal concern, therefore, and each ought to trigger testing. Arguably, this approach was the original basis for the two prongs of section 4: "may present" was to be primarily a toxicity finding and "substantial exposure" an exposure finding. ${ }^{326}$ In addition, EPA's "weight of the evidence" interpretation of the "may present" standard permits a test rule to be issued when toxicity evidence is weak but exposure evidence is strong, and vice versa. ${ }^{327}$ By contrast, the logic of requiring both toxicity and exposure evidence for a

321. What Ever Happened to the Toxic Substances Control Act?: Hearing Before the Subcomm. on Environment, Energy, and Natural Resources of the House Comm. on Government Operations, 100th Cong., 2d Sess. 95-101 (1988) (statement of Jacqueline Warren, NRDC), cited in Hayes, New Life, supra note 9, at 72; see also TSCA Hearings, supra note 308, at 140 (testimony of Linda Billings of Sierra Club suggesting likelihood of litigation and delays under this standard).

322. Government Accounting Office, Toxic Substances: Effectiveness of Unreasonable Risk Standards Unclear 4-6 (1990).

323. 15 U.S.C. § 2603(b)(1) (1988); see also H.R. Rep. No. 1341, supra note 35, at 19 (directing EPA to minimize testing costs).

324. In the absence of clear direction otherwise, "risk" is uniformly interpreted to exclude de minimis risks. See, e.g., Industrial Union Dep't, AFL-ClO v. American Petroleum Inst. (the Benzene case), 448 U.S. 607, 614-15, 639-43 (1980) (plurality) (interpreting OSHA §§ 3(8), 6(b)(5)); Aqua Slide 'N' Dive Corp. v. Consumer Prod. Safety Comm'n, 569 F.2d 83I, 840 (5th Cir. 1978) (interpreting CPSA); D.D. Bean \& Sons Co. v. Consumer Prod. Safety Comm'n, 574 F.2d 643, 651 (1st Cir. 1978).

325. See supra note 14 and accompanying text.

326. Compare 15 U.S.C. $\S 2603(\mathrm{a})(\mathrm{l})(\mathrm{A})(\mathrm{i})$ ("may present an unreasonable risk") with id. $\S 2603(a)(1)(B)(i)$ ("substantial human exposure").

327. Chloromethane Test Rule, supra note 81 , at 48,529 . 
test rule is, first, to limit generally EPA activity under section 4 , and second, to replicate in a less demanding way the section 6 standard for substantive regulatory control. While it is an excellent practice to keep the section 6 regulatory standard in mind at the testing stage, there is no reason that testing itself could not be based on part of that standard.

2. May Present. - At first glance, the rigor of the unreasonable risk standard is ameliorated by the "may present" language in section 4 . Congress obviously intended that the section 6 regulatory standard be relaxed ("may present an unreasonable risk" versus "presents or will present an unreasonable risk") when only testing is involved. ${ }^{328}$ The phrase "may present," however, has proven to be anything but a relaxed and flexible standard.

As an initial matter, explaining precisely what "may present" means is difficult. The legislative history and the cases are full of different explanatory or interpretive phrases: "basis for concern,"329 "existing possibility of harm,"330 and a "more-than-theoretical basis" for concluding that a substance does present an unreasonable risk. ${ }^{331}$ But what do these terms mean in operation? Clearly, testing is meant to be selective in the sense that not all chemicals meet the "may present" standard. ${ }^{332}$ In addition, it must not be based on "mere conjecture or speculation" or hunches. ${ }^{333}$ But at the same time, EPA must "demonstrate . . . doubt and uncertainty" with substantial evidence. ${ }^{334}$

This ambiguity has generated a debate before the courts regarding the showing of exposure needed to justify a test rnle. Given the importance of exposure to any risk finding, EPA properly conceded early on that "toxicity is of little concern to EPA if there is no human exposure to the chemical."335 Industry took the position that proof of actual exposure was required, while EPA argued that only potential exposure need be shown. ${ }^{336}$ The courts rejected the need for a showing of actual exposure or for proof that an unreasonable risk was more probable

328. See H.R. Rep. No. 1341, supra note 35, at 14-15; Chemical Mfrs. Ass'n v. EPA (CMA I), 859 F.2d 977, 984-86 (D.C. Cir. 1988); Chloromethane Test Rule, supra note 81 , at 48,529 .

329. H.R. Rep. No. 1341, supra note 35, at 17; H.R. Conf. Rep. No. 1679, supra note 38, at 61, reprinted in 1976 U.S. Code Cong. \& Admin. News at 4546.

330. Ausimont U.S.A. Inc. v. EPA, 838 F.2d 93, 97-98 (3d Cir. 1988).

331. CMA I, 859 F.2d at 979.

332. See Shell Chem. Co. v. EPA, 826 F.2d 295, 297 (5th Cir. 1987); Ausimont, 838 F.2d at 96 .

333. H.R. Rep. No. 1341, supra note 35, at 18.

334. Ausimont, 838 F.2d at 96.

335. Chloromethane Test Rule, supra note 81 , at 48,528 .

336. EPA, Office of Solid Waste Chemicals; Final Test Rule, supra note 303, at 22,303; see also Chloromethane Test Rule, supra note 81, at 48,528 (stating EPA's position); Chemical Mfrs. Ass'n v. EPA (CMA I), 859 F.2d 977, 984 (D.C. Cir. 1988) (describing CMA's position). 
than not. ${ }^{337}$ But EPA must still make a case for exposure or potential exposure, and industry has repeatedly made this requirement a centerpiece of its "may present" challenges. 338

Much of the confusion results from the proliferation of probabilistic criteria under section 4. Professor Page has demonstrated that, in assessing toxic hazards in civil litigation, a court must evaluate probabilities of probabilities. That is, the court must decide whether it is more likely than not (a probability) that exposure to a particular substance caused (also a statistical relationship in the context of toxic substances) a particular illness. These "second order probabilities" are manageable, if complex. ${ }^{339}$ But TSCA demands more. The regulatory end-point is a probability (risk), and the standard of review (substantial evidence) can also be expressed as a probability. So far, it follows Page's model. The term "may present," however, adds a further probabilistic qualification to the standard. Test rules, then, are founded on a third order probability: EPA must promulgate a test rule when it finds a probability (substantial evidence) of a probability (may present) of a probability (risk). Moreover, each probability is a very different type of calculation: risk is a statement of frequency of effect; "may present" is a statement of the confidence in the induction from known data to frequency; and substantial evidence is a statement of the overall certainty with which the foregoing statements are made. Risk and "may present" take an $e x$ ante perspective; substantial evidence is an ex post evaluation. The "may present" prong of the first section 4 finding, in sum, cannot be made simple, and it constitutes a major obstacle to the smooth functioning of the TSCA requirement to test.

A better approach would be to replace the "may present" standard with a paraphrase of F1FRA's data call-in language, "if the Administrator determines that additional data are required." For more detailed guidance, a list of factors that the agency must consider (for example, the degree of risk, the amount of exposure, and the cost of testing) could be added to the basic formulation. If even more direction seems advisable, TSCA could distinguish between levels of consideration that must be given to particular factors. For example, toxicity and exposure could be matters of primary concern and cost only secondary. ${ }^{340}$

337. CMA I, 859 F.2d at $983-84,989$; see also Ausimont, 838 F.2d at 97 (agency may act "when existing possibility of harm raises legitimate concerns").

338. See Shell Chem. Co. v. EPA, 826 F.2d 295, 297-98 (5th Cir. 1987) (remanding for further exposure information); CMA I, 859 F.2d at 988-90, 992-94; Ausimont, 838 F.2d at 96-97.

339. Page, On the Meaning of the Preponderance Test in Judicial Regulation of Chemical Hazard, Law \& Contemp. Probs., Summer 1983, at 267, 276-83.

340. See, e.g., Weyerhaeuser Co. v. Costle, 590 F.2d 1011, 1044-47 (D.C. Cir. 1978), indicating that the Clean Water Act, 33 U.S.C. $§ 1314$ (b)(1)(B) (1976), distinguishes between "comparison factors," to which the agency is to give primary weight ("a level of greater attention and rigor"), and "consideration factors," a list of several fac. tors which the agency is to "take into account" but in no particular order or relative 
Either way, this model provides a sufficient basis for effective judicial review, but without the distractions of the current "may present" terminology. ${ }^{341}$

3. Surrogate Standards. - A further refinement of section 4 would be to replace the unreasonable risk standard with "surrogate" standards, that is, relatively easily proven facts that are indicative of longterm toxicity and exposure, which in turn are indicative of unreasonable risk. TSCA to some extent already adopts a surrogate standard as an alternative to the initial "may present an unreasonable risk" finding. Testing is required when EPA finds (in addition to inadequate information and the need for testing) that:

a chemical substance or mixture is or will be produced in substantial quantities, and (1) it enters or may reasonably be anticipated to enter the environment in substantial quantities or (II) there is or may be significant or substantial human exposure to such substance or mixture . . . .342

In effect, health risks are presumed from substantial levels of production and exposure. ${ }^{343}$

Superficially, this alternative to the "may present an unreasonable risk" standard looks like a tidy, one-stage process. Production serves as a surrogate for exposure, and exposure raises a presumption of risk for testing purposes. Congress may well have conceived of this language in those terms. However, as written and subsequently interpreted, the actual standard for testing is hardly simple. EPA is required by the statute to make specific findings regarding actual production and potential exposure either to the environment or to humans. Even though EPA can make these findings relying solely on exposure data and not on toxicity information, ${ }^{344}$ each element permits challenges to EPA's rulemaking. Actual production data, while relatively straightforward,

importance. The more elaborate National Contingency Plan scheme for remedy selection identifies three tiers of criteria: threshold, balancing, and modifying. National Contingency Plan, supra note 57, at 8850 (to be codified at 40 C.F.R. $\$ 300.430$ (f)).

TSCA itself already treats cost of testing as a generalized "consideration" factor. 15 U.S.C. § 2603(b)(1) (1988) ("In determining the standards and period to be included [in a test rule], ... the Administrator's considerations shall include the relative costs of the various test protocols and methodologies .....").

341. Listing appropriate factors is a standard statutory technique. See, e.g., Motor Vehicle Mfrs. Ass'n v. State Farm Mut. Auto. Ins. Co., 463 U.S. 29, 42-43 (1983) (agency must consider all relevant factors and only relevant factors).

342. 15 U.S.C. $\S 2603(\mathrm{a})(1)(\mathrm{B})(\mathrm{i})$ (1988) (emphasis added).

343. See S. Rep. No. 698, supra note 72, at 15-16, reprinted in 1976 U.S. Code Cong. \& Admin. News at 4505-06; see also H.R. Conf. Rep. No. 1679, supra note 38, at 61, reprinted in 1976 U.S. Code Cong. \& Admin. News at 4546 ("testing should be conducted even though there is an absence of information indicating that the substance or mixture per se may be hazardous").

344. Chemical Mfrs. Ass'n v. EPA (CMA II), 899 F.2d 344, 357-59 (5th Cir. 1990); H.R. Conf. Rep. No. 1679, supra note 38, at 61, reprinted in 1976 U.S. Code Cong. \& Admin. News at 4546 (regulation in absence of toxicity data); Dichlorometbane Test Rule, supra note 301, at 30,302 (second test rule, still relied upon). 
must be demonstrated by substantial evidence, as must releases into the environment. ${ }^{345}$

A more serious problem is raised by the meaning of "substantial" and "significant" in clauses (1) and (11). As with the level of risk that is to be deemed "unreasonable," TSCA gives no indication of how to define these terms or how EPA is to determine that the standards are satisfied. EPA has been vagne about defining them, preferring to resort to case-by-case decision making (again, like unreasonable risk). ${ }^{346}$ Indeed, the Fifth Circuit recently remanded a test rule primarily on the ground that EPA had failed to articulate "standards or criteria . . . either for application generally or to this particular case."347 This ruling effectively halts promulgation of test rules based on production and exposure (at least ones that can be reviewed in the Fifth Circuit, which is the home of a large part of the chemical industry ${ }^{348}$ ) until EPA comes up with some criteria for making this determination. The Fifth Circuit's interpretation of the statute flows naturally from the Benzene analysis ${ }^{349}$ and is certainly a plausible interpretation of the intricate statutory language. Its effect, however, is to make promulgation of "substantial quantities" test rules needlessly complex.

TSCA ought to permit EPA to avoid the burdensome case-by-case development of test rules-which Congress's use of terms like "unreasonable," "substantial," and "significant" invites-by relying solely on well understood and easily accessible surrogate factors. Admittedly, surrogate standards are blunt instruments and tend to be overinclusive. Nevertheless a manufacturer always has the opportunity during the rulemaking proceedings to persuade EPA that testing is unnecessary, and truly irrational agency action is subject to reversal even under limited judicial review. Neither the flexibility of test rules nor the standard for regulatory action would be affected by surrogate standards. The only difference from the present TSCA would be the effort required to justify the testing requirements.

A number of surrogate standards suggest themselves. Production quantity alone can be a surrogate for exposure, which is part of the risk equation. If "substantial quantities" were generically set by Congress

345. CMA II, $899 \mathrm{~F} .2 \mathrm{~d}$ at 353-54 (remanding test rule in part to clarify whether aquatic exposure, which EPA had failed to prove, was part of overall finding of entering environment in substantial quantities).

346. See Dichloromethane Test Rule, supra note 301 , at 30,302 .

347. CMA II, 899 F.2d at 357-60.

348. See J. McPhee, The Control of Nature 6 (1989) (describing the lower Mississippi River as " 'the American Ruhr" "). Houston and its port Galveston, other major centers of the chemical industry, are also located in the Fifth Circuit.

349. Industrial Union Dep't, AFL-CIO v. American Petroleum Inst. (the Benzene case), 448 U.S. 607, 642 (1980) (plurality) (requiring threshold finding of "significant risk"); see also Natural Resources Defense Council, Inc. v. EPA (the Vinyl Chloride case), 824 F.2d 1146, 1164-65 (D.C. Cir. 1987) (en banc) (requiring threshold determination of what is "safe" level of vinyl chloride emissions). 
or EPA at a fixed amount, the process would be simplified still further. ${ }^{350}$ Indeed, a proposed amendment of TSCA required testing for all large-volume chemicals. ${ }^{351}$ Turning to the other half of the risk equation, acute toxicity and structure-activity relationships can be surrogates for chronic toxicities, including carcinogenicity. Evidence of high acute toxicity is some indication that longer term effects may occur. This factor is one of the criteria already used by EPA to determine whether to initiate full review of registered pesticides. ${ }^{352}$ Similarity in structure or activity to chemicals with known health effects also supports the inference of toxicity. The strength of the inference is subject to some debate, ${ }^{353}$ but EPA regularly considers it in assessing potential toxicity for test rules. ${ }^{354}$ Congress and the courts have accepted it as at least a partial basis for test rules. ${ }^{355}$ In fact, TSCA specifically authorizes EPA to regulate categories of chemicals on the basis of similar "molecular structure [or] physical, chemical, or biological properties."356 Both acute effects data and structure-activity information tend to be readily available or at least fairly cheaply obtainable-in short, promising surrogate standards.

4. Substantial Evidence. - Judicial review under heightened scrutiny is a final reason that the TSCA process is lengthy and underused. Judicial review, of course, is not a bad idea. Test rules can cost upwards of one million dollars, so there is real value to assuring that the decisions

350. EPA could use the procedure currently in place for setting threshold reporting quantities. 42 U.S.C. § 11023 (f) (1988) (EPCRA); EPA, Community Right-to-Know Release Reporting; Addition of Certain Chemicals, 54 Fed. Reg. 16,138, 16,139 (1989) (proposed Apr. 21, 1989).

351. See S. 3075, 98th Cong., 2d Sess. $\$ 4$ (b) (1984) (testing required for any chemical if 100 million or more pounds produced, sold, or imported per year).

352. 40 C.F.R. § 154.7(a) (1990); see also EPA, Regulations for the Enforcement of the Federal Insecticide, Fungicide and Rodenticide Act; Registration, Reregistration, and Classification Procedures, 40 Fed. Reg. 28,242, 28,281-82 (1975) (acute toxicity is factor to be considered in canceling pesticide registration); Spector, supra note 274 , at 253 (under new regulations, high acute toxicity level and observed chronic toxicity effects raise presumption against pesticide).

353. See Josephson, Toxic Substances Information Development, 14 Envtl. Sci. \& Tech. 772 (1980); Toxicity Testing, supra note 6, at 308.

354. See, e.g., EPA, Methyl Ethyl Ketoxime; Final Test Rule, 54 Fed. Reg. 37,799, 37,800 (1989) (to be codified at 40 C.F.R. pt. 799); EPA, Fluoroalkenes; Final Test Rule, 52 Fed. Reg. 21,516, 21,519-20 (1987) (to be codified at 40 C.F.R. pt. 799); Slesin \& Sandler, supra note 126, at 391-93 (describing use by ITC in prioritizing).

355. H.R. Rep. No. 1341, supra note 35, at 17; Ausimont U.S.A. Inc. v. EPA, 838 F.2d 93, 96 (3d Cir. 1988) (in addition to other evidence); Chemical Mfrs. Ass'n v. EPA (CMA I), 859 F.2d 977, 995-96 (D.C. Cir. 1988) (in addition to other evidence of toxicity); see also Slesin \& Sandler, supra note 126, at 390-91 (arguing that structure-activity relationships should meet "may present" test).

356. 15 U.S.C. $§ 2625$ (c)(2)(A) (1988); see also Slesin \& Sandler, supra note 126, at 389-94 ("categorization facilitate[s] the control of toxic substances under TSCA"). EPA has not, however, used this authority for test rules. See EPA, Office of Solid Waste Chemicals; Final Test Rule, supra note 303, at 22,302 (disclaiming reliance on categorization for EPA's multichemical test rule). 
are not made capriciously. Moreover, if Congress is going to go to the trouble of specifying prerequisites to a test rule-and rational ones, at that-it is only sensible to enforce them, if only to be sure that EPA is not squandering scarce resources. Nevertheless, the substantial evidence standard adopted for judicial review of TSCA test rules exacerbates the complexity of the unreasonable risk and "may present" standards. The result has been that if industry merely raises doubts about several elements of the unreasonable risk standard and the meaning of "may present," the courts must be receptive to the challenges. ${ }^{357}$

The judicial review provision for section 4 exemplifies hybrid rulemaking. The standard of judicial review for formal, trial-like adjudication ("substantial evidence in the rulemaking record ... taken as a whole"358) is applied to what is fundamentally informal rulemaking that ordinarily would be subject to the "arbitrary, capricious" standard. 359 The exact difference in degree of judicial scrutiny between the substantial evidence and arbitrary, capricious standards is anything but clear, and it may be nonexistent. ${ }^{360}$ Yet substantial evidence retains "a vague

357. See, e.g., Chemical Mfrs. Ass'n v. EPA (CMA II), 899 F.2d 344, 357-60 (5th Cir. 1990) (remanding because substantial evidence standard requires that EPA address each statutory factor with clarity and precision); Shell Chem. Co. v. EPA, 826 F.2d 295, 297-98 (5th Cir. 1987) (remand appropriate in close case under substantial evidence review).

358. 15 U.S.C. $\S 2618(\mathrm{c})(1)(\mathrm{B})(\mathrm{i})(1988)$.

359. 5 U.S.C. $\$ 706(2)$ (A), (E) (1988). See H.R. Conf. Rep. No. 1679, supra note 38, at 96, reprinted in 1976 U.S. Code Cong. \& Admin. News at 4581 ("The conferees recognize that in rulemaking proceedings such as those contained in this bill, which are essentially informal and which involve both determinable facts and policy judgments derived therefrom, the traditional standard for review is that of 'arhitrary and capricious.' ").

TSCA's judicial review section appears to have been virtually copied from the Consumer Product Safety Act of 1972, 15 U.S.C. \& 2060(c) (1988), which in turn had antecedents in OSHA, 29 U.S.C. $\S 655(f)$ (1988). See Scalia \& Goodman, Procedural Aspects of the Consumer Product Safety Act, 20 UCLA L. Rev. 899, 933-34 (1973). Like CPSA, the TSCA provision wears the stripes of a legislative compromise. See id. at 935-36; cf. Shapiro \& McGarity, supra note 23, at 12 \& n.68 (making the same observation about the similar OSHA provision). The courts have frequently noted the difficulties of applying a formal standard of review to an informal record. See, e.g., Aqua Slide 'N' Dive Corp. v. Consumer Prod. Safety Comm'n, 569 F.2d 831, 837 (5th Cir. 1978); Industrial Union Dep't, AFL-CIO v. Hodgson, 499 F.2d 467, 476 (D.C. Cir. 1974).

360 . Scalia and Goodman have argued persuasively that there ought to be no difference in degree of scrutiny and that the main difference between them should be reliance on an exclusive record. Scalia \& Goodman, supra note 359, at 934-36; see also Association of Data Processing Serv. Orgs. v. Board of Governors of the Fed. Reserve Sys., 745 F.2d 677, 683 -86 (D.C. Cir. 1984) (Scalia, J.) (stating that the operation of each standard is "precisely the same"); Note, Convergence of the Substantial Evidence and Arbitrary and Capricious Standards of Review During Informal Rulemaking, 54 Geo. Wash. L. Rev. 541, 548-61 (1986) (collecting cases to illustrate similarity of standards). 
reputation as the more demanding" standard, ${ }^{361}$ and expresses, in Frankfurter's words, a critical "mood."362 Indeed, Congress intended that the substantial evidence requirement in TSCA indicate a greater degree of scrutiny, ${ }^{363}$ and the courts interpreting section 4 have obliged. ${ }^{364}$ Substantial evidence is in fact a virtual invitation to the courts to substitute their judgment for EPA's. ${ }^{365}$

Even if TSCA's substantial evidence language were understood to refer only to exclusive-record review and not to degree of scrutiny, ${ }^{366}$ section 4 rulemaking does not provide the proper kind of record. ${ }^{367}$ In other areas of high uncertainty "on the frontiers of scientific knowledge," 368 courts have coped with this dissonance by resorting to arbitrary, capricious review. In Industrial Union Department, AFL-CIO $v$. Hodgson, 369 the D.C. Circuit stated, "when the Secretary is obliged to make policy judgments where no factual certainties exist or where facts alone do not provide the answer, he should so state and go on to identify the considerations he found persuasive." 370 The substantial evi-

361. Scalia \& Goodman, supra note 359 , at 934 . The pervasiveness of this reputation is epitomized in Environmental Defense Fund, lnc. v. EPA, 636 F.2d 1267, 1277 \& n.28 (D.C. Cir. 1980), in which the court recognized that substantial evidence "is generally considered to be more rigorous," yet dropped a "but see" footnote stating the contrary.

362. Universal Camera Corp. v. NLRB, 340 U.S. 474,487 (1951).

363. H.R. Rep. No. 1341, supra note 35 , at 56 (the Committee intends that the reviewing court engage in a "searching review").

364. See, e.g., Ausimont U.S.A. lnc. v. EPA, 838 F.2d 93, 96 (3d Cir. 1988); Chemical Mfrs. Ass'n v. EPA (CMA I), 859 F.2d 977, 991-92 (D.C. Cir. 1988); Shell Chem. Co. v. EPA, 826 F.2d 295, 297 (5th Cir. 1987). Indeed, CMA's whole argument that EPA could not rebut actual exposure data with inferences was based in part on the "may present" standard and in part on the "substantial evidence" standard. See CMA I, 859 F.2d at $984-89,991-92$.

365. Shapiro \& McGarity, supra note 23, at 9-10, 50-52 (finding that substantial evidence review is major source of OSHA's inaction).

366. See H.R. Conf. Rep. No. 1679, supra note 38, at 96, reprinted in 1976 U.S. Code Cong. \& Admin. News at 4581 ("substantial evidence" test adopted so that courts "focus on the rulemaking record").

367. The record required by TSCA, 15 U.S.C. $\$ \S 2603(b)(5), 2618(a)(3)$ (1988), includes "any other information which the Administrator considers to be relevant to such rule." There is little formality to this record, and there are no exclusivity provisions. The Senate Report acknowledged that "widely accepted scientific principle or fact" need not be included in the record; rather, in those cases "agency expertise is definitive so that an extensive record need not be developed." S. Rep. No. 698, supra note 72, at 27, reprinted in 1976 U.S. Code Cong. \& Admin. News at 4517.

368. Industrial Union Dep't, AFL-CIO v. Hodgson, 499 F.2d 467, 474 (D.C. Cir. 1974).

369. 499 F.2d 467 (D.C. Cir. 1974).

370. Id. at 476; see also id. at 472-76 (discussing difficulty of applying substantial evidence standard to informal record and uncertain facts); Ethyl Corp. v, EPA, 541 F.2d 1, 26-29 (D.C. Cir. 1976) (en banc) (affirming Hodgson approach in considering lessthan-conclusive evidence used to support reductions in lead in gasoline under Clean Air Act), cert. denied, 426 U.S. 941 (1976); Levin, Scope-of-Review Doctrine Restated: An Administrative Law Section Report, 38 Admin. L. Rev. 239, 253-55, 270-72, 274-75 
dence standard simply is not very useful when there are few facts against which factual accuracy can be measured. ${ }^{371}$

Congress recognized this paradox and apparently expected the courts to adopt a Hodgson-like deferential use of substantial evidence in section $4 .{ }^{372}$ But the problem with section 4 is not so easily resolved. TSCA requires the agency, as one court put it, "to demonstrate ... doubt and uncertainty." 373 It is almost inconceivable that this factor could be proven by substantial evidence-evidence is precisely what is lacking. ${ }^{374}$ The incompleteness or invalidity of information can be asserted only by reference to the agency's expertise and general knowledge in the area. Studies reaching this conclusion-i.e., record evidence-are extremely unlikely to exist in any but a small minority of cases. ${ }^{375}$

A higher standard of review is exactly the wrong direction to take in reviewing the acquisition of data. It runs counter to the intended relaxation of the regulatory standard in the use of "may present." Even if some incremental benefit would be achieved in accuracy of testing determinations, it could not be worth the additional cost of litigation engendered by the heightened scrutiny. ${ }^{376}$ Substantial evidence also forces EPA to spend excessive amounts of time preparing a record to withstand judicial review. ${ }^{377}$ If Congress takes seriously the need to obtain more data, the transaction costs of doing so should be minimized. The arbitrary, capricious standard has shown itself adequate to

(1986) (distinguishing policy judgments reviewed under arbitrary, capricious standard from factual findings reviewed for substantial evidence).

371. McGarity, supra note 20 , at 792, 809-10.

372. See H.R. Rep. No. 1341, supra note 35, at 55-56 \& n.l (citing Hodgson favorably). Sen. Magnuson, a chief sponsor of TSCA, reported to the Senate:

While the "substantial evidence" review extends to rules under section 4(a), it is not anticipated that this review standard will unduly hinder the Administrator. As testing requirements under section 4(a) will frequently be based on an insufficiency of data, it would ordinarily not be appropriate for the Administrator to develop "substantial evidence" of that insufficiency.

122 Cong. Rec. 32,854 (1976) (urging adoption of the Conference Report on TSCA).

373. Ausimont U.S.A. Inc. v. EPA, 838 F.2d 93, 96 (3d Cir. 1988) (emphasis added); accord, Chemical Mfrs. Ass'n v. EPA (CMA I), 859 F.2d 977, 985-86 (D.C. Cir. 1988) (uncertainty argues in favor of testing, not against it); cf. Chemical Mfrs. Ass'n v. EPA (CMA II), 899 F.2d 344, 354 (5th Cir. 1990) ("general uncertainty about chemicals and their effects is a major theme of the statute") (emphasis omitted).

374. Recall Sen. Maguuson's remarks, supra note 372. It is at the very least questionable whether Sen. Magnuson's understanding of the bill is reflected in the bill's langnage.

375. This problem would not occur in truly formal proceedings because EPA's assertions of lack or invalidity of information would be presented in testimony and subject to cross-examination. The court could then evaluate that record exclusively. A comparison of the APA's formal procedures with TSCA's shows how far TSCA is from a proper use of the substantial evidence standard.

376. Cf. Latin, Regulatory Efficiency, supra note 4, at 1307-09, 1324-31 (arguing that agencies cannot make accurate, individualized determinations with respect to toxic risks without incurring prohibitive transaction costs).

377. Cf. Shapiro \& McGarity, supra note 23, at 41-42 (discussing OSHA). 
detect regulatory abuse, ${ }^{378}$ and it retains the flexibility that is one of the major substantive advantages of requirements to test. In addition, with its emphasis on consideration of relevant factors, the arbitrary, capricious standard matches the statutory model, proposed above, ${ }^{379}$ of a flexibly structured group of factors.

More dramatic changes are also possible. It has been suggested that TSCA should require manufacturers to justify not testing any chemical ${ }^{380}$ or, more modestly, that the burden of proof should be shifted to manufacturers once a chemical has been recommended for testing by the ITC. ${ }^{381}$ The former could make sense in the context of a licensing process in which adequate data is a prerequisite to sale and use, but it would not be well suited to the present TSCA scheme of $e x$ post regulation. The latter would in effect create a rebuttable presumption in favor of testing based on a preliminary agency finding. As such, it would be an extension of the changes in judicial review suggested here. It still might be too much to expect EPA to be able to meet deadlines for refusing data, in which case EPA would either accept more than it can manage or institute across-the-board delays. Even so, a presumption for testing would eliminate one of the biggest hurdles that TSCA places in the way of a rational information policy.

CERCLA provides a useful comparison with section 4, as it embodies many of the above suggestions. Like TSCA, CERCLA uses "may present" language in its authorization to EPA to add chemicals to the list of covered substances and to establish reportable quantities for them. ${ }^{382}$ In addition, CERCLA incorporates both factors of the risk equation, using the term "substantial danger." 383 Yet EPA has been able to use the CERCLA provision with frequency and without notable judicial interference. One reason, no doubt, is that listing has few immediate costs and is several steps removed from substantive regulatory restrictions, so industry has less incentive to mount challenges. Nevertheless, it is worth noting that CERCLA avoids the term "unreasonable risk" in favor of "substantial danger," a deliberately "lower threshold" that was "intended to afford the President broad discretion in desiguating substances which may adversely affect public health or the environ-

378. See, e.g., Motor Vehicle Mfrs. Ass'n v. State Farm Mut. Auto. Ins. Co., 463 U.S. 29, 34 (1983) (invalidating agency regulations under arbitrary, capricious standard).

379. See supra notes 340-341 and accompanying text.

380. Russell W. Peterson, Chairman of Council on Environmental Quality (CEQ), originally sought to place the burden on the chemical manufacturer, not EPA. Hearings on S. 776 Before the Subcomm. on the Env't of the Senate Comm. on Commerce, 94th Cong., Ist Sess., pt. I, at 193 (1975). The PMN is a faint reflection of Peterson's view; section 4 does not reflect it at all.

381. This proposal has been made in Congress. See S. 3075, supra note 35I, $\S \S 4-5$ (1984); H.R. 4304, 98th Cong., Ist Sess. (1983).

382. 42 U.S.C. $\$ 9602$ (a) (1988).

383. Id. 
ment."384 In addition, the relevant factors and their relative weights are left to agency discretion, ${ }^{385}$ as in FIFRA, and judicial review of EPA's decisions uses the arbitrary, capricious standard. ${ }^{386}$ Testing is expensive, and industry has an interest in casting doubt on the validity of toxicity data generally. ${ }^{387}$ Whatever standard TSCA adopts, therefore, industry has a strong incentive to litigate the imposition of test rules. But Congress should try to limit delay and litigation. The changes suggested above, adopted either individually or together, should improve TSCA's efficiency.

\section{TSCA as an Information Resource}

The usefulness of the TSCA model can be extended to toxic substances regulation generally. TSCA was intended to remedy the balkanization of the existing toxics statutes, to avoid overlap and duplication in information and regulation, and to maximize available information from all sources, old and new. ${ }^{388}$ As an umbrella for collecting, coordinating, and creating information, its coverage and variety of information-acquisition techniques has the potential to be the vehicle for supplying data to other regulatory programs, either directly or through TSCA's contributions to generally available databases. ${ }^{389}$ Moreover, while EPA has yet to develop a coordinated information strategy even within the section 4 program, ${ }^{390}$ it could use TSCA to give direction to a federal toxic substances information policy. The enactment of TSCA was roughly contemporaneous with various efforts to coordinate the federal carcinogen policy, most notably the Interagency

384. S. Rep. No. 848, supra note 63 , at 28 ; see also United States v. Wade, 577 F. Supp. 1326, 1340 (E.D. Pa. 1983) (finding that language vests great deal of discretion in agency).

385. 126 Cong. Rec. 31,967 (1980) (remarks of Rep. Florio) (stating that EPA's authority to establish reportable quantities will "take into account relevant factors so that reportable quantities . . . will bear a direct relationship to presenting 'substantial danger" ").

386. 42 U.S.C. $\S 9613(\mathrm{j})(2)(1988)$.

387. See Lyndon, Information Economics, supra note 6, at 1820 \& n.92.

388. See S. Rep. No. 698, supra note 72, at 23, reprinted in 1976 U.S. Code Cong. \& Admin. News at 4513. One commentator charges that EPA has instead used TSCA to avoid taking regulatory action by referring to other agencies. Ruggerio, Referral of Toxic Chemical Regulation Under the Toxic Substances Control Act: EPA's Administrative Dumping Ground, 17 B.C. Envtl. Aff. L. Rev. 75, 77 (1989). In at least one instance, EPA has withdrawn a test rule to transfer the matter to OSHA. See EPA, Toluenediamines; Termination of Investigation Concerned with Occupational Exposure, 51 Fed. Reg. 25,070, 25,071 (1986). Since EPA regularly bases test rules on workplace exposure (the notice concedes that it is a matter of "policy" and "appropriate[ness]," and not a legal barrier), this action can only be seen as an unnecessary scattering of information.

389. See Hayes, Sleeping Giant, supra note 9, at 3; Siegel, supra note 175, at 10,020 . The NTP performs this function for much non-EPA health research. U.S. Dep't of Health and Human Services, supra note 247, at 1-2.

390. See Chemical Testing Program, supra note 312, at 23-25. 
Regulatory liaison Group (IRLG), which was founded in 1977 and produced some influential quantitative risk assessment guidelines. ${ }^{391}$ EPA is now beginning to take some steps in this direction under TSCA. Section 8(a) data collection has already been used in aid of the Clean Air Act, ${ }^{392}$ and EPA requires industry to supply section 8 data in an elaborate generalized format, known as the Comprehensive Assessment Information Rule (CAIR), which was designed to facilitate use across many environmental statutes. ${ }^{393}$

Information gathering is what TSCA brings to toxic substances regulation. It provides almost every information acquisition technique available elsewhere, and it adds the virtually unique technique of test rules. Unlike FIFRA, TSCA authorizes their application to the great majority of substances of concern. By comparison, the informationgathering potential of the air, water, and solid waste acts are rudimentary, permitting little of the flexibility and power that EPA can deploy under TSCA. For instance, in a Clean Water Act investigation of allegations of illegal dumping of toxic substances, EPA needed to subpoena records and testimony. The Clean Water Act did not authorize subpoenas, so EPA turned to TSCA. ${ }^{394}$ The Ninth Circuit turned aside the facility's argument that EPA was using TSCA for an improper purpose, finding that the basis for independent TSCA action, though scant, was not nonexistent given TSCA's broad mandate. ${ }^{395}$

Test rules undoubtedly will be central to TSCA's new role. ATSDR uses the testing programs of TSCA and FIFRA to compile its toxicology profiles and health assessments. ${ }^{396}$ Requirements to test are also helpful in financing ATSDR's work, as Congress intended. ${ }^{397} \mathrm{Re}-$ cently, EPA promulgated test rules for the express and sole purpose of

391. See Merrill, supra note 3, at $464-65$ \& n.8; Scientific Bases, supra note 10 , at 39,858 .

392. See EPA, Chemical Information Rules; Addition of Chemicals, 53 Fed. Reg. 10,387 (1988) (to be codified at 40 C.F.R. $\$ 712.30$ ). See supra text accompanying notes 231-233.

393. EPA, Comprehensive Assessment Information Rule [CAIR], 53 Fed. Reg. $51,698,51,698-99$ (1988) (to be codified at 40 C.F.R. pt. 704). The first CAIR was used to develop information needed by NIOSH and the EPA Air Office; section 8(d) has been used for the Water Office and CPSC. Hayes, Sleeping Giant, supra note 9, at 5.

394. 15 U.S.C. $\$ 2610$ (c) (1988).

395. In re EPA v. Alyeska Pipeline Serv. Co., 836 F.2d 443, 446-48 (9th Cir. 1988).

396. 42 U.S.C. \$ 9604(i)(3), (6)(F) (1988); H.R. Conf. Rep. No. 962, supra note 56, at 212, reprinted in 1986 U.S. Code Cong. \& Admin. News at 3305; H.R. Rep. No. 253, supra note 195, pt. 5, at 30, reprinted in 1986 U.S. Code Cong. \& Admin. News at 3153.

397. 42 U.S.C. $\$ 9604(\mathrm{i})(5)(D)$ (1988). However, ATSDR has "not actively pursued" this issue, Siegel, supra note 175, at 10,014, and the new National Contingency Plan still places primary reliance on the cumbersome CERCLA cost recovery process to obtain payment, EPA, National Oil and Hazardous Substances Pollution Contingency Plan, 53 Fed. Reg. 51,394, 51,402 (1988) (to be codified at 40 C.F.R. pt. 300) (preamble to proposed plan Dec. 21, 1988). 
obtaining information for RCRA.398 As early as 1978 CPSC had announced that it would request that EPA require manufacturers to provide test data under TSCA; 399 twelve years later, such a rule was proposed. ${ }^{400}$ Moreover, data requests under TSCA can be organized independently of statutory categories, for example, by concentrating on chemicals with multimedia exposure, ${ }^{401}$ on particular hazardous waste sites, ${ }^{402}$ or other categories.

This role for TSCA, and for section 4 in particular, is unquestionably consistent with the statute's structure and purpose. Responding to industry objections that it was improperly using TSCA to collect information for a RCRA program, EPA explained:

TSCA was enacted in 1976 to fill in some of the regulatory gaps that then existed regarding the assessment and prevention of adverse health and environmental effects from potentially toxic substances. This test rule therefore fulfills the intent of Congress, because RCRA contains such a "regulatory gap": it does not itself contain any analogous authority to TSCA that would permit the Administrator to require testing of chemicals. ${ }^{403}$

The potential of TSGA requirements to test are enormous, and EPA has only begun to tap their potential.

\section{Conclusion}

Evaluation of any regulatory scheme must consider the importance and cost of information in a given context, whether the effects of uncertainty are desirable or undesirable, how regulatory standards might improve or worsen the effects of an information deficit, and what steps can be taken to develop needed data. Toxic substances regulation exemplifies the effects of information, and its absence, on regulatory pol-

398. See EPA, Office of Solid Waste Chemicals; Final Test Rule, supra note 303, at 22,302 .

399. See CPSC, Classifying, Evaluating, and Regulating Carcinogens in Consumer Products: Interim Statement of Policy and Procedure, 43 Fed. Reg. 25,658, 25,665 n.6 (1978). The Interim Statement was subsequently overturned on procedural grounds and not renewed. See Dow Chem. v. Consumer Prod. Safety Comm'n, 459 F. Supp. 378 (W.D. La. 1978), aff'd on rehearing, 464 F. Supp. 904 (W.D. La. 1979).

400. See EPA, N-Methylpyrrolidone; Proposed Test Rule, 55 Fed. Reg. 11,398, 11,398 (1990).

401. See, e.g., EPA, Proposed Prohibition of Hexavalent Chromium Chemicals in Comfort Cooling Towers, 53 Fed. Reg. 10,206, 10,207 (1988) (to be codified at 40 C.F.R. pt. 749) (proposed Mar. 29, 1988) (regulatory action under §6); Ginsburg, TCSA's Unfulfilled Mandate for Comprehensive Regulation of Toxic Substances: The Potential of TSCA $\S 21$ Citizens' Petitions, 16 Envtl. L. Rep. (Envtl. L. lnst.) 10,330, 10,330-31 (1986).

402. See Ginsburg, supra note 401, at 10,331-32.

403. EPA, Office of Solid Waste Chemicals; Final Test Rule, supra note 303, at 22,302; see also H.R. Rep. No. 1341, supra note 35, at 6-7 (discussing gap-filling role of TSCA). 
icy. The uncertain disease-inducing mechanism of toxic chemicals makes their effects difficult to determine. Hence, it is nearly impossible to establish a level of regulatory control with any confidence in its accuracy. Plausible responses to this uncertainty include developing surrogate standards or dispensing with certainty and accuracy as goals. Congress and EPA, however, have not chosen these approaches. Instead, Congress has adopted the unreasonable risk standard, and EPA has continued to seek accuracy through the quantitative risk assessment methodology. Unfortunately, both the standard and its corollary methodology are extremely information-intensive. Thus, the underlying regulatory scheme does not so much confront the data gap as widen it.

Although revision of the unreasonable risk regime would reduce data needs, the regulatory process still has basic information demands that cannot be avoided. Standard setting, the locus of unreasonable risk and quantitative risk assessiment, accounts for only part, albeit a large part, of the data gap. Accordingly, environmental law must seek ways to acquire the needed data. Congress and EPA, mindful of these information needs, have provided several types of regulatory techniques for acquiring the necessary data. Each of the traditional methods-compilations of existing data; recordkeeping, monitoring, and inspection; government research; and licensing-is useful, indeed vital. But none will close the data gap.

TSCA's requirement to test shows great promise for narrowing the data gap. It has many of the virtues of the traditional techniques and relatively few of their drawbacks. Moreover, a number of modest changes to simplify test rule standards and procedures would make them considerably more effective than they have been to date. By making greater use of TSCA test rules, in conjunction with the full range of information-gathering techniques available under TSCA and the other toxics statutes, EPA can establish a solid foundation for a sound regulatory information policy. 